\title{
The role of social capital in adoption of sustainable practices in Chile and Indonesia
}

\author{
Dissertation \\ to obtain the Ph. D. degree \\ in the International Ph. D. Program for Agricultural Sciences in Goettingen (IPAG) \\ at the Faculty of Agricultural Sciences, \\ Georg-August-University Göttingen, Germany
}

presented by

Gracia María Lanza Castillo

born in Tegucigalpa, Honduras

Göttingen, June $2^{\text {th }} 2021$ 

D7

Name of supervisor: Prof. Dr. Meike Wollni

Name of co-supervisor: Prof. Maria Alejandra Engler Palma, PhD

Member of Examination Committee: Prof. Marcela Ibañez Diaz, Ph.D.

Date of dissertation: 24.01 .2018 
An meinen Mann Enrique, meine Söhne Enrique und Raúl und meinen Vater Mario Lanza (RIP) 


\section{Summary}

The world food and non-food needs are expected to increase from 2005/2007 to 2050 by 60 percent, raising concerns on how this demand will be fulfilled sustainably (Le Mouël and Forslund, 2017). To cope with this increase in demand, the agricultural sector faces an essential decision between land sparing and land sharing, a debate particularly active in the last decade (Alexandratos et al., 2012; Harrison, 2002; Le Mouël and Forslund, 2017; TheRoyal Society (London), 2009). On the one hand, central elements of the debate concern the effects of agricultural intensity (or yield) on biodiversity, while land-sharing integrates nature conservation approaches into agricultural production across a region but characterized by low-yielding farmland with higher biodiversity, but with less land available for the sole purpose of nature conservation. The increase of agricultural land is of particular attention because it expands through the alteration of forests, swamplands, and other pristine habitats (Barbier, 2004). On the other hand, land-use change to expand agriculture increases Greenhouse Gas (GHG) emissions and is accountable for $12-17 \%$ of the total global GHG emissions, negatively impacting biodiversity and ecosystem services (Hamilton et al., 2015; Pradhan et al., 2015).

On the other hand, an increase of yields requires an increase in production which will be constrained by the finite resources provided by Earth's land, oceans, and atmosphere (Godfray et al., 2010); therefore, producing more food from the same area of land while reducing negative environmental externalities, can be accomplished by the use of existing sustainable practices (FAO, 2011; Godfray et al., 2010; Jordan, 2015; Tubiello et al., 2014). Farmers' decisions regarding adopting agricultural practices are based on pre-existing networks, organizations, and other relationships among individuals (Ostrom and Ahn, 2003). Although adoption has been widely studied, it shows a disciplinary fragmentation (Pannell et al., 2006). Social capital is a concept that helps integrate with the economic analysis of communities' cultural, social, and institutional dynamics. Social capital is a mechanism that helps to overcome market imperfections and promotes collective action, generating positive externalities that facilitate cooperation to achieve goals. Still, it can also have a negative side (Ostrom, 2007). This dissertation aims to analyze the role of social capital through two case studies; one, which analyses how social capital and its interaction with psychological 
constructs affects the decision to adopt pressurized irrigation systems using a cross-sectional survey. The second case study focuses on social capital and incentives effects on pro-social behavior, especially looking at land allocated for the cultivation of rubber agroforestry in Indonesia under individual and collective Payment for Environmental Services (PES) schemes applying a framed-field experiment.

Results show that social capital plays an important role in adopting sustainable practices in the agricultural sector. On the one hand, we provide empirical evidence about the significant and positive influence of social capital variables on the level of perceived control and intention to perform the adoption of pressurized irrigation. On the other, we show that social capital, in the form of a network, could negatively influence conservation behavior when the social norm is to cultivate the more profitable crop, as in Indonesia's oil palm under PES schemes. We find that individuals were more susceptible to social capital variables under collective schemes than in the individual scheme. Social capital in the form of a network shows a negative and significant influence on the share of land allocated to rubber agroforestry.

In contrast, membership and environmental awareness of the network have a positive influence. Individual characteristics such as individual environmental perception, land tenure, and if the participant cultivates rubber agroforestry were more relevant in the individual scheme. When comparing both case studies, the differences in the sign of the effect of social capital, precisely the effect of a social network, reaffirm the need to design context-specific strategies and consider each site's social dynamics. In addition, the results show that land heterogeneity matters; collective schemes may be especially suitable to engage large landowners, who may feel the moral pressure to contribute their share under such institutional arrangements. In contrast, smaller farmers respond to individual and collective incentives. However, it should be kept in mind that the effectiveness of PES is highly place-specific and depends on the social norms prevalent in the communities.

Our empirical results have important policy implications. In the case study from Chile, we identified that attitude campaigns are not enough to influence intentions. The government could target and change the norm of superficial irrigation by convincing people of core beliefs associated with water conservation awareness and boost farmers' trust in water organizations that could foster cooperation to adopt pressurized irrigation systems as a norm. In the case study in Indonesia regarding Payment for Environmental Services, our findings have important implications for REDD focus countries, which is the most crucial arena for collective PES nowadays. Policymakers can build upon existing social norms; provide economic incentives 
for conservation, and complement informal institutions. Future PES should focus and be tailored to the participants' characteristics in terms of endowment and should have a better understanding of the social norms of the context. 


\section{Acknowledgment}

I would like to express my sincere gratitude to my supervisors, Prof. Dr. Meike Wollni, Prof. Alejandra Engler and Prof. Marcela Ibañez, their advice, guidance and patience was fundamental to achieve this goal. Thank you. I have learned a lot from you and thanks for being mentors in this learning process. I admire you and you are my leading example.

I would like to thank my husband, Enrique for his support, trust and for encourage me to undertake this challenge; thanks for getting this adventure started my love. Thanks to my kids Enrique and Raul for their patience and for keep me moving forward.

I would like to express my appreciation to several institutions that support my family and me in many different ways.

- Thanks to the Graduate School of Social Sciences (GGG) for your support in the last stage of this dissertation.

- Thanks to the Katholisher Akademisher Auslander Dienst (KAAD) for its spiritual, emotional and financial support, thanks for believing in me and helping me fulfill this dream.

- Thanks to the University of Talca for getting this process started and their leadership on implementing the instruments on the ground.

- Thanks to the International Office from Gottingen University, Simit Wahdat, thanks for having your door always open.

Thanks to Grete Thinggaard and Sebastian Lakner for your continuous support.

Thanks to my colleagues from the chair, especially to Miriam, Denise, Katrin, Astrid and Jessica for listening.

Thanks to my dad, Mario who is watching from heaven. Thanks to my mom, Sofia, my brother Marito and my sister Alex for their support from Honduras. 


\section{Table of Contents}

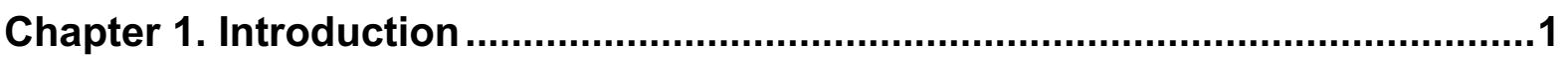

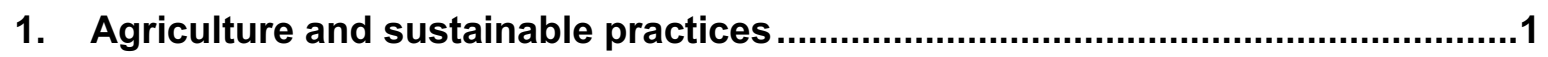

2. Conceptual framework ...................................................................................

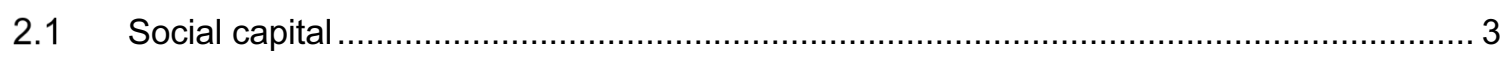

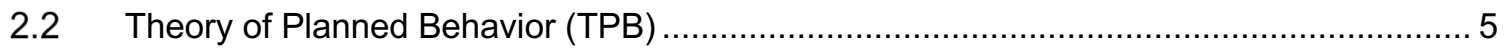

2.3 Payment for Environmental Services (PES) ........................................................ 7

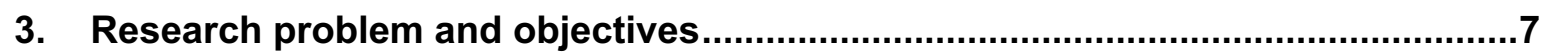

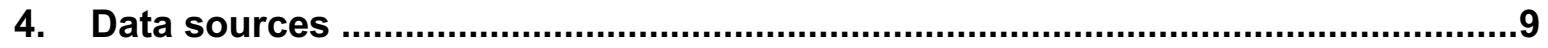

$4.1 \quad$ Cross-sectional Survey in the Maule Region in Chile ................................................ 9

4.2 Frame field experiment in the Jambi Province in Indonesia ........................................ 10

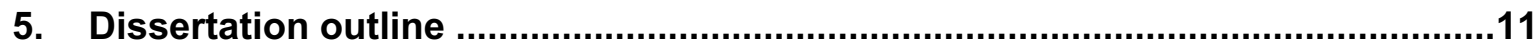

Chapter 2. Planned behavior and social capital: Understanding farmers' behavior toward pressurized irrigation technologies?....................................13

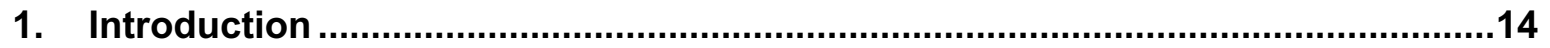

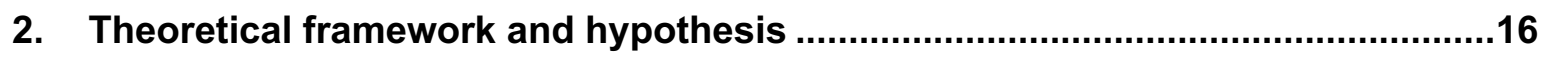

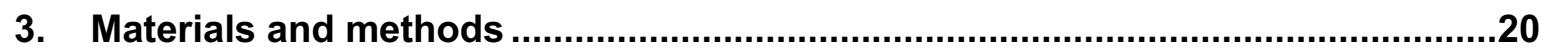

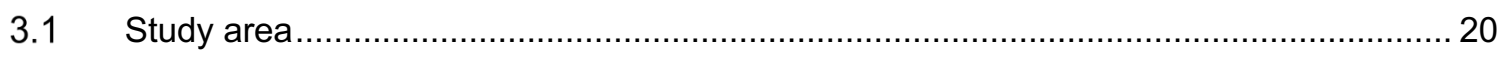

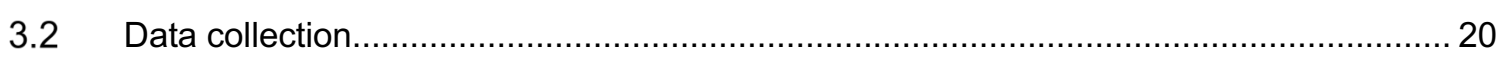

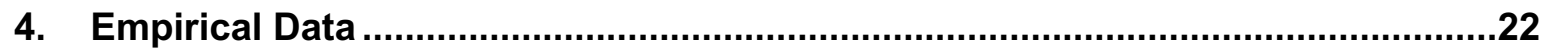

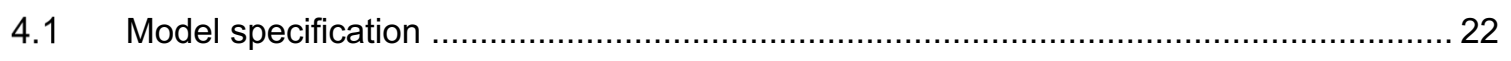

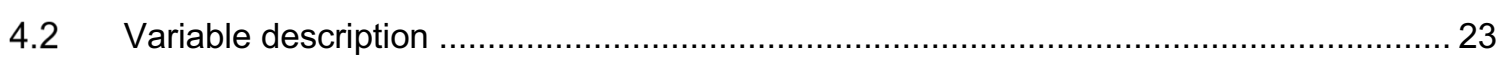

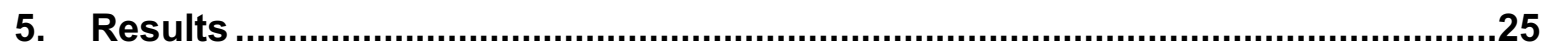

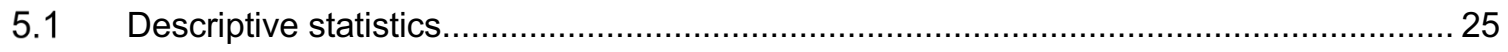

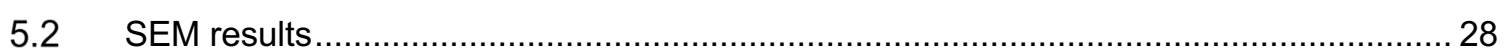

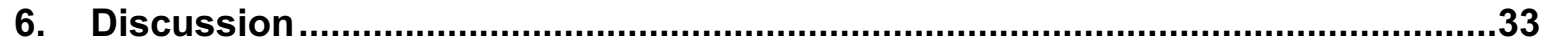

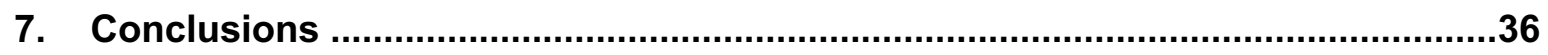


Chapter 3. Social capital and conservation under collective and individual incentive schemes: a framed field experiment in Indonesia...............................38

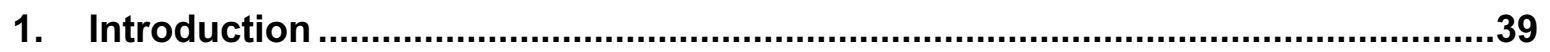

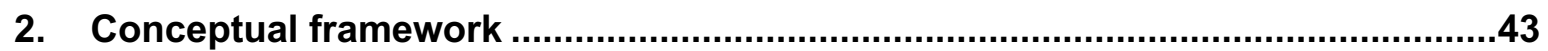

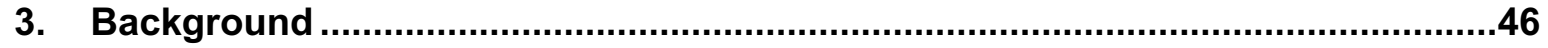

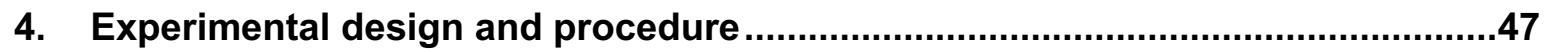

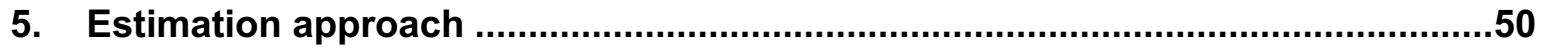

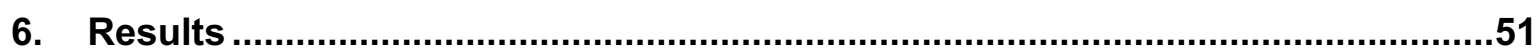

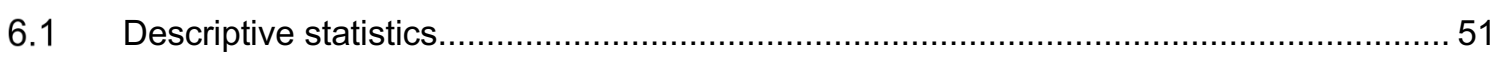

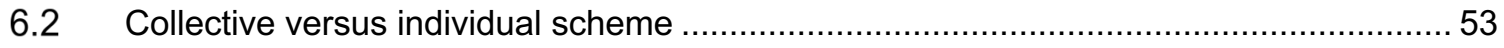

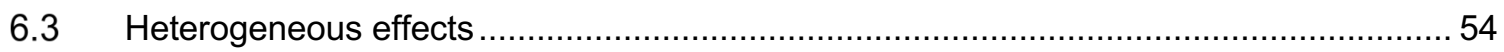

6.4 PES interaction with social norm and network characteristics .................................. 56

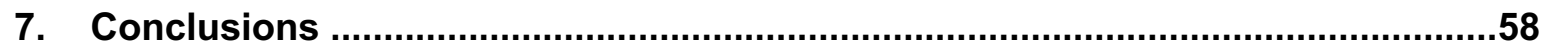

Chapter 4. Concluding remarks ......................................................................60

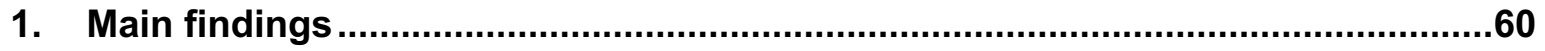

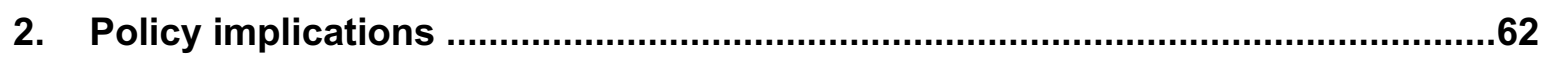

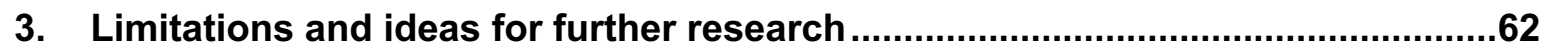

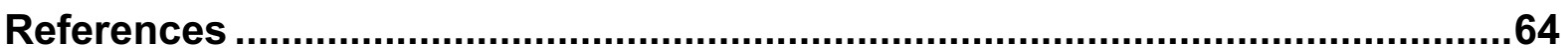

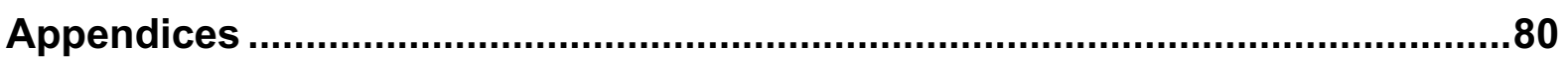




\section{List of tables}

Table 1. Descriptive Statistics baseline data (Standard deviation in parenthesis) ...............25

Table 2. Standardized regression coefficients (Standard errors in parenthesis) ..................30

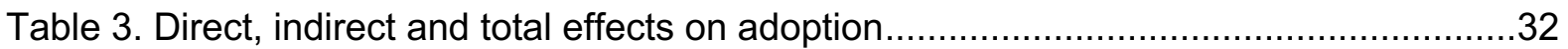

Table 4. Parameters used and participants in the experiment by treatment and endowment

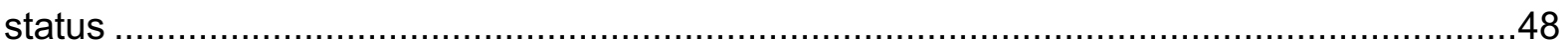

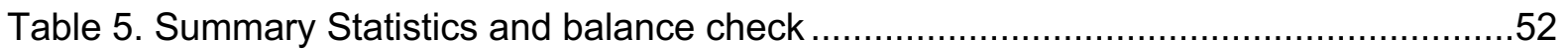

Table 6. Random effects GLS estimation for share of land conserved at the group level .....53

Table 7. Random effect GLS estimation of individual share of land allocated to rubber agroforestry

Table 8. Random effect GLS estimation of individual share of land allocated to rubber agroforestry .56

Table 9. Standardized regression coefficients of the relationships for the statements of the continuous latent variables .81

\section{List of figures}

Figure 1. Theory of Planned Behavior (Ajzen, 1991)

Figure 1. Theory of Planned Behavior (TPB) and social capital - a socio-psychological model 18

Figure 3. Mean group share allocated to conservation Error! Bookmark not defined. 


\section{List of appendices}

Appendix 1. The SEM input (Mplus 7) - Integral model (TPB, social capital and control variables) .80

Appendix 2. Items for Latent variables creation. .81

Appendix 3. Survey - Adoption of irrigation technologies by small farmers in the Maule and O'Higgins Region. The role of social capital 83

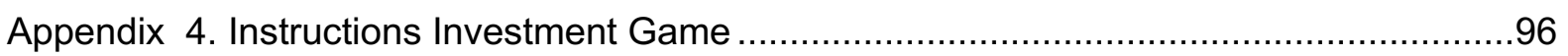

Appendix 5. Post Experimental Survey - Indonesia ......................................................113

Appendix 6. General Household Survey - Indonesia .....................................................118

Appendix 7. Payoff table, per treatment and per endowment.......................................126

Appendix 8. Correlation among social capital variables ...................................................129 


\section{Chapter 1. Introduction}

\section{Agriculture and sustainable practices}

The world food and non-food needs are expected to increase from 2005/2007 to 2050 by 60 percent, rising concerns on how this demand will be fulfilled sustainably (Le Mouël and Forslund, 2017). In order to cope with this increase in demand, the agricultural sector faces an essential decision between land sparing and land sharing, a debate particularly active in the last decade (Alexandratos et al., 2012; Harrison, 2002; Le Mouël and Forslund, 2017; TheRoyal Society (London), 2009). In one hand, central elements of the debate concern the effects of agricultural intensity (or yield) on biodiversity, while land sharing integrates nature conservation approaches into agricultural production across a region but characterized by lowyielding farmland with higher biodiversity, but with less land available for the sole purpose of nature conservation. The increase of agricultural land is of special attention because it expands through alteration of forests, swamplands and other pristine habitats (Barbier, 2004). Land use change to expand agriculture increases Greenhouse Gas (GHG) emissions, accountable for $12-17 \%$ of the total global GHG emissions, and impact negatively biodiversity and ecosystem services (Hamilton et al., 2015; Pradhan et al., 2015). In the other hand, increase of yields requires an increase in production which will be constrained by the finite resources provided by Earth's land, oceans and atmosphere (Godfray et al., 2010); therefore, producing more food from the same area of land while reducing negative environmental externalities, can be accomplish by the use of existing sustainable practices (FAO, 2011; Godfray et al., 2010; Jordan, 2015; Tubiello et al., 2014).

Sustainable practices aim to assure that farmers can receive a fair level of income, while protecting the environment and keeping their families and communities stable (Fazio et al., 2017). Sustainable practices include a wide range of activities at the farm level such as: rotation of crops or development of agroforestry systems that help maintain soil fertility; efficient water management; natural resources management; reduction on input reliance (mineral fertilizers and chemical pesticides), among others (Lee, 2005; Nations, 1995). Specifically with regards to water resources, agriculture accounts for about $70 \%$ of the total freshwater withdrawals globally and for over $90 \%$ in the majority of least developed countries (LDC)(UNESCO, 2016); an increase in demand by the agricultural sector will imply 
competition with the domestic, energy and manufacturing sector (AQUASTAT, 2014). In this sense, adoption of drip irrigation or pressurized irrigation systems provides better control on the amount of applied water and better irrigation uniformity. (Battikhi and Abu-Hammad, 1994) compared efficiencies of surface and pressurized irrigation systems showing levels of efficiency of $53 \%$ and $70 \%$ respectively. In general, sustainable practices are being promoted because they have been proven to be effective to increase production and reduce negative environmental impacts (Bullock, 1992; Letey et al., 1990; Playán and Mateos, 2006; Snapp et al., 2005; Tilman, 1999; Tilman et al., 2002), yet adoption rates are still low. Pretty and Hine (2001) reported that from the total farmland in Africa, Asia and Latin America only $3 \%$ have adopted sustainable practices. Several challenges have to be faced in order to increase adoption rates of sustainable practices by farmers whose management choices affect services linked to water, soil, climate and wild species (Hamilton et al., 2015). Choices are based in pre-existing networks, organizations and other relationship among individuals (Ostrom and Ahn, 2003). Social capital is a concept that integrates cultural, social and institutional dynamics of communities. Social capital is a characteristic of individuals and of their relationships, it is generated through social relationships resulting from exchanges among members involved in an organization (Islam et al., 2006). Social capital can generate positive externalities but it also can generate negative externalities for others. There is a gap in the literature with regards to the effect of social capital on cognitive constructs that affect the process of decision-making, as well as the role of social capital in pro-social behavior when providing incentives. This is of special importance because social capital generates positive externalities that facilitates cooperation for the achievement of goals but it can also have a negative side (Ostrom, 2007).

The aim of this dissertation is to analyze the role of social capital through two case studies; one, which analyses how social capital and its interaction with psychological constructs affects the decision to adopt pressurized irrigation systems. The second case study focuses on the effect of social capital and incentives on pro-social behavior specially looking at adoption of rubber agroforestry in Indonesia.

\section{Conceptual framework}

Several studies have identified that adoption is constrained by socioeconomic characteristics, economic factors, education and information, and land tenure (Baumgart-Getz et al., 2012; Fazio et al., 2017; Feder et al., 1985; Pannell et al., 2006; Prokopy et al., 2008; Shiferaw et 
al., 2009). Although, adoption has been widely studied it shows a disciplinary fragmentation (Pannell et al., 2006). In economics, adoption behavior is modeled as a decision made by perfectly rational agents (Lecouteux, 2013). In psychology, behavior is modeled based on the influence of cognitive constructs, being the Theory of Planned Behavior (TPB) the most commonly used to predict behavior (Ajzen, 2015, 2011, 2002, 1985). TPB proposes that behavior is predicted from intention and this from attitudes, perceived control and subjective norms (Lynne et al., 1995). Experimental economics have rejected the selfishness assumption that individuals could not achieved join benefits when left by themselves if everyone would benefit whether or not they contribute to the effort and proposed social capital as a concept that exchanges trust among people and therefore breed cooperation among individuals. Although each discipline have identified constraints that have been removed on specific cases, generally it is observed that immediate and uniform adoption in agriculture is rare (Feder et al., 1985).

\subsection{Social capital}

Economic research incorporates the concept of social capital to integrate the cultural, social and institutional dynamics of communities. Research includes the three forms of social capital: network, trustworthiness and formal and informal rules of institutions (Hawkins, 2007; Ostrom, 2007). Social network is seen as a mechanism that could help overcome market imperfections as it is a means to access information, acquire financing, safeguard against unexpected catastrophes, reduce information asymmetries and enforce contracts (Di Falco et al., 2011; Maertens and Barrett, 2013). When networks are well-established individuals can draw on ideas and experiences and compare the ethics of others (Pelling and High, 2005; Putnam, 1993). Membership is a key important element for networking; it provides benefits in terms of access to financing or cooperative loans. When individuals are attached to an organization they share common values and codes of behavior (social norms) generating places to replicate knowledge and exchange information (Grootaert, 1999). Although a member of a network may only know a small number of other members, he has access in turn to the networks and communities of these associates. These connections can lie dormant until some change in the requirements of the individual encourages a search for new information or other forms of support (Pelling and High, 2005). However, Maertens et.al. (2013) highlights that the literature related to the role of social networks remain underdeveloped as more research needs to be done to relax the assumption that social interactions reflect learning, as well as more detail data collection on individual subjective beliefs about different technologies and their traits, among others. 
Trust is a social tie that makes that common knowledge plays a self-enforcing agreement between two parties; it facilitates efficient contractual relations, reduce transaction cost in an imperfect market and allows adaptation to unexpected contingencies in an optimal way for the parties (Coleman, 1988; Lorenz, 2000). For example, Coleman (1988) shows that a group with an extensive trustworthiness can accomplish more and that repeated interaction fosters individuals to build a reputation of being trustworthy.

Institutions - formal and informal rules are a form of social capital, they are the guidelines of the game that people develop (Ostrom and Ahn, 2003). Social norms are informal rules shared and respected by other people in order to be partially sustained and enforced by the general community (Elster, 1989). Social norms are specially important because they arise when markets cannot be easily established, transactions costs are high and when the actions have external effects (Coleman, 1988, 1987). Elster (1989) identified norms of reciprocity, work norms, norms of cooperation as examples of social norms. In this study we will focus on norms of reciprocity. Norms of reciprocity is a type of social norm (Putnam, 1993), which measures individuals' knowledge sharing propensity capturing the extent to which farmers see themselves as providing value to their organization through their knowledge sharing (Putnam, 1993; Rouxel et al., 2015; Villalonga-Olives and Kawachi, 2015). The presence of social norms increase the levels of satisfaction, their absence allows individuals to achieve greater satisfaction from their own actions, but leaves them with less satisfaction overall, as they suffered from unconstrained action of others (Coleman, 1987). Norms are expectation about actions, and this is particularly important when analyzing technology adoption or pro social behavior, because the effect might not always be positive. As Ostrom (2003) underlines, there is a dark side of social capital when a smaller group leading to high benefits for those involved generates negative externalities for others.

Social capital includes more individualistic behavioral dispositions (i.e. trust, reciprocity, social skills and macro-institutional quality measures) (Woolcock, 2001). The three forms of social capital increased trust among the community. For instance, the trust among network members is a honorable resource that enables certain actions for the farmer and creates incentives to behave in a trustworthy manner (Putnam, 1993; Villalonga-Olives and Kawachi, 2015).

In addition to social capital, here we present the conceptual framework of the Theory of Planned Behavior used jointly with social capital to analyze adoption of pressurized irrigation 
in Chapter 2. Then we present Payment for Environmental Services as the framework of the framed field experiment of Chapter 3.

\subsection{Theory of Planned Behavior (TPB)}

TPB is based on the Theory of Reasoned Action (TRA) first proposed by Fishbein and Ajzen in 1967 (Fishbein and Ajzen, 2011), TRA suggested that under volitional control, behavior can be predicted from individual beliefs with regards to norms, control and behavioral beliefs which are channeled through attitudes, subjective norms and perceived control. These three core unobserved variables create the intention to perform an specific behavior and intention alone, under complete volitional control, predict actual behavior. Volitional control is understood as the extend of control that the individual has over an specific behavior (Glanz et al., 2008). Ajzen (1985) expands TRA and includes perceived behavioral control to consider those key aspects that are beyond individual control but that affect directly the intention and actual behavior (Figure 1, Ajzen, 2003).

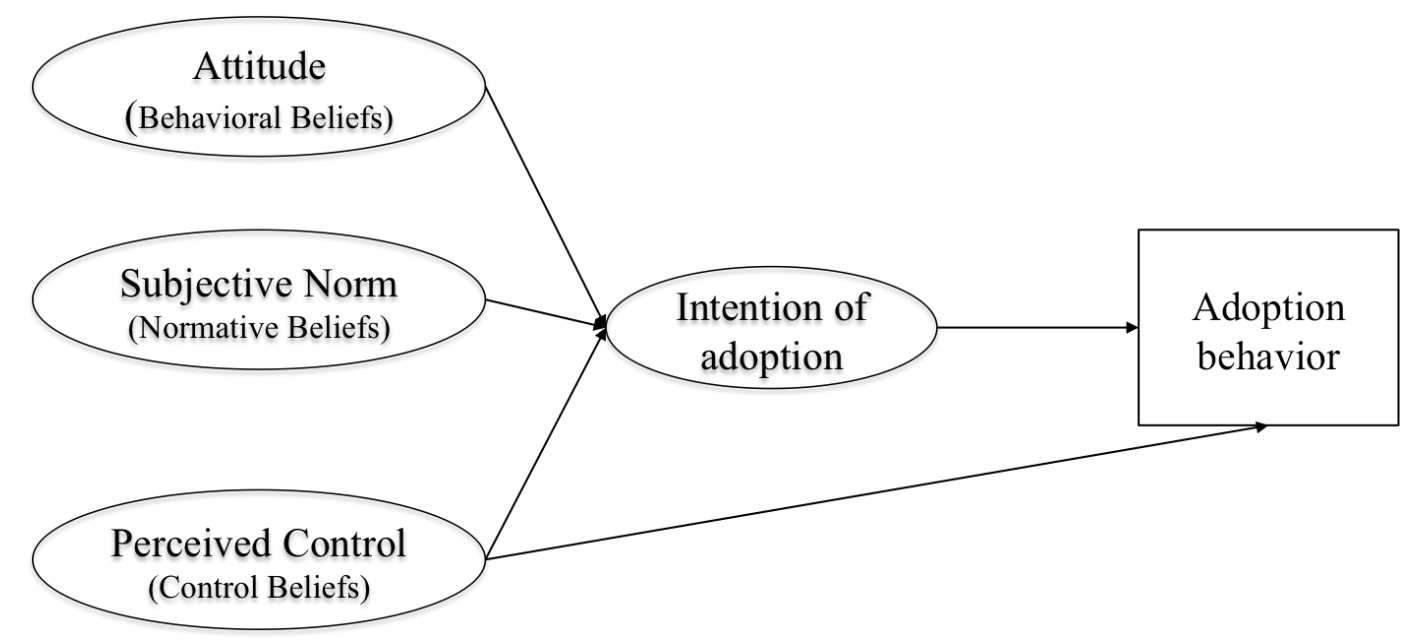

Figure 1. Theory of Planned Behavior (Ajzen, 1991)

TPB comprises four unobserved cognitive constructs: attitudes, subjective norms and perceived control to create intention. To measure attitudes, information with regards to individual beliefs towards the usefulness of the behavior, and the level of difficulty/easiness is gathered. These beliefs weighed by the appraisal of the outcome of the action define the Attitude. Individuals with strong beliefs or perception about the positive outcome of an action will have a positive attitudes, and the contrary applies when the perception is strongly negative 
(Glanz et al., 2008). To measure subjective norms, information with regards to what extend the individual is concerned to comply with others (family or close friends) approval or disapproval. Individuals who give high weight to their network expectation are more likely to feel positive about having the intention and changing their behavior, while those whose belief is that by performing the behavior they will be disapprove socially then will have a lower subjective norm, intention and will be less prompt to change their behavior (Conner and Armitage, 1998).

The third important element of TPB is perceived control, which incorporates aspects that are beyond the motivation of the individual. This concept is used exchangeable with the concept of self-efficacy as it measures the extent to which the farmers feels confident, with the abilities required to perform the behavior. This predictor becomes more relevant when the individual has low volitional control, and when it is a close measurement of actual control; in this scenario, perceived control and intention have a direct effect on actual behavior (Madden, Ellen, and Ajzen, 1992). When volitional control is high, then, the effect of perceived control is mediated through intention. TPB emphasize that perceived control, if measured properly, can serve as strong proxy for actual behavior, Nonetheless, there are behaviors that require high investment cost, such as pressurized irrigation systems, that even when the measurement of perceived control is appropriate, it is not a good proxy for actual control, because the behavior will not be perform even if the individual has a strong intention and high perceived control. Success in performing the behavior relies not only on a positive intention but also on an adequate level of behavioral control (Ajzen, 2002).

TPB postulate a theoretical framework that allows policy-makers to identify those beliefs that are constraining change on behavior. The weights of attitudes, subjective norms and perceived control in determining intentions vary for different behaviors and populations. TPB and TRA have been widely implemented in the health sector; for example, it has been used to analyze decisions to exercise after an open-heart operation, or the behavior after having the intention to quit smoking. TPB has offered key elements to increase the success of strategies in the health sector in order to influence the beliefs towards an specific behavior (Ajzen and Fishbein, 2005). The TPB model has also been extended to include other determinants of intention, like self-identity (Pelling and High, 2005), self-efficacy (Conner and Armitage, 1998) or moral norm (Yazdanpanah et al., 2014a). In agriculture, specifically when analyzing technology adoption, researchers used the direct measure of perceived control instead of a direct measure of control (Ajzen 2002). 


\subsection{Payment for Environmental Services (PES)}

PES have been praised as a more flexible and effective instrument to facilitate protection of public ecosystem services as compared to those based on regulation (Ingram and Hong, 2011; Narloch et al., 2012; Pagiola et al., 2005; Porras and International Institute for Environment and Development., 2010). PES is a market-based approach to conservation based on the twin principles that those who benefit from environmental services (such as users of clean water) should compensate those who voluntarily provide the services (or enhancing them) relative to a given baseline (Wunder and Borner, 2011, Wunder, 2005; Pagiola and Platais, 2007). The development of PES programs on agricultural lands is receiving attention in developing countries (Branca et al., 2011; FAO, 2007b; MA,2005; Ribaudoetal.,2010) as changes in agricultural land use strategies and production technologies can potentially enhance positive or negative environmental externalities (Ingram and Hong, 2011). The main goal of PES ought to be the creation of incentives for the provision of such goods, thereby changing individual or collective behavior that otherwise would lead to excessive deterioration of ecosystems and natural resources. Therefore, it may be convenient to define PES as a transfer of resources between social actors, which aims to create incentives to align individual and/or collective land use decisions with the social interest in the management of natural resources (Muradian et al., 2010a). Given these potential goals for PES policies, the likelihood of success depends on the design characteristics of a PES scheme and the context in which it is implemented.

\section{Research problem and objectives}

As mentioned above, the aim of this dissertation is to understand the role of social capital on adoption of sustainable practices. Specifically, we focus on conservation behavior towards adoption of two sustainable practices:

1) Pressurized irrigation systems that improve water efficiency (Chapter 2).

Agriculture is the highest consumer of freshwater globally (FAO, 2011). Despite all efforts to promote highly efficient water conservation technologies in the agricultural sector, adoption rates are still very low. Worldwide there are 324 million hectares equipped for irrigation from which $86 \%$ uses surface irrigation, $11 \%$ uses sprinkler irrigation but only $3 \%$ has adopted localized irrigation which has high levels of efficiency (AQUASTAT, 2014). Water is limited and demand is increasing rapidly from other sectors such as the manufacturing, domestic and 
energy constraining water availability for irrigation in agriculture (Hearne and Easter, 1997; Rosegrant et al., 2000; Tran et al., 2016). Water conservation technologies play a key role facing current and future challenges due to climate change and population growth, they can achieve water savings from 30-60\% and increases in yield by $20-50 \%$ (Darouich et al., 2014; Postel, 2000; van der Kooij et al., 2013).

The specific research objectives of this chapter are:

- To provide empirical evidence on how farmers' attitude, subjective norms and perceived control influence intention and actual adoption of modern irrigation technology, measured 12 months after the stated intention.

- To gain an in-depth understanding on what is affecting farmers' attitude, subjective norms and perceived control. We propose the use of social capital to capture how beliefs are formed and understand the key constructs of TPB (attitude, subjective norms and perceived control) as they provide the framework within which farmers' intentions are formed.

This study fills two gaps. First, we assess intention and the revealed behavior of adoption after 12 months. Second, we explicitly consider social capital (trust, network and membership) and control variables (access to extension services, water price, physical capital (ha), education and experience) that influence adoption, providing a more thorough understanding and a broader conceptualization.

2) Rubber agroforestry systems that improve biological habitats, soil conservation, among others (Chapter 3 ).

Indonesia spreads over more than 18,000 islands with high levels of endemic species and rich biodiversity. Oil palm plantations cover approximately 8 million hectares in Indonesia and it is expected that they will reach about 13 million hectares by 2020 (Cacho et al., 2014). The establishment of oil palm and timber plantations have now become the main drivers of deforestation in Indonesia (Cacho et al., 2014; Koh and Wilcove, 2008). Much of the production in Indonesia comes from large-scale plantations, however, independent smallholders are increasing their share and may dominate production in the future.

In order to reduce the pressure on the forest, Payment for Environmental Services (PES) are regarded as a promising policy instrument to foster conservation and promote alternative 
agroforestry systems such as rubber agroforest. Although rubber agroforest can rapidly develop a vegetation structure close to that of secondary forest of similar age (Ekadinata et al., 2004) it is less profitable than oil palm plantations and therefore the cultivation of rubber agroforestry systems needs to be incentivize through PES schemes.

PES reduce deforestation rates, although the effect is relatively modest (Samii et al., 2014). One concern that remains is that the functional value of a reserve for biodiversity conservation usually depends on its spatial configuration (Poiani et al., 2000). Individual payments do not explicitly promote the coordination among suppliers to conserve potentially resulting in lower ecological services. An alternative to overcome this problem is to use a collective incentive scheme, where individual service providers receive a payment only if a minimum level of conservation is achieved at the group level (Kerr et al., 2014; Dickman et al., 2011). However, in collective schemes uncertainty on whether the threshold can be trespassed and the possibility for free-riding behavior might decrease the effectiveness of this instrument compared to an individual payment scheme.

The specific research objectives of this chapter are:

- To investigate the effectiveness of individual versus collective payments in promoting conservation using a framed field experiment.

- To assess the response to two payment levels (low and high) and

- To disentangle heterogeneous effects to individual and collective schemes.

\section{Data sources}

This dissertation is based on two different data sources: cross sectional survey to analyze adoption of pressurized irrigation in Chile and a framed-field experiment to assess conservation behavior under individual and collective PES schemes in Indonesia.

\subsection{Cross-sectional Survey in the Maule Region in Chile}

The first case study was carried out in the Maule and O'Higgins regions of Chile. These regions contribute $14.9 \%$ of the agricultural gross domestic product (GDP), and $19 \%$ of the exports from agriculture in 2012 (ODEPA, 2013). Although the area's basic productive structure is intensive in input use, including water; water efficiency are among the lowest nationwide of about $23-30 \%$. The main agricultural production is concentrated in vineyards, which represent $40 \%$ of the total cultivated area in Chile, fruit (mainly apples, cherries and berries), and intensive annual crops like maize and rice. 
The study applied a cross-sectional survey. The targeted population was small and mediumscale vineyard producers and the sample size used in the study included 324 observations selected from 21 municipalities from the regions under study. All data was gathered applying a face-to-face questionnaire developed from a literature review, pre-pilot studies and previous in-depth interviews. Telephone follow-ups with 295 of the 324 participants $(91 \%$ response rate) were conducted 12 months after the baseline. This follow-up call verified short-term actual behavior and facilitated a comparison with intentions declared one year ago.

\subsection{Frame field experiment in the Jambi Province in Indonesia}

Harrison and List (2004) define 'framed field experiment' as an study that depart in a potentially important manner from typical laboratory studies because it is implemented in the field context in the commodity, task, stakes, or information set of the subjects. This type of experiment is important in the sense that a myriad of factors might influence behavior, and by progressing slowly towards the environment of ultimate interest one can learn about whether, and to what extent, such factors influence behavior in a case-by-case basis. In addition, by designing or manipulating real world markets, interesting economic phenomena can be explored(List, 2008). This method to elicit preferences is the most convenient as we want to analyze the effect of an external PES incentive to promote conservation behavior by cultivating rubber agroforestry.

For this we consider the Jambi province of Indonesia. Indonesia has the third largest area of tropical rainforest in the world after the Amazon and Congo Basins (Fitzherbert et al., 2008). Despite its reputation as a global biodiversity hotspot, it is estimated that $53 \%$ of the total oil palm planted area in Indonesia is the result of deforestation since 1989 (Vijay et al., 2016). In response, Indonesia is a focused country under the UNFCC for forest conservation and REDD+ development activities. This study therefore provides insights on the effect of different PES schemes to promote sustainable land use.

In the framed field experiment, participants decide how to allocate their endowment of land between two alternative products commonly grown in the region: rubber agroforestry and oil palm plantations. To examine how heterogeneity in endowments and in return affects conservation decisions, we vary the endowment of land that individuals in a group receive. Two individuals are low endowed and receive 5 units of land and one individual is high 
endowed and receives 10 units. The incentive was framed as Payment for Environmental Services aiming to foster environmentally friendly behavior associated with the cultivation of rubber agroforestry. Under the individual scheme, participants received the incentive individually for each unit of endowment individually allocated for conservation. In the collective incentive scheme, every group member received the incentive once the total number of land units allocated to the conservation of rubber agroforestry in a group reached a minimum threshold level.

Further descriptions of the different data sources are provided in the methodology section of each essay.

\section{Dissertation outline}

The dissertation comprises two essays and is organized as follow. Chapter 2 presents the first essay. Chapter 2. Do beliefs and social capital matter when adopting modern irrigation technologies? The effect of social capital on attitudes, subjective norms, perceived control and intention and on actual behavior of adoption of pressurized irrigation systems is analyzed using structural equation modeling. Chapter 3 . Social capital and conservation under collective and individual incentive schemes: a framed field experiment in Indonesia presents the findings of the effectiveness of individual vs collective incentives for conservation behavior by cultivating rubber agroforestry. Chapter 4. Concluding remarks provides the overall conclusions and discusses implications and limitations of the research. 


\title{
Chapter 2. Planned behavior and social capital: Understanding farmers' behavior toward pressurized irrigation technologies?
}

\author{
Gracia Maria Lanza Castillo ${ }^{a, b}$, María Alejandra Engler Palma ${ }^{b, c}$, Meike Wollni a \\ a Department of Agricultural and Rural Development Economics, University of Göttingen, Göttingen, \\ b Departamento de Economía Agraria, Universidad de Talca, 2 Norte 685, Talca, Chile \\ ${ }^{c}$ Associate Researcher Núcleo Milenio CESIEP, Talca, Chile
}

\begin{abstract}
Water scarcity is becoming a major challenge worldwide. The agricultural sector, as a main user of freshwater, may significantly increase its water use efficiency by promoting water saving strategies. This paper proposes a socio-psychological model that builds upon the Theory of Planned Behavior and social capital variables to examine how psychological constructs and their interaction with the environment and farmers' _backgrounds influence the switch from traditional to pressurized irrigation. Considering temporal precedence, we measured farmers' _intention to adopt irrigation technologies, and one year later their actual behavior. We used a structural equation model and estimated marginal effects for direct and indirect relations. The results show that actual adoption is affected directly by intention, and the effect of subjective norms, perceived control, and attitudes on adoption are mediated through intention. Social pressure exerts a strong influence on farmers, particularly in comparison to their own attitudes. Social capital triggers the adoption of pressurized irrigation by increasing social pressure and strengthening farmers'_perceived self-confidence.
\end{abstract}

Keywords: social capital, theory of planned behavior, irrigation, and adoption.

Published in

Lanza Castillo, Gracia Maria, Alejandra Engler, and Meike Wollni. 2021. "Planned Behavior and Social Capital: Understanding Farmers' Behavior toward Pressurized Irrigation Technologies." Agricultural Water Management 243 (January): 106524. https://doi.org/10.1016/j.agwat.2020.106524.

The author's contribution is as follows: ME designed the survey. ME collected the data. GL analyzed and interpreted the data. GL wrote the paper. ME and MW commented to the final draft. 


\section{Introduction}

Water scarcity attributed to climate change and increasing population (IPCC, 2014; Fader, 2016) is becoming one of the most relevant challenges worldwide. Global water demand is projected to increase by $20 \%$ to $30 \%$ by 2050 (using as baseline, 2018), from which industrial and domestic use are expected to grow faster (Boretti and Rosa, 2018). Given that agriculture is the main user of freshwater, with approximately $70 \%$ of the total availability, and an expected increase in irrigation water demand of $16 \%$ by 2050 (baseline 2000, (Motoshita et al., 2018; Pastor et al., 2019; Jordán and Speelman, 2020), policies aimed at promoting water saving strategies in the agricultural sector may have a major positive impact on the sustainability of the resource (Nair, 2019). Scholars have pointed out that efficient irrigation technologies, irrigation scheduling, and smart agriculture at the farm level, as well as basin management strategies and diversification of water sources, are valuable approaches to cope with the current scenario (Rosegrant et al., 2000; Hess and Knox, 2013; Tran et al. 2016; Zhang et al. 2019; Galioto et al. 2020). Fader et al. (2016) concluded that efficient irrigation technologies such as drip and sprinklers can save up to $35 \%$ of water in the Mediterranean and similar results were found by Koech et al. (2018) in Australia. Aitken et al. (2016) in a study in Chile provides evidence that using irrigation technologies can reduce scarcity by $19 \%$. Moreover, Ahumada et al. (2017) concluded that limiting water by $20 \%$ does not affect yields in olive orchards in Chile. However, regardless of the favorable evidence, the adoption of efficient irrigation technologies is rather low. Worldwide, only $14 \%$ of the total of 275 million ha of irrigated land uses pressurized irrigation (Araujo, 2019). Hence a key question for policy makers is how to increase the use of technologies that can meet higher efficiency in water use. To date, the prevailing approach to understanding the drivers of farmers' decisions regarding the adoption of water efficient technologies and practices is economic rationality, whereby the individual is motivated by the objective of maximizing his/her utility, subject to a series of constraints related to farm size, low levels of education, and limited financial resources (Edwards-Jones, 2006; Jara-Rojas et al., 2012; Chen et al., 2014; Roco et al., 2014; Engler et al. 2016; Handschuch and Wollni, 2016). However, decisions are more complex than what purely economic rationality would indicate, and decisions also depend on cognitive and sociological variables (Yazdanpanah et al., 2014; Czap et al., 2016; Hunecke, 2017; Zeweld et al. 2017; Monteleone et al. 2019). Besides socio-economic constraints and drivers, individual behavior is based on the perceived value of the effectiveness, ease and/or difficulty, and advantages and/or disadvantages of the technology, all of which are subject to socialpsychological factors (Foster and Rosenzweig, 2010). Given this broader context to water-use 
decision-making, it is clear that we need to thoroughly elucidate the factors directing farmers' behavior adoption (Klöckner, 2013).

A widely used approach to explain individual behavior in the field of economic-psychology is the Theory of Planned Behavior (TPB) (Ajzen, 1985; Hansson et al., 2012; Yazdanpanah et al., 2015; De Leeuw et al., 2015; Monteleone, 2019). TPB proposes that the intention of a behavior acts as a mediator of attitude (individual beliefs with respect to the outcome of behavior), subjective norms (individual perception of social pressure), and perceived control (an individual's opinion about their ability to carry out a particular behavior) (Glanz et al., 2008; Fishbein and Ajzen, 2011). TPB has also been applied to agriculture (Borges et al., 2014; Yazdanpanah et al., 2014; Chin et al., 2016; Senger et al., 2017); however, few studies have applied the full model that includes the link between intention and actual behavior (Yazdanpanah et al., 2014; Meijer et al., 2015; Borremans et al., 2016; Niles et al., 2016). A downside of the aforementioned studies is that they estimate the relationship between intention and adoption at the same point in time, whereas the inference of a causal relation must have a temporal precedence (Kline, 2012; De Leeuw et al., 2015). Additionally, the agricultural literature has highlighted some shortcomings of TPB because it only focus on cognitive constructs and thus excludes the effect of the farmers' environment and their interaction with the community, which can be considered an asset and produces private benefits (Durlauf, 2002; Sidibé, 2005; Ramirez, 2013; Zeweld et al. , 2018).

This study aims to bridge these two gaps from the literature, (a) first by proposing a sociopsychological model that examines how psychological constructs and their interaction with the farmers' environment influence their intention to switch from traditional to pressurized irrigation, and (b) second by using a temporal scheme to link intention of adoption and actual behavior. There is a rich literature that uses social capital (networks, norms, and trust) to account for the relationship between the individual and the environment as a predictor of adoption behavior, concluding that the probability of adoption increases as the individual has more and deeper networks, higher trust in the surrounding community, and higher exposure to social norms (Esterhuyse, 2012; van Rijn et al., 2015; Wossen et al., 2015; Hunecke et al., 2017). This leaves an unexplored question: how does the social context in which the farmers are embedded influence the cognitive constructs of decision-making? We additionally explore the role of socio-economic constraints in the decision to adopt pressurized irrigation and the 
association between the intention measured in year $t_{0}$ and the actual behavior in $t_{1}{ }^{1}$.We test the socio-psychological model with vineyard farmers in the Maule and O'Higgins Regions of Chile, where adoption rates of pressurized irrigation are low despite the fact that pressurized irrigation has been proven to increase productivity and quality in vineyard and fruit species (Ahumada, et al. 2017; Acevedo -Opazo, 2010), and that the Chilean government implemented Decree law 18.450 to promote the construction and improvement of irrigation systems co-financing up to $80 \%$ of the total investment (Donoso, 2015; Hearne and Donoso, 2014a; CNR, 2020). Hence, understanding farmers' motivations and the relationships between social and psychological factors will provide insights into strategies that promote adoption and counteract those perceptions that delay and/or hinder adoption (De Leeuw et al., 2015).

\section{Theoretical framework and hypothesis}

We propose an integrated theoretical framework that considers social, psychological, and economic factors. As a basis for this framework, we use the Theory of Planned Behavior (TPB) to account for cognitive constructs that have been proven in the psychology literature to influence behavior (Conner and Armitage, 1998; Ajzen, 2002; De Leeuw et al., 2015), and extend this to include farmers' social capital characteristics (network, levels of trust, and membership) which have been identified to have an effect on psychological variables (attitudes, norms, perceived control) (Willock et al., 1999; Nuthall, 2001). There are other experiences accounting for extensions of the TPB; for example, Yazdanpanah et al. (2014) extended the TPB model with moral norms, self-identity, and perceived risk in order to analyze an unobservable variable measuring water conservation in Iran, concluding that intention was mostly explained by norms and that perceived control does not affect intention or behavior. Another study that proposes an integrated approach including TPB, Value-Beliefs-Norm theory, and Norm-Activation theory was performed by Klöckner (2013). In essence, he found that the TPB model alone cannot provide full insight into conservation behavior and that the relation between intention and behavior is dependent on the type of decision under analysis.

\footnotetext{
${ }^{1}$ Based on recommendations from the Ministry of Agriculture, one year is a reasonable timeframe to observe changes in adoption. Farmers do have access to financial and extension services (in different degrees).
} 
For the purpose of our study, we follow the TPB framework proposed by Ajzen (1985), which proposes that intention acts as a mediator of attitude, subjective norms, and perceived control in explaining actual behavior (see Error! Reference source not found.) ( Glanz et al., 2008; Fishbein and Ajzen, 2011; Manteleone, 2019). Specifically, attitude indicates the individual's belief with respect to the outcome of performing a behavior (behavioral beliefs) and the evaluation of those results (Glanz et al., 2008). Subjective norms are defined by how the individual weights the expectations of "important others" regarding a certain behavior corresponding to informal rules (Hansson et al., 2012; Bicchieri and Mercier, 2014). Ajzen (1991) included perceived behavioral control to explain aspects outside the individual's intention and behavior. Perceived control measures the individual's opinion about their ability to carry out a particular behavior and the term can be used interchangeably with selfconfidence or self-efficacy (Ajzen, 2002). In TPB, perceived control has an indirect effect through intention but could also have a direct effect on behavior if it were strong enough to be used as a measurement for actual control (Ajzen, 2002). From the above, we state the first hypothesis as:

$\mathrm{H} 1$. As farmers have a positive attitude towards the technology, feel social pressure to adopt, and perceive themselves to have the ability to act, they are more likely to adopt pressurized irrigation as their effects is mediated through intention to adoption.

Empirical studies have shown that these unobservable cognitive constructs are socially learned, changed, and expressed (Hogg and Terry, 2000); the scope of the TPB framework provides information with regards to the customary codes of behavior in a group or people or larger cultural context, but further information with regards to the complete dynamics of the social context or of the continuous state of change as a result of new experiences is required (Nuthall, 2001). Therefore, we include social capital variables to account for social context effects. The literature suggests that individual behavior is driven by particular experiences and by the environment (e.g., social comparison, social norms), with both being powerful factors in decision-making (Kollmuss and Agyeman, 2002; Ferraro and Price, 2013; Rode et al., 2015). To account for this, we include trust and networks (measured as membership and size of network). We recognize that although beliefs are relatively stable, they can be malleable as events unfold and new information about a person or issue becomes available (Fishbein and Ajzen, 2011). Specifically, beliefs about the outcome of a technology can change over time as new informal rules in a society are established (Slusher and Anderson, 1996). 


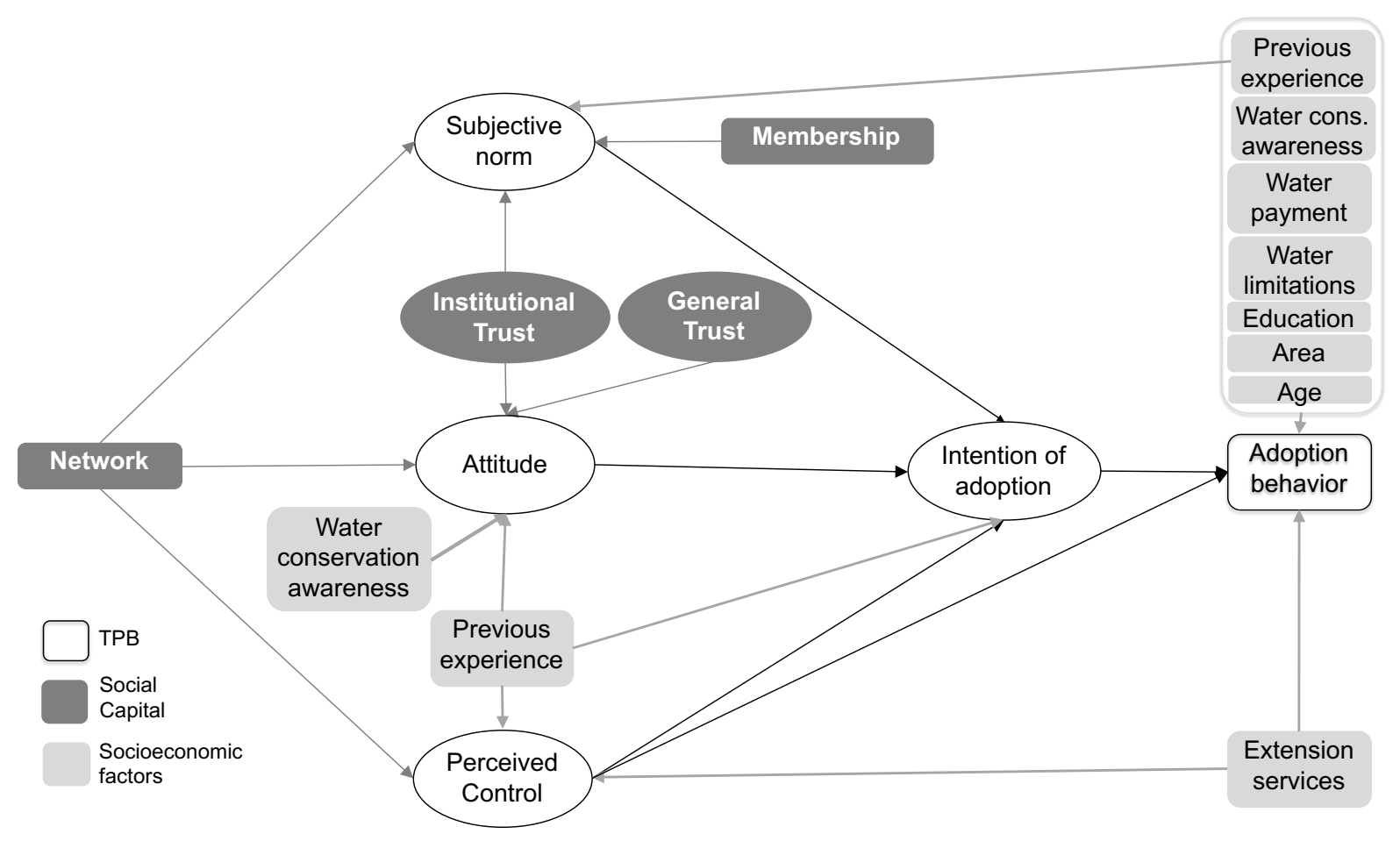

Figure 2. Theory of Planned Behavior (TPB) and social capital - a socio-psychological model Note: The diagram applies standard nomenclature, using ovals to identify latent variables and rectangles for directly measured variables.

Attitude changes can stem from different sources, but one important element related to technology adoption is trust, particularly because technologies are frequently promoted by the government or by non-governmental organizations (NGOs) from outside the community (Genius et al., 2014). Trust relates to the level of confidence that a farmer has towards an entity, and whether he can count on the trusted entity (Jones, 1996; Lyon, 2000; Sponarski et al., 2014;). In the case of technology adoption, it is important to differentiate between general and institutional trust: general trust refers to the level of confidence of the farmer that he can rely on his community in the event of need ( Lyon, 2000; Khalil, 2003; Carmeli and Spreitzer, 2009). Coleman (1988) highlights that trust facilitates productive activities by allowing groups to engage in information exchange and accomplish more when they have extensive trust (Coleman, 1988; Pannell et al., 2006; Wossen et al., 2015; Granja and Wollni, 2018). Institutional trust refers to trust in the government or NGOs, which will drive the subjective reliability of the source of information about the promoted technologies (i.e., how much farmers trust the source (Lyon, 2000)), thus affecting farmers' attitudes. In the context of governments promoting the transition from traditional to pressurized irrigation systems, it is therefore relevant to explore whether the level of trust in such institutions has an effect on attitudes. At 18 
the same time, institutional trust creates commitment from the farmer to behave according to the community's informal norms, thus inducing the formation of social norms (Coleman, 1988; Seddon and Levin, 2013). Summarizing the preceding review, we can state the following hypothesis:

H2. The higher the general and institutional trust, the more favorable will be the farmer's perception of the outcomes (attitude); higher institutional trust will further be associated with higher perceived pressure to behave according to the social norm.

A farmer's social environment is created by a social network that functions as a platform for interaction and communication with a circle of friends and peers, members of a local organization, and other important connections. These constant interactions affect farmers' beliefs, decisions, and behaviors (Jacques et al., 2018). Social networks allow individuals to connect, exchange ideas and experiences, look for help when in need or in doubt, and access new information, knowledge, and sources of credit ( Pelling and High, 2005; Esterhuyse, 2012; van Rijn et al., 2015). Farmers learn from each other and change their beliefs by learning from what others have adopted. Based on the above, we hypothesize the following:

H3. Farmers with a larger network using pressurized irrigation will feel more pressure to change from traditional to pressurized irrigation themselves but will also feel more confident to do so and will generally tend to have a more positive attitude towards pressurized irrigation.

H4. Members of a local water organization perceive more social pressure to adopt pressurized irrigation.

Nuthall (2001) indicated that previous experience influences decision making because lessons are processed instantaneously. Most farmers learn not only by testing a technology on their farms but also by exchanging experiences with close friends. Therefore, we include farmers' backgrounds to account for variables such as previous experience with pressurized irrigation technologies, environmental awareness, education, and age. Weber et al. (2004) highlighted that the decision process starts with some form of problem recognition; therefore, we analyze whether the perception of water limitations has a direct influence on the farmer's adoption of pressurized irrigation. Finally, we control for key variables that may play a role when farmers adopt irrigation, such as access to extension services, land area, and the fee paid to the water community for water use (Ervin and Ervin, 1982; Borges et al., 2014; Rubas, 2004; Prokopy 
et al., 2008). Although additional relationships could be analyzed, we focus on the above elements to maintain the parsimony of the model. Figure 1 depicts the relationships and hypotheses we are testing.

\section{Materials and methods}

\subsection{Study area}

In this study, we focus on vineyard agricultural systems, which produce some of the top export products in Chile. The study was carried out in the Maule and O'Higgins regions. Both are located in the central part of Chile, characterized by a Mediterranean climate that is especially suited for the production of vineyards and fruits. In 2017 , these regions contributed $34.8 \%$ of Chile's agricultural gross domestic product (GDP) and $32 \%$ of the exports from agriculture; moreover, the Maule and O'Higgins regions contribute a combined $42 \%$ of total wine exports (29\% and $13 \%$, respectively) (ODEPA, 2017). According to Easter and Huang (2014), during water shortages the Chilean water market promotes allocation to priority sectors; however,

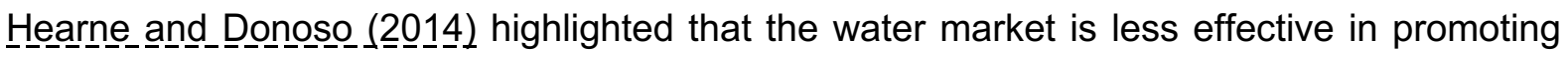
efficient water management, particularly in the agricultural sector. Despite the exhibited mega droughts since 2010 in central Chile (Garreaud et al., 2020), adoption of pressurized irrigation is still low and waster is perceived as abundant. According to McPhee et al. (2012) efficiency levels of irrigation systems in central Chile varies from $35-45 \%$, while in northern Chile,

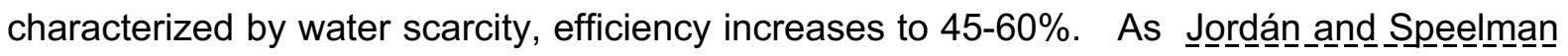
(2020ㄴ) highlighted, farmers are not incentivized to adopt pressurized irrigation due to the perceived relative abundance of water. Nonetheless, Lozanono_Parra et__al._(2020) forecast a reduction of $936 \mathrm{~mm} \mathrm{y}^{-1}$ in precipitation by 2050 in Chile, highlighting that with the increased in water demand by the population and agriculture to produce export products, competition among economic sectors is exacerbated. Therefore, pressurized irrigation technologies (e.g., drip irrigation) are becoming more relevant to the Chilean economy.

\subsection{Data collection}

The study applied a cross-sectional survey focused on collecting data about attitudes, perceived control, subjective norms, intentions, and the farmers' environment and backgrounds. The questionnaire was developed based on a literature review and was subsequently validated in a focus group that included experts from academia, farmers, public 
sector officers $\left(\mathrm{CNR}^{2}\right.$ and $\left.\mathrm{INDAP}^{3}\right)$, and extension services agents. In designing the questionnaire, a five-point Likert scale was used for all TPB variables (except for adoption behavior that is measured as a binary variable). The descriptors were strongly disagree, disagree, neither agree nor disagree, agree, and strongly agree.

The targeted population was small- and medium-scale vineyard farmers from 21 municipalities ${ }^{4}$ from three valleys (Cachapoal/Colchagua, Curico and Maule) of the O'Higgins and Maule regions, from which 324 farmers were selected. Producers were selected randomly in situ with a protocol of being at least $1 \mathrm{~km}$ apart from each other. The number of producers correspond to a stratified sample based the wine growing cadastral 2012 of the Agriculture and Livestock Service. The data were gathered in face-to-face interviews that were conducted between November 2014 and February 2015. Each farmer was informed that they were free to refuse to participate, and no payment was made to the farmers. Those who declined to participate were replaced by alternate respondents.

A telephone follow-up survey was conducted 12 months after the cross-sectional survey. We contacted all participants from the initial survey with a response rate of $91 \%$ (295 of the 324 participants). The brief (approx. 10-minute) telephone follow-up focused on asking the farmers if they had adopted or extended pressurized irrigation technology. This follow-up call verified short-term actual behavior with regards to adoption of pressurized irrigation technologies, and it facilitated a comparison with intentions declared the year before, thus assuring the condition of time precedence. Hence, TPB and social capital variables and socio-economic characteristics were gathered for year $t_{0}$ and actual adoption behavior for year $t_{1}$.

\footnotetext{
${ }^{2}$ National Irrigation Commission

${ }^{3}$ National Agricultural Development Institution

${ }^{4}$ The municipalities were, in order of number of surveyed producers: San Javier, Sagrada Familia, Curicó, Rancagua, Villa Alegre, Santa Cruz, Talca, Palmilla, San Clemente, Peralillo, Rio Claro, Requinoa, Chimarongo, Maule, San Vicente, and Peumo.
} 


\section{Empirical Data}

\subsection{Model specification}

We use structural equation modeling (SEM) to test the hypotheses regarding the relationship among cognitive, social, and socio-economic variables simultaneously including measurement errors (Yazdanpanah et al., 2014). SEM is a multivariate estimator generating coefficients that allow us to estimate the magnitude and statistical significance of the structural relation between the latent and observed variables of the theoretical model. Following Figure 1 , the empirical model is expressed in the following equations:

$$
\begin{aligned}
& A T T=\beta I T+\beta G T+\beta N e t w+\beta W C+\beta P E+\zeta_{1} \\
& S N=\beta I T+\beta N e t w+\beta M e m+\zeta_{2} \\
& P C=\beta N e t w+\beta E x t e n s+\beta P E+\zeta_{3} \\
& I N T=\beta A T T+\beta S N+\beta P C+\beta P E+\zeta_{4}
\end{aligned}
$$

And, adoption behavior

$$
\begin{aligned}
& A D O P=\beta I N T+\beta P C+\beta \text { Area }+\beta E x \text { tens }+\beta A g e+\beta W C+\beta E d u+ \\
& \beta W P+\beta W L+\beta P E+\zeta_{5}
\end{aligned}
$$

where $\zeta$ is the error vector, which represents the errors-in-equations.

The structural equations consider the latent variables of attitude (ATT), perceived control $(P C)$, intention (INT), and institutional trust (IT); and the observed variables of subjective norms $(S N)$, networks (Netw), membership (Mem) and general trust (GT) as for TPB and social capital variables. In the adoption behavior equation, we include variables such as water fee $(W F)$, water limitations $(W L)$, water conservation awareness $(W C)$, previous experience with pressurized irrigation $(P E)$, and control variables to complete the model relationships. The variable description is detailed in section 4.2.

The Shapiro-Wilk test showed that the variables are not normally distributed; therefore, we use the robust unweighted least squares (ULSMV) estimation procedure. The estimates of structural coefficients under ULSMV surpass maximum likelihood (ML) and robust maximum likelihood (MLR) in almost all asymmetric conditions, hence providing more robust standard errors under conditions of non-normality and when modeling categorical or ordered data ( $\mathrm{Li}$, 2014). Additionally, to infer a causal relation between two variables, several statistical 
conditions must be met, as specified by Kline (2012): 1) intention and adoption should be measured at two different points in time; 2) covariation among the variables should be observed (see correlation matrix in Table A1); and 3) the statistical association should hold when controlling for other covariates that may have an effect on the variable of interest, in this case adoption (existence of isolation).

To check the robustness of the model, we estimated three models using Equations 1 to 5, but with the following differences: Model 1 was estimated with the total sample (324 observations) and without control variables (WC, PE, WL, WP, Extens, Area, Age, and EDU); Model 2 tests full isolation by estimating the empirical model with the total sample and control variables; and Model 3 tests systematic differences among farmers with and without previous experience with pressurized irrigation technology by restricting the sample to farmer that at $t_{0}$ did not have pressurized irrigation, resulting in a sample of 198 observations.

Model fit is assessed using the comparative fit index (CFI), the Tucker-Lewis Index (TLI), and the root mean squared error of approximation (RMSEA). Conventional rules establish that a model is satisfactory if the CFI and TLI indices are higher than 0.9 , and a model is considered excellent if the values are higher than 0.95 for both indexes. For RMSEA, values below 0.08 are acceptable and below 0.06 are considered excellent (Hu and Bentler, 1999; Kline, 2015; Li, 2014). The model was estimated with MPlus 7.

\subsection{Variable description}

\subsubsection{Cognitive constructs (latent variables)}

For the cognitive constructs of attitude (ATT), perceived control (PC), intention (INT), and institutional trust (IT) we use a series of statements rated on a five-point scale from strongly disagree to strongly agree, following the guidelines and adjusted statements proposed by Ajzen (1991), to generate the factor scores that are used in the regressions. The literature uses Cronbach's alpha to measure internal consistency and the Kaiser-Meyer-Olkin (KMO) test to measure sampling adequacy; these indicators are not reported when estimating SEM in MPlus, hence we performed a factor analysis to validate the constructs. We estimate the Cronbach's alpha and the KMO, observing results higher than 0.8 for ATT, PC and INT, implying high internal consistency and adequacy. IT shows satisfactory results with a KMO of 0.73 and a Cronbach's alpha of 0.83 . Table A2 in the Appendix show results of factor analysis. Table 1 presents the average value of the constructs. 


\subsubsection{Observed variables}

Observable variables were measured through direct questions in the survey. For instance, to measure SN we follow Mobley et al. (2010) by asking: (1) "the water community to which I belong expects me to adopt pressurized irrigation technology" and (2) "other farmers look favorably upon me or would look favorably upon me if I adopted modern irrigation". Both statements use a series of statements rated on a five-point scale from strongly disagree to strongly agree and were averaged to deliver the variable $S N$.

Networks were measured with two variables: (1) Netw: number of the farmer's acquaintances who have adopted pressurized irrigation technologies; and (2) Mem: participation in water organizations is a binary variable equaling 1 when the farmer was part of a water organization and 0 otherwise. Following Grootaert (2003), GT was measured based on the statement "I can trust the people around me without being too cautious", using a five-point scale from strongly disagree to strongly agree.

Background information on the farmers includes land tenure, area of their property, years of education, access to extension services, water fee (measured in Chilean pesos paid annually by the farmer ${ }^{5}$ ), previous experience $(P E)$ with pressurized irrigation (take the value of 1 if the farmer has had any previous experience implementing pressurized irrigation system in their farm, or 0 otherwise), water limitations $(W L)$ ( = 1 if the farmer has reported limitations on irrigation due to water shortages, 0 otherwise), and his level of water conservation awareness (WC). Water conservation awareness is measured using the statement "I would adopt modern irrigation technology because it helps to conserve water". Descriptive statistics of these variables are provided in Table 1.

\footnotetext{
${ }^{5}$ The fee is a flat rate that is not based on the actual water quantity being used.
} 


\section{Results}

\subsection{Descriptive statistics}

\subsubsection{Characteristics of the sample}

Basic sociodemographic characteristics show that the average age of the farmers is $\mathbf{5 2 . 7 6}$ years, $91 \%$ are male, and on average, they have 11.57 years of schooling. The baseline data show that 126 farmers (39\%) have previous experience with pressurized irrigation, either because they have partially adopted it on their land or had it at some point in the past, and 198 farmers $(61 \%)$ have no experience. We observe that farmers who have experience with pressurized irrigation are significantly younger and have: more years of schooling (13.12 years), less farming experience, higher area of land in tenure, additional sources of income (other than agriculture), and a higher perception of water limitations compared to those that have no experience with pressurized irrigation systems (Table 1).

Extension services are provided free of charge by agricultural associations or by the Institute for Agricultural Development (INDAP) of the Agricultural Ministry, and these services have been used by $38 \%$ of the farmers in the sample. Regarding land tenure, most of the land is owned. According to the organization of water distribution system, farmers must pay their water communities a fee for the water rights they own; in our sample, $80 \%$ of the farmers pay an annual fee for their water right, independent of consumption. The yearly payment was 20,176 Chilean pesos on the average, which is equivalent to US\$32.18.

Table 1. Descriptive Statistics baseline data (Standard deviation in parenthesis)

\begin{tabular}{lcccc}
\hline Variables & $\begin{array}{c}\text { Total sample } \\
(\mathrm{n}=324)\end{array}$ & $\begin{array}{c}\text { Without previous } \\
\text { experience } \\
(\mathrm{n}=198)\end{array}$ & $\begin{array}{c}\text { With previous } \\
\text { experience } \\
(\mathrm{n}=126)\end{array}$ & $\mathrm{z}^{1}$ \\
Mean & Mean & & \\
Farmer background & 52.76 & 56.52 & 46.84 & $6.09^{\star * *}$ \\
\hline Age (years) & $(13.87)$ & $(13.48)$ & $(12.37)$ & \\
Education (years) & 11.57 & 10.58 & 13.12 & $-5.48^{* * *}$ \\
& $(4.09)$ & $(4.14)$ & $(3.49)$ & \\
Farming experience (years) & 29.17 & 33.43 & 22.46 & $6.06^{* * *}$ \\
& $(16.24)$ & $(16.08)$ & $(14.14)$ & \\
\hline
\end{tabular}




\begin{tabular}{|c|c|c|c|c|}
\hline Variables & $\begin{array}{l}\text { Total sample } \\
\qquad(n=324)\end{array}$ & $\begin{array}{c}\text { Without previous } \\
\text { experience } \\
(n=198)\end{array}$ & $\begin{array}{l}\text { With previous } \\
\text { experience } \\
\quad(n=126)\end{array}$ & $z^{1}$ \\
\hline & Mean & Mean & Mean & \\
\hline $\begin{array}{l}\text { Other sources of income } \\
\text { besides agriculture ( }=1 \text { if yes) }\end{array}$ & $\begin{array}{c}0.06 \\
(0.24)\end{array}$ & $\begin{array}{c}0.03 \\
(0.17)\end{array}$ & $\begin{array}{c}0.11 \\
(0.31)\end{array}$ & $4.007^{* * \star}$ \\
\hline Area (has) & $\begin{array}{c}72.87 \\
(143.5)\end{array}$ & $\begin{array}{c}30.82 \\
(49.71)\end{array}$ & $\begin{array}{c}138.96 \\
(205.27)\end{array}$ & $-9.11^{* * *}$ \\
\hline $\begin{array}{l}\text { Access to extension services } \\
\text { ( }=1 \text { if farmer has access to } \\
\text { adviser) (Extens) }\end{array}$ & $\begin{array}{c}0.38 \\
(0.48)\end{array}$ & $\begin{array}{c}0.26 \\
(0.44)\end{array}$ & $\begin{array}{c}0.56 \\
(0.49)\end{array}$ & $-5.33^{* * *}$ \\
\hline $\begin{array}{l}\text { Irrigation limited due to water } \\
\text { shortages ( } 1=\text { if yes) (WL) }\end{array}$ & $\begin{array}{c}0.32 \\
(0.46)\end{array}$ & $\begin{array}{c}0.27 \\
(0.44)\end{array}$ & $\begin{array}{c}0.39 \\
(0.49)\end{array}$ & $-2.22^{* *}$ \\
\hline Water fee ( $=1$ if yes) & $\begin{array}{c}0.80 \\
(0.39)\end{array}$ & $\begin{array}{c}0.77 \\
(0.42)\end{array}$ & $\begin{array}{c}0.84 \\
(0.35)\end{array}$ & $-1.68^{* *}$ \\
\hline $\begin{array}{l}\text { Water fee (Chilean } \\
\text { pesos/action(ha) (WF) }\end{array}$ & $\begin{array}{c}20176 \\
(26715)\end{array}$ & $\begin{array}{c}19348 \\
(24022)\end{array}$ & $\begin{array}{c}22120 \\
(32259)\end{array}$ & 0.034 \\
\hline Farmer social environment & & & & \\
\hline General trust (GT) & $\begin{array}{c}3.58 \\
(1.15)\end{array}$ & $\begin{array}{c}3.65 \\
(1.13)\end{array}$ & $\begin{array}{c}3.48 \\
(1.17)\end{array}$ & 1.23 \\
\hline Institutional trust (IT) & $\begin{array}{c}3.28 \\
(1.11)\end{array}$ & $\begin{array}{c}3.30 \\
(1.13)\end{array}$ & $\begin{array}{c}3.25 \\
(1.09)\end{array}$ & 0.43 \\
\hline Network (Netw) & $\begin{array}{c}6.04 \\
(9.35)\end{array}$ & $\begin{array}{c}4.68 \\
(7.99)\end{array}$ & $\begin{array}{c}8.19 \\
(10.84)\end{array}$ & $-6.01^{* * *}$ \\
\hline $\begin{array}{l}\text { Membership in a local } \\
\text { organization (Mem) }\end{array}$ & $\begin{array}{c}0.23 \\
(0.42)\end{array}$ & $\begin{array}{c}0.22 \\
(0.41)\end{array}$ & $\begin{array}{c}0.25 \\
(0.43)\end{array}$ & -0.635 \\
\hline Attitude (ATT) & $\begin{array}{c}4.97 \\
(0.73)\end{array}$ & $\begin{array}{c}4.32 \\
(0.70)\end{array}$ & $\begin{array}{c}4.64 \\
(0.49)\end{array}$ & $-3.572^{* * *}$ \\
\hline Subjective norm (SN) & $\begin{array}{c}3.39 \\
(1.01)\end{array}$ & $\begin{array}{c}3.25 \\
(1.00)\end{array}$ & $\begin{array}{c}3.60 \\
(0.984)\end{array}$ & $-3.021^{* *}$ \\
\hline Perceived control (PC) & $\begin{array}{c}3.57 \\
(1.48)\end{array}$ & $\begin{array}{c}2.98 \\
(1.48)\end{array}$ & $\begin{array}{c}4.57 \\
(0.80)\end{array}$ & $-9.692^{* * *}$ \\
\hline Intention (INT) & $\begin{array}{c}3.18 \\
(1.34)\end{array}$ & $\begin{array}{c}2.90 \\
(1.28)\end{array}$ & $\begin{array}{c}3.82 \\
(1.24)\end{array}$ & $-6.096^{* * *}$ \\
\hline
\end{tabular}

${ }^{1} \mathrm{z}$-value for the Wilcoxon rank-sum test $* \mathrm{p}<0.1,{ }^{* *} \mathrm{p}<0.05, * * * \mathrm{p}<0.01$

On average, farmers have moderate levels of general and institutional trust, with mean values of 3.58 and 3.28 (on a scale of 1 to 5 ), respectively. The average number of known 
acquaintances that use pressurized technologies is 6 , and there is a significant difference between farmers who have previous experience with pressurized irrigation technology as they have almost twice the number of acquaintances compared to farmers who have no experience with irrigation technology. Participation in local organizations is relatively low: only $23 \%$ of the sample participates in a water organization.

When analyzing the cognitive constructs of TPB, we observe moderate intentions to adopt pressurized irrigation technologies, with an average value of 3.18 (on a scale of 1 to 5), a positive attitude (with a score of 4.97), moderate subjective norm (3.39) and moderate perceived control (3.57). Comparing the values of farmers with and without previous experience with pressurized irrigation, there are significant differences in all these constructs, with those who have previous experience reporting higher scores on all aspects. The comparison between these two groups provides support for the hypotheses presented in section 2. The differences found here between the two groups regarding attitudes, subjective norms, perceived control, intention, and social capital variables are consistent with the literature and highlight the importance of considering farmers' context and social environment when analyzing intentions and actual adoption behavior.

\subsubsection{Relation between intention and actual behavior}

Actual behavior was measured 12 months after the application of the cross-sectional survey. Adopters are defined as those farmers who had either adopted or extended pressurized irrigation during the previous twelve months. For comparison and descriptive purposes, we recoded the variable intention (originally measured on a Likert scale from 1 to 5 ) into a dummy variable, where scores of $\geq 3$ take the value of 1 aggregating the responses of those farmers with declared intention to adopt pressurized irrigation in the following year, and scores $<3$ take the value $0^{6}$. Figure shows that $58 \%$ of the farmers stated an intention to adopt, and $17 \%$ adopted, pressurized irrigation technology. When comparing farmers with and without

\footnotetext{
${ }^{6}$ The recode of the intention variables was used only for comparison in the descriptive section. In the econometric analysis we used the five statements of intention as originally measured on a Likert scale from 1 to 5 , therefore in the econometric analysis the factor scores were used in the regression.
} 
previous experience, we find significant differences with respect to both intentions and actual behavior.

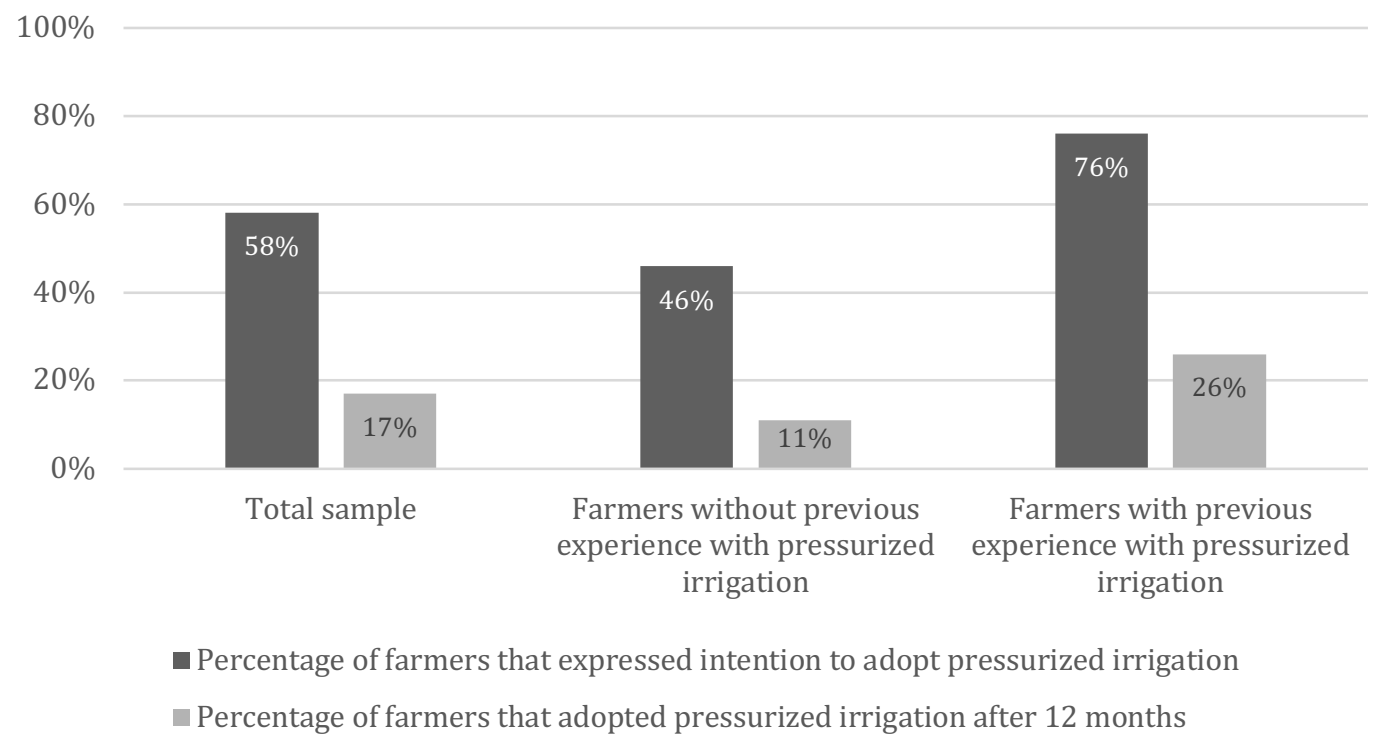

Figure 2. Comparison of intention to adopt, and actual adoption of, pressurized irrigation.

Among farmers with previous experience, $76 \%$ have the intention to adopt or expand the use of pressurized irrigation technology, while only $46 \%$ of the farmers without previous experience have such intention. Regarding actual behavior, $26 \%$ of the farmers with experience adopted the technology, compared to only $11 \%$ of the farmers without experience. These results support the hypothesis that knowledge can shape the attitudes and intentions of farmers.

\subsection{SEM results}

As explained in section 4, we estimate three different model specifications to check the robustness of the multiple relations proposed in the theoretical framework. Model 1 estimates the relationships among the cognitive constructs of TPB and social capital variables without control variables. Model 2 estimates the relationships as in model 1, but additionally incorporates control variables to verify the assumption of isolation. Model 3 constrains the sample to those farmers who have not had any previous experience with pressurized irrigation technology. All three models present a satisfactory fit based on the criteria formulated by $\mathrm{Hu}$ and Bentler (1999) (Table 2), which compare the residual differences between the fitted and the sample covariance matrices. 
With respect to the classical TPB variables, Model 1 shows that attitudes, subjective norms, and perceived control have positive and significant effects on intention (Eq. 4). Subjective norms exhibit the highest estimated coefficient $(\beta=0.434, p<0.001)$, followed by perceived control $(\beta=0.280, p<0.001)$, and attitudes $(\beta=0.138, p<0.05)$, indicating that social pressure exerts a strong influence on farmers, particularly in comparison to their own attitudes. These results align with previous studies that have emphasized the influence of perceived social pressure on adoption (Renfroe et al., 1990; Burton, 2014). All three variables together explain $43.5 \%$ of the variance in intention. Furthermore, Model 1 reveals that intention ${ }^{7}$ has a significant and positive effect on adoption (Eq. 5), and thus, confirms that intention to engage in an action is the proximal antecedent of voluntary action (Ajzen, 2002; De Leeuw et al., 2015). Based on these results, we can corroborate hypothesis $\mathrm{H} 1$ that farmers' attitudes, subjective norms, and perceived control have a positive effect on intention and adoption of pressurized irrigation systems.

Regarding the social capital variables, we observe mixed results. Model 1 shows that institutional trust is positively related to attitudes and subjective norms, while general trust is positively related to attitudes, thus supporting $\mathrm{H} 2$. These findings imply that higher levels of trust are associated with positive perceptions of the action outcomes (attitudes). Institutional trust can be seen as a cooperation agreement between the farmer and the institutions providing extension services, and therefore farmers feel committed to act according to the social norms embodied by these institutions (Khalil, 2003). The size of the network (Netw) is statistically related to perceived control, indicating that farmers will feel more confident about their ability to implement the technology when they are embedded in a large network of other adopters, thus partially supporting H3. Contrary to our expectations, Netw does not have significant effects on attitudes and subjective norms. Finally, membership in water organizations has a positive effect on subjective norms, which corroborates $\mathrm{H} 4$.

\footnotetext{
${ }^{7}$ As explained in section 4.2.1, intention is a latent variable estimated in SEM with all parameters simultaneously. It considers the statements indicated in appendix A2. Thus, intention is a factor score with the estimates for the true latent variable scores (Devlieger and Rosseel, 2017).
} 
Chapter 2. Planned behavior and social capital: Understanding farmers' behavior toward pressurized irrigation technologies?

Table 2. Standardized regression coefficients (Standard errors in parenthesis)

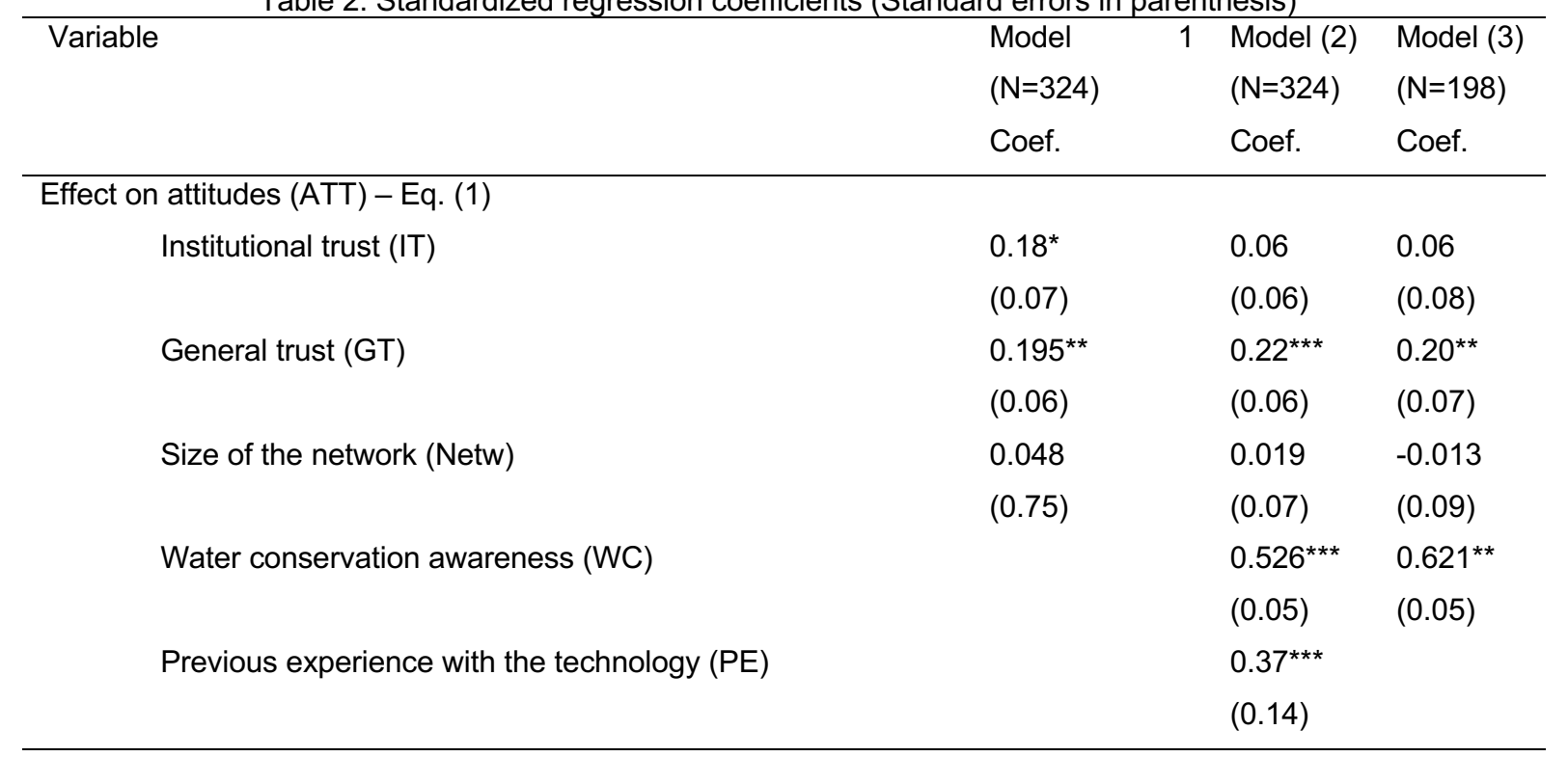

Effect on subjective norms (SN) - Eq. (2)

$\begin{array}{llll}\text { Institutional trust (IT) } & 0.33^{* * *} & 0.22^{* * *} & 0.31^{* *} \\ \text { Size of the network (Netw) } & (0.06) & (0.07) & (0.1) \\ \text { Membership (Mem) } & 0.12 & 0.13 & 0.07 \\ & (0.1) & (0.10) & (0.12) \\ & 0.19^{* *} & 0.21^{* *} & 0.22^{*} \\ & (0.09) & (0.10) & (0.12)\end{array}$

Effect on perceived control (PC) - Eq. (3)

$\begin{array}{llll}\text { Size of the network (Netw) } & 0.32^{* * *} & 0.21^{* * *} & 0.31^{* * *} \\ \text { Access to extension services (Extens) } & (0.07) & (0.06) & (0.10) \\ & & 0.15^{\star *} & 0.15^{\star *} \\ \text { Previous experience with the technology (PE) } & & (0.05) & (0.07)\end{array}$

Effect on intention (INT) Eq. (4)

$\begin{array}{llll}\text { Attitude (ATT) } & 0.14^{*} & 0.19^{* *} & 0.22^{* *} \\ & (0.07) & (0.07) & (0.09) \\ \text { Subjective norms (SN) } & & & \\ & & & \\ \text { Perceived control (PC) } & (0.06) & (0.05) & (0.06) \\ & 0.23^{* * *} & 0.19^{* *} & 0.18^{* *} \\ \text { Previous experience with the technology (PE) } & (0.06) & (0.07) & (0.07) \\ & & 0.17^{* *} & \end{array}$


Chapter 2. Planned behavior and social capital: Understanding farmers' behavior toward pressurized irrigation technologies?

\begin{tabular}{lllll}
\hline Variable & Model & 1 & Model (2) & Model (3) \\
& $(\mathrm{N}=324)$ & $(\mathrm{N}=324)$ & $(\mathrm{N}=198)$ \\
& Coef. & Coef. & Coef. \\
\hline
\end{tabular}

Effect on adoption of pressurized irrigation (ADOP) - Eq. (5)

$\begin{array}{llll}\text { Intention (INT) } & 0.31^{* * *} & 0.21^{* *} & 0.40^{* *} \\ & (0.10) & (0.10) & (0.13) \\ \text { Perceived control (PC) } & & & \\ & 0.01 & -0.07 & -0.072 \\ \text { Physical capital (area in hectares) (Area) } & (0.11) & (0.12) & (0.13) \\ & & 0.12^{*} & 0.18 \\ \text { Access to extension services (Extens) } & (0.07) & (0.12) \\ \text { Age } & 0.04 & -0.118 \\ & & (0.10) & (0.14) \\ \text { Water conservation awareness (WC) } & -0.10 & 0.05 \\ & & (0.10) & (0.14) \\ \text { Education (Edu) } & 0.10 & 0.05 \\ & & (0.09) & (0.13) \\ \text { Water Fee (WF) } & & 0.13 & 0.32^{*} \\ & & (0.11) & (0.17) \\ \text { Water limitations for irrigation (WL) } & 0.04 & -0.22 \\ \text { Previous experience with the technology (PE) } & (0.09) & (0.21) \\ & & 0.15^{*} & 0.67^{*} \\ & & (0.09) & (0.27) \\ & & 0.09 & \end{array}$

Goodness of fit indicators

Chi-Square / Degree of Freedom relation

$\mathrm{CFI}$

$\begin{array}{lll}1.65 & 1.06 & 1.05 \\ 0.94 & 0.96 & 0.94 \\ 0.93 & 0.95 & 0.93 \\ 0.045 & 0.014 & 0.017 \\ 0.037-0.053 & 0.000 & -0.000- \\ & 0.025 & 0.032\end{array}$

Note: The model estimates linear regression coefficients for continuous variables such as attitudes, subjective norms, perceived control and intention. For limited dependent variables that model estimates Probit coefficients. 
Model 2, which includes additional control variables, generates results that are consistent with Model 1 (i.e., most of the statistical associations persist). Overall, Model 2 explains $21.3 \%$ of the variance in actual adoption behavior (Eq. 5). Previous experience (PE) with the technology contributes to a positive attitude, to higher perceived control and intentions to adopt. In the adoption equation (Eq. 5), only physical capital and water limitations for irrigation have positive and significant effects. Model 3 shows consistency with the findings of Model 2 for the cognitive constructs.

Further, we estimated the marginal effects of the explanatory variables on the dependent variable adoption $(A D O P)$, including direct, indirect, and total effects. For this purpose, we use model 2 because it controls for additional covariates and presents the best goodness of fit. Table 3 provides the direct, indirect and total marginal effects ${ }^{8}$ of each variable on the probability of adoption $(A D O P)$.

Table 3. Direct, indirect and total effects on adoption

\begin{tabular}{|c|c|c|c|c|c|c|}
\hline \multirow{2}{*}{ Variables } & \multicolumn{3}{|c|}{ Standardized Coefficients } & \multicolumn{3}{|c|}{ Marginal Effect (prob) } \\
\hline & Direct & Indirect & Total & Direct & Indirect & Total \\
\hline \multicolumn{7}{|l|}{ Cognitive constructs } \\
\hline Intention (INT) & $0.21^{* *}$ & & $0.21^{* *}$ & $0.04^{* *}$ & & $0.04^{* *}$ \\
\hline Attitude (ATT) & & $0.04^{*}$ & $0.04^{*}$ & & $0.016^{*}$ & $0.01^{*}$ \\
\hline Perceived control (PC) & -0.07 & $0.04^{*}$ & -0.03 & 0.01 & $0.01^{*}$ & 0.01 \\
\hline Subjective norms (SN) & & $0.07^{* *}$ & $0.07^{\star *}$ & & $0.02^{* *}$ & $0.02^{\star \star}$ \\
\hline \multicolumn{7}{|c|}{ Farmers social environment } \\
\hline Institutional trust (IT) & - & $0.018^{*}$ & $0.018^{*}$ & & $0.01^{*}$ & $0.01^{*}$ \\
\hline General trust (GT) & - & 0.009 & 0.009 & & & 0.01 \\
\hline Size of the network (Netw) & 0.004 & 0.015 & 0.019 & 0.014 & 0.01 & 0.01 \\
\hline Membership (Mem) & - & $0.041^{*}$ & $0.041^{*}$ & & $0.01^{*}$ & $0.01^{*}$ \\
\hline
\end{tabular}

Farmers' background

\begin{tabular}{lllll} 
Area & $0.12^{*}$ & $0.12^{*}$ & $0.02^{*}$ & $0.02^{*}$ \\
Age & -0.10 & -0.10 & 0.00 & 0.00 \\
\hline
\end{tabular}

\footnotetext{
${ }^{8}$ We estimate the Probit Regression Probabilities based on Muthén and Muthén (2009).
} 
Chapter 2. Planned behavior and social capital: Understanding farmers' behavior toward pressurized irrigation technologies?

\begin{tabular}{lcccccc}
\hline \multirow{2}{*}{ Variables } & \multicolumn{3}{c}{ Standardized Coefficients } & \multicolumn{3}{c}{ Marginal Effect (prob) } \\
& Direct & Indirect & Total & \multicolumn{2}{c}{ Direct } & Indirect Total \\
\hline Education (Edu) & 0.13 & & 0.13 & 0.04 & 0.034 \\
Water fee (WF) & -0.04 & & -0.04 & 0.01 & 0.01 \\
Water limitations for irrigation (WL) & $0.15^{*}$ & & $0.15^{*}$ & $0.02^{*}$ & $0.02^{*}$ \\
Water conservation awareness (WC) & 0.10 & $0.02^{*}$ & 0.12 & 0.04 & $0.02^{*}$ & 0.06 \\
Extension services (Extens) & 0.04 & -0.00 & 0.03 & 0.01 & 0.01 & 0.01 \\
Previous experience with the technology & 0.09 & 0.03 & 0.12 & 0.02 & 0.01 & 0.02 \\
(PE) & & & & & & \\
\hline
\end{tabular}

The results show that attitudes (ATT), perceived control (PC), and subjective norms (SN) have significant indirect effects on adoption (ADOP), and that they are effectively mediated through intention. Membership in water organizations $(\mathrm{Mem})$ increases the probability of adoption indirectly, because its effects are mediated through subjective norms. This finding can be explained by the well-established institutions in the Chilean Water Code that define water community organizations as key to water management. This is also reflected in the institutional trust that farmers have in these organizations. Higher institutional trust levels indirectly increase the likelihood of adoption through their positive effects on attitudes (ATT).

With regard to control variables, having water limitations $(W L)$ for irrigation shows a direct effect on the adoption of irrigation technologies. As expected, water fee (WF) shows no effect on adoption $(A D O P)$, because the payment is not dependent on water consumption. To provide an incentive for more efficient water use, charges must be a direct function of consumption ( Southgate and Figueroa, 2006; De Fraiture and Perry, 2007). Extension services (Extens) show a significant effect on perceived control $(P C)$, but not on adoption (ADOP). Physical capital (Area), measured as farm size in hectares, positively and significantly influences adoption, meaning that larger farmers are more likely to adopt due to scale economies and larger capacity to bear risk (Diederen et al., 2003; Jara-Rojas et al., 2012). Finally, we observe that water conservation awareness (WC) indirectly and positively impacts the likelihood of adoption mediated through its positive effect on attitudes and intentions.

\section{Discussion}

Several authors recognize the need to tie the individual's cognitive processes to the environment where s/he is embedded, as farmers' psychological characteristics are important 
non-economic elements of decision-making (Edwards-Jones, 2006; Manteleone, 2019). More interestingly, our work goes deeper to show that such attitudes, subjective norms, networks, and trust (general and institutional) are interconnected elements of two different frameworks that jointly explain farmers' intentions to perform a specific action. This finding provides insights into the associations among a large number of variables that individual models are not able to show (Klöckner, 2013). In this sense, TPB acts as a mediator to unveil a more complex interaction of interconnected internal (psychological) and external (institutional) factors that can help us understand the decision-making processes underlying adoption. Although we are aware that a model that incorporates all factors might not be feasible, our proposed model sheds light on important cognitive, social capital, and economic factors that affect adoption.

An additional contribution of our work is that it tests intention and actual behavior using a oneyear lifespan analysis. This approach is rare in the literature and even scarcer in decisions related to the agricultural sector. The results show that intention predicts actual behavior, and that modeling actual behavior enables testing both direct and indirect effects of interconnected variables, not only on intention but also on actual adoption. Farmers reported a positive attitude towards pressurized irrigation technology, believing that pressurized irrigation is profitable, improves crop management, and increases yields. This positive attitude indirectly affects adoption through intention. The impact of subjective norms on intention and its indirect effect on adoption is noteworthy, as is the fact that a farmer's perception of what others expect him/her to do is influenced by institutional trust. Farmers are keen to adopt technologies that others approve of; this is in line with the findings of Läpple and Kelley (2013), who showed that social norms and the ability and resources of the farmer limited the adoption of organic practices. Yet, the implications of social norms go beyond social acceptance. Social norms define what is acceptable or unacceptable, providing the basis for maintaining trust and, at the same time, such norms create an obligation to engage in mutual effort (Lyon, 2000).

Social capital provides access to more and better information (Jacques et al., 2018; Wuepper et al., 2018); hence, its inclusion, mediated through TPB variables, gives a sense of what is affected by this access to information. Being a member of an association provides access to information that can shape the willingness to adopt. In our results, membership directly impacts the intention to adopt the technology and indirectly affects actual adoption. This finding fills the gap identified by Prokopy et al. (2008), as our model provides evidence that membership has a positive and significant influence on intention. Our results also indicate that 34 
if the farmer trusts water community associations and water monitoring boards, it is more likely that he/she will have a higher intention to adopt modern irrigation technologies. Nonetheless, other studies have found that trust is negatively related to decisions regarding the adoption of irrigation technology and climate change adaptation ( Paul et al., 2016; Hunecke et al., 2017). Such contradictory results highlight the importance of understanding the relations of the elements of social capital and behavior on a case-by-case basis in order to design locally adapted policies. Overall, we can see that general and institutional trust, social norms, and membership are relevant in explaining adoption, directly or indirectly, through intention. Despite this, only $23 \%$ of the sample has had a role within local organizations. This represents an opportunity to design an intervention in which local organizations promote the engagement and active participation of farmers.

The influence of perceived control on intention is positive and significant in our model. An individual's belief in their capacity to execute the action will affect their behavioral intention. How confident a farmer is in adopting pressurized irrigation depends on the people around him/her who have adopted the technology, as shown by the influence of networks on perceived control. Social networks should be strengthened and used as an instrument to increase self-confidence levels among farmers. As Dowd et al. (2014) noted, strong networks make individuals feel more satisfied and confident with the amount of information they receive through their network. Social influences help shape a person's estimation of their confidence and capability to use a system well (Bhatti, 1970). We measured social networks, through membership and the number of farmers that have adopted, so strategies should focus on encouraging an increase in membership and in the creation of discussion forums that foster interaction and, therefore, enlargement of the network.

In the estimated model, we also included control variables focusing on the traditional economic incentives and restrictions that are part of the utility maximizing models. The results are indeed revealing. In general, other than physical capital, these variables do not have a significant effect on adoption, meaning that socio-psychological variables are capturing the effect they usually express in traditional models (Engler et al., 2016). Hence, more emphasis should be placed on developing a pro-adoption environment than on relaxing farmers' constraints, such as providing high subsidies to promote adoption.

Key policy implications can be derived from our empirical results. First, attitude campaigns are not enough to influence intentions. Therefore, policies introduced by governmental institutions 
could achieve better results by promoting long-term changes in beliefs and social norms. Even a policy without any financial incentive could result in more environmentally friendly and socially responsible behavior if it were designed to strengthen self-confidence and perceived social pressure (Czap et al., 2016). Second, initiatives from the government could define a strategy to change the current practice (the generally acceptable norm of traditional irrigation). Influencing farmers' core beliefs associated with water conservation awareness, and boosting farmers' trust in water organizations that could foster cooperation, could both lead to the adoption of pressurized irrigation systems as a norm (Klöckner, 2013). Third, extension services should focus on transferring knowledge and information through social networks to facilitate action and increase farmers' perceived self-confidence about undertaking the challenge of switching from superficial to pressurized irrigation. In this context, such as strategy is more important than improving attitudes towards the technology.

\section{Conclusions}

The objective of this study was to provide a comprehensive understanding of the farmers' behavioral beliefs, and the effect of the social environment on such beliefs, to explain adoption decisions. We argued that understanding how attitudes, subjective norms, and perceived control affect the intention of adoption is not enough to provide useful insights for policy. In doing so, we proposed an integral framework that includes the cognitive components of TPB and is extended by social capital variables. Our results provide novel insights into the decisionmaking process, and they raise several points that can expand this line of research. First, decisions are a result of a dynamic process, and although we capture two points in time (individual intention and action), it would be interesting to analyze the changes in beliefs and/or social aspects in order to measure the indirect and direct effect on adoption of such aspects. Second, as the triggers of decisions are already in motion, we could also explore the impact of TPB and social capital on incremental adoption. Having a better understanding of the adoption path of the farmers could lead to proposing more purposeful policy incentives to increase the speed of adoption by farmers. 


\title{
Chapter 3. Social capital and conservation under collective and individual incentive schemes: a framed field experiment in Indonesia
}

\author{
Gracia Maria Lanza Castillo ${ }^{1}$, Marcela Ibañez ${ }^{2}$, Meike Wollni ${ }^{1}$, Miriam Vorlaufer ${ }^{3}$ \\ ${ }^{1}$ Department of Agricultural Economics, George August University \\ ${ }^{2}$ Research Centre, Equity, Poverty and Growth, Georg-August-University Göttingen \\ ${ }^{3}$ UNIQUE Forestry and Land Use
}

\begin{abstract}
In this study, we explore the effects of payments for environmental services on land use decisions among farmers living in Jambi province in Indonesia. Using a framed field experiment we compare land use decisions in a baseline with no payment with two alternative payments for environmental services (PES): an individual incentive scheme, where each participant receives a flat rate payment for each experimental land unit conserved, and a collective incentive scheme that offers individual payments only if an aggregate predetermined conservation threshold is passed by the group. We find that individual and collective PES are equally effective to increase environmentally friendly behavior associated with the cultivation of rubber agroforestry. Yet we find that whereas collective incentives work equally well for small and large farmers, individual incentives only work for small farmers. In addition, collective incentives generate an increase in conservation even at low payment levels whereas individual incentives only work when payments are high. Participants with a larger social network cultivating oil palm invest a lower share of their endowment in conservation. These findings highlight how land heterogeneity and social capital influence the success of a PES scheme.
\end{abstract}

Keywords: social capital, payment for environmental services, agroforestry, incentives for conservation

The author's contribution is as follows: MI, MW and MV designed the experiment. MV collected the data. GL MI and MW analyzed and interpreted the data. GL MI and MV wrote the paper. . 


\section{Introduction}

Over the last two decades, payments for environmental services (PES) have become a common environmental policy instrument to promote conservation (Le Velly and Dutilly 2016). PES are defined as a voluntary transaction where a buyer buys a well-defined ecosystem service from a service provider if and only if the provider secures its provision (Engel 2016; Engel, Pagiola, and Wunder 2008). Due to the high cost of implementing command and control measures and weak institutions in developing countries, this policy instrument is regarded as being more effective than command and control instruments (Le Velly and Dutilly 2016; Narloch, Pascual, and Drucker 2012; Pagiola, Arcenas, and Platais 2005; Porras and International Institute for Environment and Development. 2010; Wunder and Borner 2011).

Recent systematic reviews suggest that PES reduce deforestation rates, although the effect is relatively modest (Samii et al. 2014; Börner et al. 2017; Adhikari and Agrawal 2013). Experimental evidence supports this finding; e.g., offering payments to forest owners in Uganda for not cutting down their trees led to decreased deforestation rates (Jayachandran et al. 2017; DeFries 2017). However, one concern that remains is how to bundle small individual contracts into one larger agreement to have a complete landscape coverage and to reduce transaction cost (Kerr, Vardhan, and Jindal 2014; Ramirez-Reyes et al. 2018). Individual payments do not explicitly promote the coordination among suppliers to conserve, contiguous land parcels and hence potentially result in low ecological services.

An alternative to overcome this problem is to use a collective incentive scheme, where individual service providers receive a payment only if a minimum level of conservation is achieved at the group level (Kerr, Vardhan, and Jindal 2014; Dickman, Macdonald, and Macdonald 2011).

However, uncertainty on whether the threshold can be trespassed and the possibility for freeriding behavior might decrease the effectiveness of collective schemes compared to an individual payment scheme. For example, Narloch et al (2012) identified that collective incentives affect positively conservation outcomes but its effect was undermined due to freeridding behavior. 
Social norms are understood as key when implementing payment for environmental services (Clements et al. 2010; Grima et al. 2016; Midler et al. 2015; Muradian et al. 2010; Narloch, Pascual, and Drucker 2012). Pretty (2003) argues that where there is a strong social norm, individuals have confidence to invest in pro-social activities, knowing that others will do so too. Middler et.al. (2015) identified that collective incentives have a positive effect on conservation only when social ties are strong.

In this paper, we investigate the effectiveness of individual versus collective payment schemes in promoting conservation using a framed field experiment. We assess the response to PES schemes and disentangle heterogeneous effects of individual and collective schemes. In addition, we explore to what extend the behavior of others, or the unwritten social norms, help to enhance conservation under under individual and collective incentive schemes.

As case study, we focus on Indonesia which has the third largest area of tropical rainforest in the world after the Amazon and Congo Basins (Fitzherbert et al. 2008). Despite its reputation as a global biodiversity hotspot, the country is also known as one of the top three greenhouse gas emitters from deforestation worldwide, partly due to the expansion of oil palm cultivation (Sloan, Edwards, and Laurance 2012; Carlson et al. 2012). It is estimated that 53 percent of the total area planted with oil palm in Indonesia is the result of deforestation since 1989 (Vijay et al. 2016). In response, the Government of Indonesia has started more than 60 REDD+ (Reducing Emissions from Deforestation and Forest Degradation) activities, being one of them the provision of monetary incentives to reduce land conversion and promote sustainable forest management (FCPF 2018). In this regard, this study provides insights on farmers' response to different PES schemes to foster environmentally friendly behavior associated with the cultivation of rubber agroforestry.

Our framed field experiment is based on Vorlaufer et al. (2017). Participants decide how to allocate their endowment of land between two alternative products commonly grown in the region: rubber agroforestry and oil palm plantations. Replicating actual trade-offs in the land allocation decisions, we set the experiment such that cultivation in oil palm yields higher returns than the cultivation of rubber agroforestry. Yet, to capture the effects that rubber agroforestry generates on the environment (e.g., soil conservation, biodiversity habitat, etc.), we allow positive externalities to the cultivation of rubber agroforestry. 
To examine how heterogeneity in endowments and in returns affects conservation decisions, we vary the endowment of land that individuals in a group receive. Two individuals are low endowed and receive 5 units of land and one individual is high endowed and receives 10 units. We extended this experiment to include a between subject design, where participants took identical land allocation decisions but under an alternative incentive schemes. The incentive was framed as Payment for Environmental Services aiming to foster environmentally friendly behavior associated with the cultivation of rubber agroforestry.

We experimentally vary two characteristics of the scheme. We implemented either an individual or collective incentive scheme and under each scheme we offered a low and a high incentive. Under the individual scheme, participants received the payment individually for each unit of endowment individually allocated to conservation. In the collective incentive scheme, participants received the incentive based on their individual allocation, but only once the total number of land units allocated to the conservation of rubber agroforestry at the group level reached a minimum threshold level.

We find a significant proportion of the endowment of land (40 percent) is devoted to rubber agroforestry. As expected farmers with high endowments invest a significantly larger fraction of their land endowments (52 percent) compared to low endowed individuals (45 percent) under individual schemes. We find that PES are effective at promoting conservation. However, the elasticity of supply is relatively low. A one percent increase in the payments leads to a 0.02 percent increase in the area conserved. Comparing individual and collective incentives, we find that they are equally effective at promoting conservation on the average.

There are many studies analyzing the effect of PES but relatively few studies exploring the response to individual and collective PES schemes. Midler et al. (2015) analyze collective and individual types of PES schemes with and without communication. Supporting the importance of social norms, they find that collective incentive promotes conservation only when social ties are strong (number of family members in the same session) or when communication was allowed. More recently, Kaczan et al (2017) showed that collective incentives increase the time contribution for conservation practices. We contribute to the literature by explicitly considering how heterogeneity in land endowments and the interaction of monetary incentives with network behavior affects farmer's pro-environmental behavior under PES schemes. 
There is limited literature concerning land use heterogeneity providing recommendations for the design of payments for environmental services. In terms of PES geographical focus, Eloy (2012) performed an analysis of land use heterogeneity in agricultural frontiers in the Amazonia showing that PES policies should focus on remote areas, where the initial stage of deforestation usually takes place, where the agro ecosystem fertility and agro biodiversity are already high and where farmers are younger and poorer (Eloy et al. 2012). With regards to response to incentives considering land heterogeneity, Vorlaufer et al. (2017) show that farmers with low land endowment (poor) reacted more strongly to PES than farmers with high endowment (rich). In the same line, Keser (2014) found that when there are strong asymmetries in endowment, high endowed (rich) participants contribute significantly lower percentage than low-endowed (poor) participants (Keser et al. 2014). Yet, these studies do not compare different PES schemes.

This paper also contributes to the literature studying the how social norms affect the effectiveness of PES. Barr et al (2012) study the role of trust, group membership and networks in an individual incentive scheme. They found that trust and group membership positively reinforce individual participation while the presence within a reciprocal fishing dependency network reduces the likelihood of participation. Similarly, Chen et. al. (2009) found that farmer's intention to re-enroll in the Grain-to-Green Program in China decreased if they observed reconversion to non-green technologies among their neighbors.

The paper is structured as follows: Section two provides background and context in terms of previous PES in Indonesia and the importance of the region. In Section three, we present the literature review on the empirical evidence about social norms and network, PES and environmental outcomes. Section four presents the theoretical framework of the investment game; followed by section five, where details of the empirical data are presented. In Section six, we present descriptive statistics followed by the econometric results. Finally, in Section seven, we discussed the implications of the findings at the policy level with regards to natural resources management initiatives in Indonesia and the design of PES in general. 


\section{Conceptual framework}

We consider the individual decision on land use. Each individual $i$ has $e_{i}$ units of land which we refer to as hectares. Their task is to decide how to allocate the endowment between oil palm and rubber agroforestry. We denote $r_{i}$ the number of units that are invested in rubber agroforestry and consider that the land that is not invested in rubber agroforestry is invested in oil palm $\left(e_{i}-r_{i}\right)$. Acknowledging the existence of multiple types of individuals as a core principle of modeling collective behavior (Ostrom 2007), we consider that producers are heterogeneous in terms of size of available land. Therefore, we have low-endowed individuals, $\mathrm{L}$, with $e_{L}$ units of land and high endowed individuals, $\mathrm{H}$, with $e_{H}$ units of land.

Consistent with the fact that the cultivation of rubber agroforestry generates positive environmental effects (i.e. host lowland biodiversity, carbon storage, improve water quality, among others) we consider that each unit invested in rubber agroforestry generates a positive externality, $\beta$, to the members of the group. In addition, consistent with the fact that rubber agroforestry has lower economic returns than oil palm (Djanibekov and Villamor 2017), we set the marginal return generated by each hectare of oil palm to 1 , while the marginal return from one hectare of rubber agroforestry is set to $\gamma<1$. We further allow different marginal returns for low and high-endowed individuals. We assume that low-endowed individuals are less productive in rubber-agroforestry than high-endowed individuals and set $\gamma_{L}<\gamma_{H}$..

To account for the possibility that individuals internalize the cost that cultivating oil palm generates to nature, similar to Ibanez and Martinsson (2010) we assume that individuals disutility from cultivating oil palm is $M=c_{i}\left(e_{i k}-r_{i K}\right)^{2}$ Where $c_{i}$ denotes a parameter that measures the importance that individual $i$ gives to conservation. For an individual who does not care about conservation, $c_{i}=0$. Whereas for an individual who gives importance to the environment $c_{i}>0$.

The individual's utility function $U_{i}$ is given by:

$$
U_{K i}=e_{i k}-r_{i K}+\gamma_{K} r_{i K}+\beta \sum_{j=1}^{n=2} r_{j}-c_{i}\left(e_{i k}-r_{i K}\right)^{2}
$$

where $K=\{L, H\}$.

Taking as given the investment decisions of others, $r_{j}$, the marginal incentive to invest in rubber agroforestry is: 


$$
\frac{d U_{i k}}{d r_{i K}}=-1+\gamma_{K}+2 c_{i}\left(e_{i k}-r_{i K}\right)
$$

Because the marginal return from oil palm is higher than from rubber agroforestry, the model predicts that an individual who does not care about conservation will allocate all the endowment to oil palm instead of rubber agroforestry $\left(r_{i}^{*}=0\right)$. Alternatively, for an individual who cares sufficiently about conservation such that $\frac{d U_{i k}}{d r_{i K}}=0$ we will have an interior solution where the investment in rubber agroforestry is:

$$
r_{i K}=\frac{2 c_{i} e_{i K}+\gamma_{K}-1}{2 c_{i}}
$$

Hence, the units of land in rubber agroforestry will increase as individuals give more importance to the environment, have more land endowments and have higher marginal return from cultivating rubber agroforestry. From this condition, we derive our first hypothesis:

H1. The proportion of land invested in rubber agroforestry is larger for high-endowed individuals compared to low endowed individuals.

The basic decision problem is extended to investigate the effectiveness of different institutional designs of PES. The first design that we consider is one in which PES are offered to each individual. For each unit of land invested in rubber agroforestry, participants receive $\gamma_{K}+P E S$. Individual's utility is:

$$
U_{K i}=e_{i k}-r_{i K}+\left(\gamma_{K}+\mathrm{PES}_{\mathrm{K}}\right) r_{i K}+\beta \sum_{j=1}^{n=2} r_{j}-c_{i}\left(e_{i k}-r_{i K}\right)^{2}
$$

As shown in Vorlaufer et al. (2017) an individual payment is predicted to increase the likelihood that an individual invests in rubber agroforestry. In addition, conditional on positive investments, PES increases the amount of endowment that individuals invest in agroforestry. For individuals who care about the environment, $\left(\frac{d U_{i k}}{d r_{i K}}=0\right)$, the marginal effect of an increase in PES is: 


$$
\frac{\mathrm{d} r_{i K}}{\mathrm{dPES}}=\frac{1}{2 c_{i}}
$$

Hence, the model predicts that the response to the incentive is independent on the endowment of land.

The second design considers a collective incentive. Under this scheme, $n$ community members receive a payment PES conditional on achieving a specified target level of conservation. If the total area conversed by the community is larger than a pre-specified threshold $T\left(\sum_{i=1}^{n} r_{i K} \geq T\right)$ the individual $i$ receives the incentive independently on her conservation decisions. In this case, $\sum_{i=1}^{n} r_{i K} \geq T$ individual's utility is given by Equation Error! Reference source not found.. If the threshold is not reached, no community member receives the payment. In this case individual's utility is given by Equation Error! Reference source not found.. Participants expected utility of investing in rubber agroforestry depends on the subjective probability, $p_{i}$, that individual assigns that the group reaches the threshold level. We assume that individuals have rational expectations and that the expected probability depends on individual's experience on how much community members invest in rubber agroforestry.

It is straightforward to show that compared with the individual incentive, collective incentives have a lower effect on the likelihood that individuals invest in rubber agroforestry and the amount of land that is devoted to rubber agroforestry. The marginal effect of PES for individuals who do cultivate rubber agroforestry concerns is:

$$
\frac{\mathrm{d} r_{i K}}{\mathrm{dPES}_{K}}=\frac{p_{i}}{2 c_{i}}
$$

Based on this extension of the basic model we derive the following hypotheses:

$\mathrm{H} 2$ : Under collective incentives the effect of PES on conservation would be lower than under individual incentives. The effect of PES is independent of endowment of land. 
H3. Conservation behavior is dependent on the individual's expected investment of network members. As more network members cultivate rubber agroforestry, more land is allocated to rubber agroforestry under collective incentives but not under individual incentives.

\section{Background}

Indonesia spreads over more than 18,000 islands; with around $60 \%$ of the territory being located in tropical rainforest. Due to the high levels of endemic species and rich biodiversity, this country is of worldwide environmental importance (Waltert, Mardiastuti, and Mühlenberg 2004). Oil palm plantations cover approximately 8 million hectares in Indonesia and it is expected that they will reach about 13 million hectares by 2020 (Cacho et al. 2014). The establishment of oil palm and timber plantations have now become the main drivers of deforestation in Indonesia (Cacho et al. 2014; Koh and Wilcove 2008). The increasing world demand for crude palm oil and the national policies on biofuels requiring either ethanol or palm-oil biodiesel in the fuel mix suggest that expansion of oil palm plantations will continue (Dillon et al. 2008). Much of the production in Indonesia comes from large-scale plantations, however, independent smallholders are increasing their share and may dominate production in the future.

PES are regarded as a promising policy instrument to foster conservation and promote alternative agroforestry systems such as rubber agroforest (Engel, Pagiola, and Wunder 2008; Muradian et al. 2010; Muradian 2013; Börner et al. 2017). Rubber agroforest represents a traditional, extensive management system, which is established by inter-planting rubber trees with native fruit and timber trees. Rubber agroforest can rapidly develop a vegetation structure close to that of secondary forest of similar age (Ekadinata, Widayati, and Vincent 2004) and therefore generates positive environmental effects (i.e. improved water quality, increased soil fertility and higher biodiversity).

Indonesia has implemented PES instruments to promote the provision of water and carbon sequestration services in the Bungo watershed and Lake Singkarak (Adhikari and Agrawal 2013). Farmers who protect upper watersheds and avoid planned deforestation or increase tree planting have benefited from these schemes (Kerr, Vardhan, and Jindal 2014; Lapeyre, Pirard, and Leimona 2015; Suich et al. 2017). Under this scheme, the community leaders certify compliance with conservation goals. The success of the mechanisms has been associated with increased coordination by publically agreeing expected behavior. 46 
Furthermore, social sanctions for not compliance are expected to foster compliance (Coleman 1987).

Kerr et al (2014) examined the "Hutan Kamasyarakatan (HKm) Social Forestry Program", which offered an in-kind individual incentive (probationary land right) in exchange for watershed protection. Participation was on a voluntary basis but required individuals to be part of an organized group, which guaranteed compliance at the individual level. The Social Forestry Program was considered a success because most farmers did not have land security and the option of having a provisional land right was incentive enough to protect the watershed; in addition, farmers had the possibility to extend this land right permit for a 25-year period after the first five years. Nowadays, land rights have been granted for longer period (25 years) and are no longer an in-kind incentive.

The result of this study are particularly relevant as the Indonesian Government has started more than 60 REDD+ (Reducing Emissions from Deforestation and Forest Degradation) activities, being one of them the provision of monetary incentives to reduce land conversion and promote sustainable forest management (FCPF 2018). In our study area, the Jambi province, these incentives are yet to be implemented.

To the best of our knowledge there are no studies that analyze the conservation outcomes of collective schemes under different payment levels and therefore this study provides insights on farmers' response to different PES schemes to foster environmentally friendly behavior associated with the cultivation of rubber agroforestry.

\section{Experimental design and procedure}

The experimental design aims at testing the effectiveness of different institutional designs of PES to foster conservation decisions. We formed random and anonymous groups of three participants $(n=3)$. Two participants in the group were randomly assigned to receive an endowment $e_{L}=5$ and one participant received $e_{H}=10$. The participants' task was then to decide how to allocate their endowment between oil palm and rubber agroforestry. The scenarios reproduce the investment decision presented in the theoretical model $\left(\gamma_{L}<\gamma_{H}<\right.$ 1). Considering the estimates by Feintrenie et al. (2010) of rubber agroforestry and oil palm 
productivity in Jambi province, we set the marginal return of rubber agroforestry of lowendowed participants to $\gamma_{L}=0.5$, and for high-endowed participants to $\gamma_{H}=0.6$.

Participants were explained about the positive externalities of rubber agroforestry and how this system contributes to habitat for biodiversity, carbon sequestration. In our experiment, we emphasize that by their decision on allocating hectares to rubber agroforestry they will be benefiting group members. Assigning a value to the externality is challenging due to the complex relationships between land management, biodiversity and fluctuations in ecological services, (Pascual and Perrings 2007). As far as we are aware, there is no economic valuation of the effects of rubber agroforestry on the environment. For the experiment, we let each experimental unit of land cultivated with rubber agroforestry generate a value of $\beta=0.2$.

In the experiment we use a between-within subject design that varies the type of incentive scheme and the payment level across two payment sets (Table 4). In the within subject design, each participant was presented with three decisions that vary the value of the incentive. In the first decision the incentive is set to zero (baseline without PES); the second and third decisions correspond to either a low or a high incentive depending on the order randomly pre-determined for the session. In the between subject design, we tested two different types of PES, individual and collective, and implemented two different payment sets. While under the individual incentive scheme, participants received a flat-rate payment for each experimental land unit allocated to rubber agroforestry, under the collective scheme, payment is conditional on the achievement of an aggregate conservation threshold. We set the threshold level at $T=7$, corresponding to $35 \%$ of the aggregate land endowment at group level. Table 4 presents an overview of the parameters used in the experiment.

Table 4. Parameters used and participants in the experiment by treatment and endowment status

\begin{tabular}{|c|c|c|c|c|c|c|c|c|c|}
\hline \multirow[t]{2}{*}{ Treatments } & \multirow{2}{*}{$\begin{array}{c}\text { Endowmen } \\
\mathrm{t}(e)\end{array}$} & \multirow{2}{*}{$\begin{array}{l}\text { Marginal } \\
\text { per capita } \\
\text { return }(\gamma)\end{array}$} & \multicolumn{2}{|c|}{ PES Set 1} & \multicolumn{2}{|c|}{ PES Set 2} & \multirow{2}{*}{$\begin{array}{c}\text { Positive } \\
\text { externalities } \\
(\beta)\end{array}$} & \multicolumn{2}{|c|}{ Total } \\
\hline & & & $P E S_{L}$ & $P E S_{H}$ & $P E S_{L}$ & $P E S_{H}$ & & $\begin{array}{c}\text { Participant } \\
\mathrm{s} \\
(\mathrm{N}=246) \\
\end{array}$ & $\begin{array}{c}\text { Group } \\
\mathrm{s} \\
(\mathrm{N}=82) \\
\end{array}$ \\
\hline \multirow{2}{*}{$\begin{array}{l}\text { Individual } \\
\text { Incentive }\end{array}$} & $e_{L}=5$ & $\gamma_{L}=0.5$ & 0.05 & $\begin{array}{c}0.2 \\
5\end{array}$ & 0.1 & 0.3 & 0.2 & 88 & 22 \\
\hline & $e_{H}=10$ & $\gamma_{H}=0.6$ & 0.05 & $\begin{array}{c}0.2 \\
5\end{array}$ & 0.1 & 0.3 & 0.2 & 44 & 22 \\
\hline \multirow[t]{2}{*}{$\begin{array}{l}\text { Collective } \\
\text { incentive }\end{array}$} & $e_{L}=5$ & $\gamma_{L}=0.5$ & 0.05 & $\begin{array}{c}0.2 \\
5\end{array}$ & 0.1 & 0.3 & 0.2 & 76 & 18 \\
\hline & $e_{H}=10$ & $\gamma_{H}=0.6$ & 0.05 & $\begin{array}{c}0.2 \\
5\end{array}$ & 0.1 & 0.3 & 0.2 & 38 & 20 \\
\hline
\end{tabular}


The experiment was implemented from November 2012 until March 2013. The participants were randomly invited to participate in the experiment based on a village census. At the start of the session, the instructions of the game were read aloud to the participants, followed by several examples. To improve understanding of the rules of the game, we worked with visualizations and to illustrate investment decisions, participants were presented with pictures from oil palm and rubber agroforestry systems. The endowment with experimental land units was represented by color stickers. After completion of two practice rounds, the actual experiment was carried out. Participants did not receive feedback on investment decisions of other group members and communication was not allowed throughout the session.

In total 30 experimental sessions were carried out, 16 with the individual incentive scheme and 14 with the collective incentive scheme. Each experimental session had between 2 and 3 groups, with a total of 246 participants and 82 groups from which 44 groups participated in the individual incentive scheme and 38 in the collective incentive scheme. On average, participants earned $86,347 \mathrm{Rp}$, which is equivalent to one to two daily wages in the research area. A post experimental questionnaire was applied to gather information concerning individual socio-economic characteristics, perception of fairness towards the payment, reasons behind their decision on planting oil palm and rubber agroforestry, number of family members that participated in the same session, number of participants in the same session known by name, and the number of participants in the same session with whom the participant has interacted in the last month.

In addition, as illustrated in Equation Error! Reference source not found. the subjective probability, $p_{i}$, that individual assigns depends on the individual's experience on how much community members invest in rubber agroforestry. In order to capture individual's experience on how much its community invest in rubber agroforestry, a socioeconomic survey including questions with regard to social norms and network was performed. The survey applied the random matching within sample technique (Maertens and Barrett, 2013), where each farmer was matched with nine randomly drawn individuals from the sample in each village and, for each match, we elicit details of the relationship between the farmer and the match. Based on Conley and Udry (2001) and Maertens and Barrett (2013), we include questions such as: do you know farmer $X$ ?, when did you last talk with $X$ ?, in a normal month, how often do you talk to $X$ ?, Does $X$ plant oil palm, rubber monoculture or rubber agroforest? and how many hectares does $X$ cultivate?. Since the matching was random, these measures give us an 
indication of the farmer's social connectedness within the community and his perceptions regarding the cultivation activities of his social network members. We use the responses to these questions to capture the subjective probability that the farmer attaches to other community members investing in rubber agroforestry.

\section{Estimation approach}

In order to analyze the effect of individual and collective schemes on conservation behavior, we define as dependent variable the share of the total endowment allocated to rubber agroforestry. Thus, the model we estimate is the following:

$$
Y_{i t}=\beta_{0}+\beta_{T} T_{i}+\beta_{P E S} P E S_{i t}+\beta_{T x P E S}\left(T_{i} x P E S_{i t}\right)+X_{i}^{\prime} \beta+S_{i}^{\prime} \beta+u_{i}+v_{i t}
$$

Where, $Y_{i t}$ is the conservation outcome by participant $i$ in decision $t . T$ is a dummy that takes value equal to one if the collective scheme was implemented and zero otherwise, PES is the value of the incentive that was offered to participants $(0.05,0.10,0.25,0.30)$. Our coefficient of interest is $\beta_{\text {TXPES }}$. Our hypothesis is that this coefficient is negative indicating that participants respond less to the collective than to the individual incentive. The vectors $X$ and $S$ represent socioeconomic characteristics and social norm and network variables, while $u_{i}$ stands for the idiosyncratic error term and $v_{i t}$ is the residual. With regards to $S_{i}{ }^{\prime}$ we include the characteristics of the farmer's network with regards to the aggregate level of environmental connectedness from his/her network, number of people from his/her network that cultivates rubber agroforestry and number of people from his/her network that cultivates oil palm. In addition we consider how much weight a farmer gives to act like others and to comply with the social norm. We expect that farmers refer to their social network to derive predictions on how their group members will behave and what the social norm is; for example, a farmer with a larger network cultivating oil palm is expected to invest less in rubber agroforestry under the collective incentive scheme (Hypothesis 3 ) while it should not affect investment under the individual PES.

To disentangle heterogeneous effects by land-endowment we define as dependent variable the individual share of the total endowment allocated to rubber agroforestry. Thus, the model we estimate is the following: 


$$
Y_{i}=\beta_{0}+\beta_{P E S} P E S_{i}+\beta_{K x E S}\left(K_{i} x P E S_{i t}\right)+X_{i}^{\prime} \beta+S_{i}^{\prime} \beta+u_{i}+v_{i t}
$$

Where, $Y$ is the conservation outcome by participant $i . K$ is a dummy that takes value equal to one if the individual was endowed with ten hectares and zero otherwise, PES is the value of the incentive that was offered to participants $(0.05,0.10,0.25,0.30)$. Our coefficients of interest are $\beta_{E S}$ and $\beta_{K X P E S}$ which compare the response of low and high endowed individuals to PES, respectively. Our hypothesis is that $\beta_{P E S}$ will be positive. The model predicts that $\beta_{K X P E S}$ will be not significantly different from zero, indicating that low and high endowed individuals react similarly to PES. The vectors $X$ and $S$ represent socioeconomic characteristics and social norm and network variables, while $u_{i}$ stands for the idiosyncratic error term and $v_{i t}$ is the residual.

To account for the panel structure of the data, we estimate a Generalized Least squares (GLS) random effects model. Although our dependent variable ranges between 0 and 1 , it is distributed normally justifying the use of this model.

\section{Results}

\subsection{Descriptive statistics}

From the total sample of farmers, $54 \%$ were assigned to the individual incentive scheme and $46 \%$ to the collective incentive scheme. The socioeconomic characteristics of the participants in the study are comparable across villages. The balance across sample for individual and collective treatment shows no significant differences with regards to age, education and size of the farm. Farmers are on average 43.78 years old with successful completion of elementary school (six years of education) but have not finalized secondary school (Table 5). Participants of the two treatments do not differ in terms of area of oil palm cultivated and the size of the farm. The crop that is cultivated more commonly by the participants is oil palm, followed by rubber and small portion with rubber agroforestry. On average 86 percent of the participants have as main occupation agriculture.

The results of the random matching within sample technique showed that farmers on the average know four people that cultivate rubber agroforestry and six people that cultivate oil palm; the level of education of the network is on average 7.45 years of schooling. In general, 
the network has the same pattern of cultivation, being oil palm the predominant crop, followed by rubber and in small proportion jungle rubber.

Table 5. Summary Statistics and balance check

\begin{tabular}{|c|c|c|c|c|c|}
\hline \multirow[b]{2}{*}{ Variables } & \multirow[b]{2}{*}{ Mean } & \multirow[b]{2}{*}{ S.D. } & \multicolumn{3}{|c|}{ Balance across sample ${ }^{1}$} \\
\hline & & & $\begin{array}{c}\text { Individual } \\
\text { Treatment } \\
\text { (Mean) }\end{array}$ & $\begin{array}{c}\text { Collective } \\
\text { Treatment } \\
\text { (Mean) }\end{array}$ & p-value \\
\hline Age & 43.79 & 11.01 & 43.73 & 43.88 & 0.51 \\
\hline Sex (=1 if female) & 0.06 & 0.24 & 0.05 & 0.08 & 0.48 \\
\hline Education (=years of schooling) & 7.70 & 3.73 & 7.65 & 7.75 & 0.48 \\
\hline Size of the farm (has) & 3.84 & 6.00 & 3.21 & 4.65 & 0.47 \\
\hline $\begin{array}{l}\text { Area of oil palm cultivated by the participant } \\
\text { (has) }\end{array}$ & 2.35 & 3.46 & 1.98 & 2.78 & 0.46 \\
\hline $\begin{array}{l}\text { Area of rubber agroforestry cultivated by the } \\
\text { participant (has) }\end{array}$ & 0.33 & 1.91 & 0.31 & 0.34 & 0.48 \\
\hline Main occupation ( $=1$ if it is agriculture else 0 ) & 0.86 & 0.35 & 0.88 & 0.82 & 0.53 \\
\hline Individual environmental perception & 0.81 & 0.39 & 0.83 & 0.79 & 0.52 \\
\hline Family members in the same session & 1.03 & 1.68 & 1.20 & 0.83 & 0.55 \\
\hline People known by name in the same session & 7.24 & 1.50 & 7.53 & 6.91 & 0.00 \\
\hline $\begin{array}{l}\text { People with whom the participant speaks at } \\
\text { least once per month in the same session }\end{array}$ & 3.80 & 2.54 & 4.08 & 3.53 & 0.33 \\
\hline Social rubber agroforestry network & 4.47 & 3.13 & 4.41 & 4.52 & 0.82 \\
\hline Social oil palm network & 6.83 & 2.02 & 6.81 & 6.88 & 0.76 \\
\hline Environmental connectedness of the network & 5.53 & 1.01 & 5.49 & 5.59 & 0.59 \\
\hline $\begin{array}{l}\text { Stated commitment to comply and be } \\
\text { consistent with the social norm (=1 if yes) }\end{array}$ & 0.70 & 0.45 & 0.73 & 0.68 & 0.53 \\
\hline
\end{tabular}

In addition, we observed high environmental connectedness of the network (5.53 out of 7 ) and around 70 percent of the participants stated that they have and will behave to comply and be consistent with the social norm.

The response from the participants in the experiment at the group level is displayed in Figure 3. The figure shows the mean share allocated to conservation at the group level by treatment and payment set. The lines represent the confidence intervals. There are initial differences in the share allocated to conservation among payment sets for individual payments (Wilcoxon rank-sum test, $p<0.10)$. This suggests that in the econometric analysis we need to control for payment set. We also find that the share conserved increases with higher PES. Figure 3 shows that at baseline (no incentive), on average 40 to 48 percent of the land is invested in 
conservation. The share increases when participants are offered a PES, at low incentives, 0.05 and 0.10 , the share increases by 4.5 percent and high incentives, 0.25 and 0.30 , the share increases by 6.5 percent compared to the average of the baseline respectively.

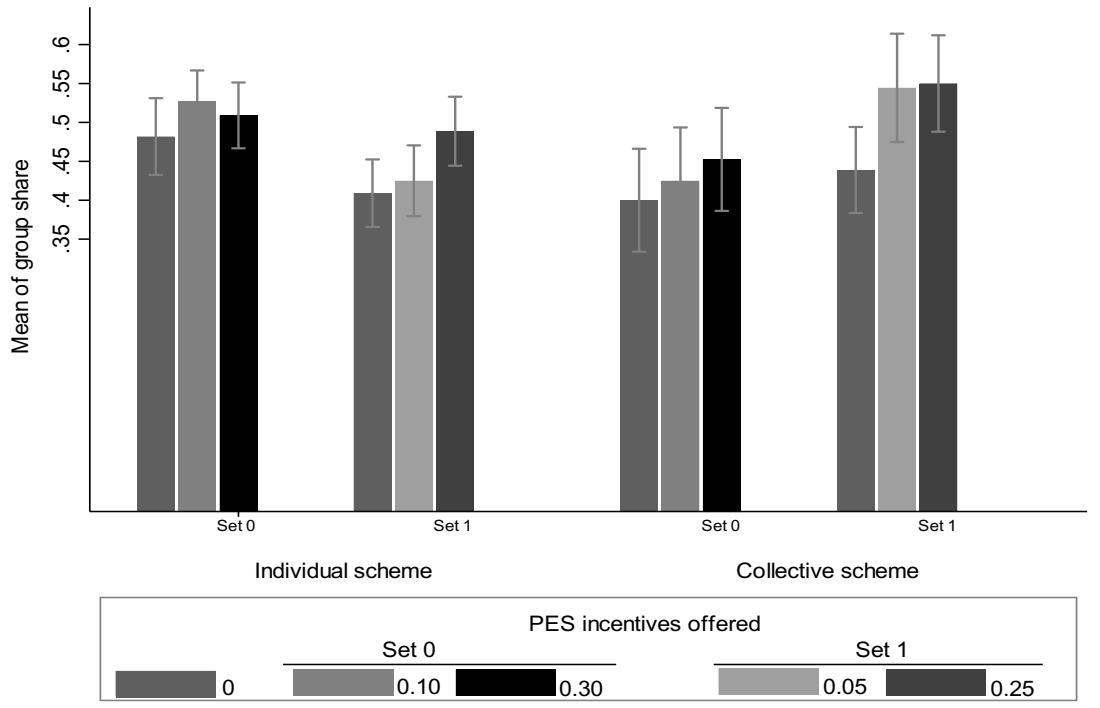

Figure 3. Mean group share allocated to conservation

\subsection{Collective versus individual scheme}

To test the effect of individual and collective schemes on conservation behavior we analyze the proportion of total endowment allocated to rubber agroforestry at the group level (Group share). We estimate equation 8 for the pooled sample controlling for session dummies with clustered standard errors at the session level (Table 6). We find that when there are no incentives 45 percent of endowment is invested in rubber agroforestry. This indicates that participant have high concerns for the environment, assigning a high moral cost from investing in oil palm. PES has a positive although small effect on conservation.

Table 6. Random effects GLS estimation for share of land conserved at the group level conserved

\begin{tabular}{lcc} 
& & S.E. \\
\cline { 2 - 3 } PES Incentive & Coef. & 0.001 \\
Treatment (=1 if collective) & $0.002^{*}$ & 0.056 \\
Collective * PES incentive & -0.013 & 0.001 \\
Constant & 0.000 & 0.028 \\
\hline $\mathrm{N}$ & $0.453^{\star * *}$ & \\
chi2 & 246 & \\
$\mathrm{P}$ & 8.494 & \\
Linear combination & 0.037 & \\
\hline
\end{tabular}




\begin{tabular}{|c|c|c|}
\hline PES Incentive + Collective ${ }^{*}$ ES incentive & $0.002^{\star *}$ & 0.0010 \\
\hline
\end{tabular}

${ }^{\star} p<0.1,{ }^{* *} p<0.05,{ }^{* \star *} p<0.01$

A one percent increase in incentives increases investments in rubber agroforestry by 0.17 percentual points under individual incentives and by 0.23 percentual points under collective incentives. Yet, as indicated by the coefficient on the interaction term, this difference is not statistically significant. Hence we reject $\mathrm{H} 2$ stating that the elasticity of supply to PES is lower under collective than under individual incentive schemes. This unexpected result could indicate that individual asign a high probability or receive the incentive under collective incentive, or that they expect that the other participants would invest sufficiently in rubber agroforestry to receive the PES.

\subsection{Heterogeneous effects}

There has been little attention to asymmetry in endowment in the experiments when analyzing individual or collective PES schemes. The opportunity costs of allocating scarce resources to conservation are often significant for resource users with limited endowments (Narloch, Pascual, and Drucker 2012), as is the case for our low-endowed participants. In this study, we test whether conservation behavior under individual and collective schemes differs by endowment level (Table 7). For this purpose, we estimate equation 9 separately by individual and collective scheme and interacted endowment level with the PES incentive (model 2 and $3)$.

Results from model 2 show that in the absence of PES, individuals with high endowment of land invest a larger proportion of the endowent in rubber agroforestry. Yet, the results of model 3, indicate the opposite. Therefore we reject Hypothesis 1, stating that individuals with larger endowments invest a larger proportion of land in conservation.

Model 2 indicate that payments significantly increased conservation among low endowed participants. Yet the elasticity is relatively small and a one percent increase in PES increases the endowment invested in rubber agroforestry in only 0.3 percentual points $(p<0.1)$. In contrast, among high endowed participants the effect, given by the linear combination of coefficients is in fact not significantly different from zero $(p>0.10)$ as predicted by the model.

Under the collective scheme, PES significantly increases conservation among low endowed participants, although the size of the effect is small. A one percent increase in PES increases 54 
land conserve in only 0.1 percentual points $(p<0.05)$. The effect of PES on land conservation from high endowed participants is slightly larger $(0.3$ percentual points, $p<0.10)$. Thus, the results indicate that the two types of PES schemes have the same effect on participants with different land endowments.

Table 7. Random effect GLS estimation of individual share of land allocated to rubber agroforestry

\begin{tabular}{|c|c|c|c|c|c|c|c|c|}
\hline \multirow[t]{2}{*}{ Variables } & \multicolumn{2}{|c|}{$\begin{array}{c}(2) \\
\text { Individual } \\
\text { scheme }\end{array}$} & \multicolumn{2}{|c|}{$\begin{array}{c}(3) \\
\text { Collective } \\
\text { Scheme }\end{array}$} & \multicolumn{2}{|c|}{$\begin{array}{c}(4) \\
\text { Individual } \\
\text { scheme }\end{array}$} & \multicolumn{2}{|c|}{$\begin{array}{c}(5) \\
\text { Collective } \\
\text { Scheme }\end{array}$} \\
\hline & Coef. & S.E. & Coef. & S.E. & Coef. & S.E. & Coef. & S.E. \\
\hline $\begin{array}{l}\text { Endowment (=1 if } \\
\text { 10has) }\end{array}$ & $0.110^{*}$ & 0.059 & $-0.119^{*}$ & 0.075 & 0.091 & 0.057 & -0.082 & 0.074 \\
\hline PES Incentive & $0.003^{*}$ & 0.002 & $0.001^{*}$ & 0.001 & & & & \\
\hline $\begin{array}{l}\text { High-endowed } X \\
\text { PES incentive }\end{array}$ & -0.002 & 0.002 & 0.003 & 0.002 & & & & \\
\hline Level of PES & & & & & & & & \\
\hline Low (0.05-0.1) & & & & & 0.027 & 0.021 & $0.066^{* * *}$ & 0.021 \\
\hline High $(0.25-0.30)$ & & & & & $0.066^{* *}$ & 0.029 & $0.076^{* * *}$ & 0.020 \\
\hline $\begin{array}{l}\text { Constant } \\
\mathrm{N}\end{array}$ & $\begin{array}{c}0.352^{* *} \\
382\end{array}$ & 0.145 & $\begin{array}{c}0.329 \\
306\end{array}$ & 0.234 & $\begin{array}{c}0.356^{* *} \\
382\end{array}$ & 0.147 & 0.285 & $\begin{array}{c}0.236 \\
382\end{array}$ \\
\hline & & & & & & & 306 & \\
\hline chi2 & 49.92 & & 30.007 & & 27.274 & & 34.228 & 27.274 \\
\hline $\mathrm{P}$ & 0.000 & & 0.001 & & 0.002 & & 0.000 & 0.002 \\
\hline
\end{tabular}

To analyze if the effectiveness of the two schemes is conditional on whether high or low incentives are offered ${ }^{9}$ we aggregate the average share of land from the two lower $(0.05$ and $0.1)$ and from the two higher $(0.25$ and 0.30$)$ discrete PES offered. The results indicate that under the individual scheme low incentives were not sufficient to alter the farmer's behavior in comparison with the baseline (no incentive scenario). However, high incentives increase the individual share of land allocated to rubber agroforestry by 6.1 percentual points compared to the baseline. This means that although conservation levels can be achieved with individual schemes higher payment levels are required to motivate the farmer to engage in the scheme.

\footnotetext{
${ }^{9}$ As mentioned in the experimental procedure, we offer four discretional PES levels $0.05,0.1,0.25,0.30$.
} 
In contrast, low incentives under the collective scheme have a positive and significant influence on conservation behavior increasing the share of land allocated to rubber agroforestry by 6.0 percentual points. High incentives also have a significant and positive effect under the collective scheme, although the size of the effect (6.8 percentual points) is not much larger than with low incentives. Thus, as regards cost-effectiveness, collective incentives may offer the opportunity to achieve similar conservation outcomes at lower cost.

\subsection{PES interaction with social norm and network characteristics}

Social interactions are critical within collective processes (Kaczan et al. 2017), in this regard we analyze the effect of the participants' network characteristics and the stated disposition to act according to the social norm and their interaction with the incentives. Table 8 shows that characteristics related to the participant's social network have a significant influence on the conservation behavior mainly under the collective scheme, supporting Hypothesis 3 . Individual characteristics are more prominent when PES area offered under individual schemes.

Under the collective scheme, we observed the size of the social agroforestry network and the environmental perception of the network having a positive effect, increasing the share of land conserved by 24 and 6 percentual points respectively. In addition, we observe the negative effect of having a large oil palm network and a high compliance with the norm, implying that an additional person in the social oil palm network of the participant reduces the share of land allocated to rubber agroforest by 4 percentual points and the more willing a participant is to comply with what the social norm establishes, his contribution is reduced by 16 percentual points. This negative effect could be explain in two ways: 1) participants want to perform as the social norm in the area, which is the cultivation of oil palm and feel pressure to comply with the norm; and 2) in real life, individuals consider the behavior of others to predict the probability of conservation from the group members.

Table 8. Random effect GLS estimation of individual share of land allocated to rubber agroforestry

\begin{tabular}{|c|c|c|c|c|}
\hline \multirow{3}{*}{ Variables } & \multicolumn{2}{|c|}{ (6) } & \multicolumn{2}{|c|}{ (7) } \\
\hline & \multicolumn{2}{|c|}{ Individual } & \multicolumn{2}{|c|}{ Collective } \\
\hline & Coef. & S.E. & Coef. & S.E \\
\hline PES incentive & -0.00536 & $\begin{array}{l}0.00 \\
4\end{array}$ & 0.00483 & $\begin{array}{l}0.00 \\
6\end{array}$ \\
\hline Endowment ( $=1$ if 10 hectares) & $0.10839^{*}$ & $\begin{array}{l}0.09 \\
6\end{array}$ & -0.04136 & $\begin{array}{l}0.12 \\
2\end{array}$ \\
\hline
\end{tabular}




\begin{tabular}{|c|c|c|c|c|}
\hline \multirow{3}{*}{ Variables } & \multicolumn{2}{|c|}{ (6) } & \multicolumn{2}{|l|}{ (7) } \\
\hline & \multicolumn{2}{|c|}{ Individual } & \multicolumn{2}{|c|}{ Collective } \\
\hline & Coef. & S.E. & Coef. & S.E \\
\hline \multicolumn{5}{|l|}{ Individual characteristics } \\
\hline Individual environmental perception & $0.10671^{* * *}$ & $\begin{array}{l}0.03 \\
9\end{array}$ & -0.05551 & $\begin{array}{l}0.05 \\
8\end{array}$ \\
\hline Jungle rubber cultivated by the participant & $0.01904^{* * *}$ & $\begin{array}{l}0.00 \\
7\end{array}$ & $0.03780^{* * *}$ & $\begin{array}{l}0.01 \\
5\end{array}$ \\
\hline \multicolumn{5}{|l|}{ Social network characteristics } \\
\hline Social Agroforestry network & 0.19523 & $\begin{array}{l}0.19 \\
7\end{array}$ & $0.24918^{* * *}$ & $\begin{array}{l}0.07 \\
3\end{array}$ \\
\hline Compliance with the social norm (normative social influence) & -0.09740 & $\begin{array}{l}0.07 \\
8\end{array}$ & $-\overline{0.16948^{* * *}}$ & $\begin{array}{l}0.04 \\
6\end{array}$ \\
\hline Environmental perception of the network & -0.01207 & $\begin{array}{l}0.02 \\
3\end{array}$ & $0.06471^{*}$ & $\begin{array}{l}0.03 \\
8\end{array}$ \\
\hline Social Oil palm network & $-0.02568^{* *}$ & $\begin{array}{l}0.01 \\
1\end{array}$ & $-0.04563^{* *}$ & $\begin{array}{l}0.01 \\
9\end{array}$ \\
\hline \multicolumn{5}{|l|}{ Interactions } \\
\hline PES * Social Agroforestry network & $\overline{0}-00467^{* \star *}$ & $\begin{array}{l}0.00 \\
1\end{array}$ & $0.00968^{* * *}$ & $\begin{array}{l}0.00 \\
2\end{array}$ \\
\hline PES * Social Oil palm network & -0.00062 & $\begin{array}{l}0.00 \\
1\end{array}$ & -0.00017 & $\begin{array}{l}0.00 \\
0\end{array}$ \\
\hline $\begin{array}{l}\text { PES* Compliance with the social norm (Normative social } \\
\text { influence) }\end{array}$ & 0.00252 & $\begin{array}{l}0.00 \\
2\end{array}$ & -0.00120 & $\begin{array}{l}0.00 \\
2\end{array}$ \\
\hline PES *Environmental perception of the network & $0.00186^{* *}$ & $\begin{array}{l}0.00 \\
1\end{array}$ & -0.00017 & $\begin{array}{l}0.00 \\
1\end{array}$ \\
\hline Constant & $0.52212^{* *}$ & $\begin{array}{l}0.23 \\
5 \\
\end{array}$ & 0.54140 & $\begin{array}{l}0.42 \\
9\end{array}$ \\
\hline
\end{tabular}

Note: All models control for age, sex, education, land tenure, family members, people known by name and people with whom the participant speak in the last month in the same session. Standard errors are clustered at the session level. ${ }^{*} p<0.1,{ }^{* *} p<0.05,{ }^{* * *} p<0.01$

Considering that economic incentives for conservation influence moral motivations for conservation through their interaction with social preferences (Liu et al. 2014). We consider the interaction of the PES incentive with the social network characteristics. We find that in the collective scheme once the incentive is offered having a network that cultivate agroforestry positively influences conservation behavior and slightly increases land allocated to agroforestry by 0.9 percentual points; this effect is inverse under the individual incentive where the land allocated to conservation is reduced in 0.4 percentual points.

Individual environmental perception plays an important role under the individual scheme increasing the land allocated to conservation by $10 \%$, under the collective scheme there is not effect. Once the incentive is offered, we observe a small positive and significant effect of environmental connectedness of the network under the individual scheme, meaning that when deciding to cultivate rubber agroforestry due to the positive environmental externalities, the 
participant's land investment decision takes into consideration that his network is conscious about the environment.

\section{Conclusions}

Payment for Environmental Services is an instrument that provides incentives for conservation. We analyze the effectiveness of individual and collective incentives and find that both types of schemes are effective at increasing conservation, though the impact is relatively small. A one percent increase in PES increases conservation in only 2 percentual points or three percent of the investment.

Our findings contribute to the discussion in terms of individual versus collective PES schemes, specifically showing that collective schemes can be as effective as individual schemes.. The results indicate that collective schemes can be more cost-effective because it achieves conservation outcome at lower incentive payments and engage large landowners, who may feel the moral pressure to contribute their share under such institutional arrangements. While smaller farmers respond to individual and collective incentives, their contribution is slightly larger under the individual scheme (0.3\%) compared to the collective scheme $(0.1 \%)$. In areas where transaction costs are not so high and the prevalence is small patches from small farmers, individual schemes could achieve higher conservation outcomes; while in critical areas with large farmers collective schemes might be more suitable.

It should be kept in mind, however, that the effectiveness of PES is highly place-specific and depends on the social norms prevalent in the communities. The analysis of the social network characteristics and its interaction with PES incentives highlights the fact that the adequacy and efficiency of a specific scheme partly depends on the social norms and network characteristics of the area. In contexts where farmers are highly committed to what his close network does as a whole, such as the case of our study area where the social norm is the cultivation of oil palm, higher monetary incentives are required to compensate the opportunity costs forgone for a crop such as oil palm.

The positive and significant effect of the social agroforestry network opens a door of opportunities and strategies to promote pro-conservation behavior. Acknowledging that financial resources are not always available to fully compensate farmers for not cultivating oil palm, strategies based on the social context could complement the monetary incentives, promoting good reputation, engaging with productive associations to encourage their 58 
members to become more environmentally friendly can stimulate change in behavior. This understanding is important in order to provide policymakers with key aspects when designing PES, especially the messaging that monetary incentives are not a single solution for such a complex problem, and that a holistic approach in defining strategies that contemplates not only monetary aspects but also key features from the close social network of the farmer can achieve a higher impact.

This study highlights how endowment heterogeneity and social network can affect the success of PES schemes. Further research could analyze higher levels of PES under both schemes, providing insights into the discussion of appropriateness of monetary incentives aiming at reducing cultivation of high profitable crops. In addition, analysis comparing monetary vs social incentives and the long-term effect could provide insights on which strategies are more efficient, considering limited resources to finance monetary incentives.

Acknowledgement: The authors gratefully acknowledge funding provided by the German Research Foundation (DFG) through the CRC 990 "Ecological and Socioeconomic Functions of Tropical Lowland Rainforest Transformation Systems (Sumatra, Indonesia)". 


\section{Chapter 4. Concluding remarks}

In this dissertation we show that social capital plays an important role in adoption of sustainable practices in the agricultural sector. In one hand, we provide empirical evidence about the significant and positive influence of social capital variables on the level of perceived control and intention to perform adoption of pressurized irrigation. In the other, we show that social capital, in the form of network, could negatively influence conservation behavior when the social norm is to cultivate the more profitable crop as in the case of oil palm in Indonesia.

\section{Main findings}

Social capital is a key concept to unveil complex decision-making processes nonetheless, when we combined social capital with TPB we observed significant effects of social capital on cognitive elements that otherwise would not have been possible to measure.

We applied the concept of social capital jointly with the Theory of Planned Behavior (TPB) to identify factors that influence adoption of pressurized irrigation. We provide evidence that TPB is a framework to identify beliefs that are affecting attitudes, subjective norms and perceived control, which consequently affect decisions through intentions. The literature often uses social capital to explain behavior directly. Here, we explore different pathways through which social capital may affect adoption and find that key elements such as networks and trust, influence adoption indirectly through the TPB construct. Although there is not a direct effect on adoption, they are important because they influence significantly psychological cognitive constructs that affect intention and actual behavior. For instance, network has a strong influence on perceived control. The farmer is more confident in performing the behavior the larger his network that has already implemented the technology. Therefore, social capital is relevant because it allows farmers to exchange and ask for help in case of need. 
Similarly, we find that socio-demographic variables are not directly related to decisions of adoption but have an indirect effect through intention. Extension services had not significant effect on adoption, but its effects are large on perceived control.

A key finding in the context of Chile is that attitudes are high and positive towards the technology, but it did not show a significant effect on intention. Therefore, investment should target networks and water organizations that help to establish the social norms and can create this informal rule of implementing sustainable practices.

Now, when analyzing social capital in a context of PES schemes in Indonesia. We find that individuals were more susceptible to social capital variables under collective schemes than in the individual scheme. Social capital in the form of network shows a negative and significant influence of the share of land allocated to rubber agroforestry, while membership and environmental awareness of the network have a positive influence. In the individual scheme were more relevant individual characteristics such as individual environmental perception, land tenure and if the participant cultivates rubber agroforestry.

The effect of social network, when comparing both case studies reaffirms the need to design strategies that are context specific and that consider the social dynamics of each site. PES schemes are external formal institutions that need to take into consideration the informal rules of the community and the characteristics of the network in order to achieve the desire outcomes. Network is relevant because it strengthens and rule out the social norms in the community, the farmer gives weight to what the network expect him to do. Nonetheless, when analyzing specifically adoption of a technology, network becomes more important as a window of support, flow of information, and access to financing that makes the process of adoption easier.

Another key finding is that collective schemes can be as effective as individual schemes, as we observed a positive and significant increase on conservation outcomes. Collective schemes can be more cost-effective because it achieves same conservation outcome at lower incentive payments. Contrary to the findings in previous experiments, collective schemes do not undermine intrinsic motivations for conservation. 
In addition, the results show that land heterogeneity matters, collective schemes may be especially suitable to engage large landowners, who may feel the moral pressure to contribute their share under such institutional arrangements. While smaller farmers respond to individual and collective incentives. It should be kept in mind, however, that the effectiveness of PES is highly place-specific and depends on the social norms prevalent in the communities.

\section{Policy implications}

Our empirical results have important policy implications. In the case study from Chile, we identified that attitude campaigns are not enough to influence intentions. The government could target and change the norm of superficial irrigation by convincing people of core beliefs associated with water conservation awareness and to boost farmer's trust in water organizations that could foster cooperation to adopt pressurized irrigation systems as a norm. In addition, extension services should focus on generating exchange of knowledge through social networks to facilitate action and increase farmers' perceived self-confidence about performing the change from superficial to pressurized irrigation; in this context this is more important than improving attitudes towards the technology.

In the case study in Indonesia with regards to Payment for Environmental Services, our findings have important implications for REDD focus countries, which is the most important arena for collective PES nowadays. Policy makers can build up on existing social norms; provide economic incentives for conservation and complement informal institutions. Future PES should focus and be tailor to the characteristics of the participants in terms of endowment and should have a better understanding of the social norms of the context.

\section{Limitations and ideas for further research}

There are some factors that limit the scope of the study. In this section I highlight the major limitations and provide ideas for further research.

First, in Chapter 2 we estimate an integral model that considers the effects of social capital, psychological factors, and control variables to explain adoption of pressurized irrigation. This analysis can further benefit by considering time and risk preferences of the farmers, so the explanatory power of the model can be increase. Further research could consider how risk preferences interact with psychological factors and if the interaction with trust, network, and their intention of adoption. 
With regards to model specification, the model provided robust results, but additional interaction of variables could not be performed, as the analysis of covariance required a higher sample size. We believe that for further research, the results can be defined as a baseline to follow-up adoption rates and identify whether government interventions had any impact on beliefs, intentions and adoption expanding the database for analysis.

In Chapter 3, there were no significant differences between treatments having both a positive influence on conservation behavior. We identify that in the collective treatment, the preestablished threshold could have been set higher. In addition, as PES requires certain level of organizational structure, further experiments could include the interaction with current social capital (trust) and assess whether the introduction of incentives fosters collective action. In the same line, further research could be beneficial on understanding higher payment levels, and the interaction with already establish collective action mechanism. Future work should measure expectations on others behavior and try to capture expected probability of receiving a payment under the collective incentive. 


\section{References}

Adhikari, B., Agrawal, A., 2013. Understanding the social and ecological outcomes of PES projects: A review and an analysis. Conserv. Soc. 11, 359. https://doi.org/10.4103/0972-4923.125748

Ajzen, I., 2015. The theory of planned behaviour is alive and well, and not ready to retire: a commentary on Sniehotta, Presseau, and Araújo-Soares. Health Psychol. Rev. 9, 131-137. https://doi.org/10.1080/17437199.2014.883474

Ajzen, I., 2011. Attitudes, personality and behavior, 2. ed., reprint. ed, Mapping social psychology. Open Univ. Press, Maidenhead.

Ajzen, I., 2003. Theory of Planned Behavior. Soc. Psychol. I Soc. Cogn. Soc. Percept. 347377.

Ajzen, I., 2002. Perceived Behavioral Control, Self-Efficacy, Locus of Control, and the Theory of Planned Behavior.

Ajzen, I., 1991. Theory of Planned Behavior. Organ. Behav. Hum. Decis. Process. 179-211.

Ajzen, I., 1985. From intentions to actions: A theory of planned behavior, in: Action Control. Springer, pp. 11-39.

Ajzen, I., Fishbein, M., 2005. The influence of attitudes on behavior. Handb. Attitudes 173, 221.

Alexandratos, N., Bruinsma, J., others, 2012. World agriculture towards 2030/2050: the 2012 revision. ESA Working paper Rome, FAO.

AQUASTAT, 2014. Area Equipped for Irrigation.

Barbier, E.B., 2004. Explaining agricultural land expansion and deforestation in developing countries. Am. J. Agric. Econ. 86, 1347-1353.

Barr, R., Di Falco, S., Mourato, S., 2011. Income diversification, social capital and their potential role in uptake of marine Payments for Environmental Services schemes: a study from a Tanzanian fishing community. Grantham Res. Inst. Clim. Change Environ.

Battikhi, A.M., Abu-Hammad, A.H., 1994. Comparison between the efficiencies of surface and pressurized irrigation systems in Jordan. Irrig. Drain. Syst. 8, 109-121. https://doi.org/10.1007/BF00881179 
Baumgart-Getz, A., Prokopy, L.S., Floress, K., 2012. Why farmers adopt best management practice in the United States: A meta-analysis of the adoption literature. J. Environ. Manage. 96, 17-25.

Bhatti, T., 1970. Exploring Factors Influencing the Adoption of Mobile Commerce. J. Internet Bank. Commer. 12, 1-13.

Borges, J.A.R., Lansink, A.G.J.M.O., Ribeiro, C.M., Lutke, V., 2014. Understanding farmers' intention to adopt improved natural grassland using the theory of planned behavior. Livest. Sci. 169, 163-174. https://doi.org/10.1016/j.livsci.2014.09.014

Bullock, D.G., 1992. Crop rotation. Crit. Rev. Plant Sci. 11, 309-326.

Burton, R.J.F., 2014. The influence of farmer demographic characteristics on environmental behaviour: A review. J. Environ. Manage. 135, 19-26. https://doi.org/10.1016/j.jenvman.2013.12.005

Cacho, O.J., Milne, S., Gonzalez, R., Tacconi, L., 2014. Benefits and costs of deforestation by smallholders: Implications for forest conservation and climate policy. Ecol. Econ. 107, 321-332. https://doi.org/10.1016/j.ecolecon.2014.09.012

Carmeli, A., Spreitzer, G.M., 2009. Trust, connectivity, and thriving: Implications for innovative behaviors at work. J. Creat. Behav. 43, 169-191.

Chen, H., Wang, J., Huang, J., 2014. Policy support, social capital, and farmers' adaptation to drought in China. Glob. Environ. Change 24, 193-202. https://doi.org/10.1016/j.gloenvcha.2013.11.010

Chin, H.-C., Choong, W.-W., Alwi, S.R.W., Mohammed, A.H., 2016. Using Theory of Planned Behaviour to explore oil palm smallholder planters' intention to supply oil palm residues. J. Clean. Prod. 126, 428-439. https://doi.org/10.1016/j.jclepro.2016.03.042

Clements, T., John, A., Nielsen, K., An, D., Tan, S., Milner-Gulland, E.J., 2010. Payments for biodiversity conservation in the context of weak institutions: Comparison of three programs from Cambodia. Ecol. Econ. 69, 1283-1291. https://doi.org/10.1016/j.ecolecon.2009.11.010

CNR, C.N. de R., 2020. Resolucion exenta - Aprueba bases correspondientes al Programa Especial Pequeña Agricultura $N^{\circ}$ 202-2020, en virtud del artículo 3 inciso 3 de la Ley $\mathrm{N}^{\circ} 18.450$.

Coleman, J.S., 1988. Social Capital in the Creation of Human Capital. Am. J. Sociol. 94, S95S120.

Coleman, J.S., 1987. Norms as social capital. Econ. Imp. 133-155. 
Conner, M., Armitage, C.J., 1998. Extending the theory of planned behavior: A review and avenues for further research. J. Appl. Soc. Psychol. 28, 1429-1464.

Czap, H.J., Czap, N.V., Lynne, G.D., Burbach, M.E., 2016. Farm Bill 2014: An Experimental Investigation of Conservation Compliance. J. Sustain. Dev. 9, 23. https://doi.org/10.5539/jsd.v9n3p23

Darouich, H.M., Pedras, C.M.G., Gonçalves, J.M., Pereira, L.S., 2014. Drip vs. surface irrigation: A comparison focussing on water saving and economic returns using multicriteria analysis applied to cotton. Biosyst. Eng. 122, 74-90. https://doi.org/10.1016/j.biosystemseng.2014.03.010

De Fraiture, C., Perry, C., 2007. Why is agricultural water demand unresponsive at low price ranges. Irrig. Water Pricing Gap Theory Pract. 94-107.

De Leeuw, A., Valois, P., Ajzen, I., Schmidt, P., 2015. Using the theory of planned behavior to identify key beliefs underlying pro-environmental behavior in high-school students: Implications for educational interventions. J. Environ. Psychol. 42, 128-138.

Devlieger, I., Rosseel, Y., 2017. Factor Score Path Analysis. Methodology 13, 31-38. https://doi.org/10.1027/1614-2241/a000130

Di Falco, S., Feri, F., Pin, P., Vollenweider, X., 2011. Avoiding the Network Tax: Social Pressure and Labour Sharing in Village Economies.

Dickman, A.J., Macdonald, E.A., Macdonald, D.W., 2011. A review of financial instruments to pay for predator conservation and encourage human-carnivore coexistence. Proc. Natl. Acad. Sci. U. S. A. 108, 13937-13944. https://doi.org/10.1073/pnas.1012972108

Diederen, P., Van Meijl, H., Wolters, A., Bijak, K., 2003. Innovation adoption in agriculture: innovators, early adopters and laggards. Cah. Econ. Sociol. Rural. 67, 29-50.

Dillon, Harbrinderjit Singh, Laan, T., Dillon, Harya Setyaka, International Institute for Sustainable Development, Global Subsidies Initiative, International Institute for Sustainable Development, 2008. Biofuels, at what cost? government support for ethanol and biodiesel in Indonesia. International Institute for Sustainable Development, Winnipeg, Man.

Djanibekov, U., Villamor, G.B., 2017. Market-based instruments for risk-averse farmers: rubber agroforest conservation in Jambi Province, Indonesia. Environ. Dev. Econ. 22, 133-155. https://doi.org/10.1017/S1355770X16000310

Donoso, G., 2015. Chilean Water Rights Markets as a Water Allocation Mechanism, in: Use of Economic Instruments in Water Policy. Springer, pp. 265-278. 
Dowd, A., Marshall, N., Fleming, A., Jakku, E., Gaillard, E., Howden, S., 2014. The role of networks in transforming Australian agriculture. https://doi.org/10.1038/NCLIMATE2275

Durlauf, S.N., 2002. On the Empirics of Social Capital. Source Econ. J. Featur. 112, 459-479.

Easter, K.W., Huang, Q. (Eds.), 2014. Water Markets for the 21st Century, Global Issues in Water Policy. Springer Netherlands, Dordrecht. https://doi.org/10.1007/978-94-0179081-9

Edwards-Jones, G., 2006. Modelling farmer decision-making: concepts, progress and challenges. Anim. Sci. 82, 783-790. https://doi.org/10.1017/ASC2006112

Ekadinata, A., Widayati, A., Vincent, G., 2004. Rubber agroforest identification using objectbased classification in Bungo District, Jambi, Indonesia, in: 25th Asian Conference on Remote Sensing, Chiang Mai, Thailand. pp. 22-26.

Eloy, L., Méral, P., Ludewigs, T., Pinheiro, G.T., Singer, B., 2012. Payments for ecosystem services in Amazonia. The challenge of land use heterogeneity in agricultural frontiers near Cruzeiro do Sul (Acre,Brazil). J. Environ. Plan. Manag. 55, 685-703. https://doi.org/10.1080/09640568.2011.621021

Elster, J., 1989. Wage Bargaining and Social Norms. Acta Sociol. 32, 113-136.

Engler, A., Jara-Rojas, R., Bopp, C., 2016. Efficient use of Water Resources in Vineyards: A Recursive joint Estimation for the Adoption of Irrigation Technology and Scheduling. Water Resour. Manag. 30, 5369-5383. https://doi.org/10.1007/s11269-016-1493-5

Ervin, C.A., Ervin, D.E., 1982. Factors affecting the use of soil conservation practices: hypotheses, evidence, and policy implications. Land Econ. 58, 277-292.

Esterhuyse, P., 2012. Social Capital in a Rainwater-Harvesting Project in Rural South Africa. Irrig. Drain. 61, 95-105. https://doi.org/10.1002/ird.1690

Euler, M., Schwarze, S., Siregar, H., Qaim, M., n.d. GOEDOC-Dokumenten-und Publikationsserver der Georg-August-Universität Göttingen.

FAO, 2011. Save and Grow A policymaker's guide to the sustainable intensification of smallholder crop production.

Fazio, R., Farm, S., Rodriguez, J., Molnar, J., 2017. Barriers to the Adoption of Sustainable Agricultural Practices: Working Farmer and Change Agent Perspectives.

Feder, G., Just, R.E., Zilberman, D., 1985. Adoption of Agricultural Innovations in Developing Countries: A Survey. Econ. Dev. Cult. Change 33, 255-298. 
Ferraro, P.J., Price, M.K., 2013. Using Nonpecuniary Strategies to Influence Behavior: Evidence from a Large-Scale Field Experiment. Rev. Econ. Stat. 95, 64-73. https://doi.org/10.1162/REST_a_00344

Fishbein, M., Ajzen, I., 2011. Predicting and Changing Behavior: The Reasoned Action Approach. Psychology Press, Taylor \& Francis Group, New York, NY.

Fitzherbert, E.B., Struebig, M.J., Morel, A., Danielsen, F., Brühl, C.A., Donald, P.F., Phalan, B., 2008. How will oil palm expansion affect biodiversity? Trends Ecol. Evol. 23, 538545. https://doi.org/10.1016/j.tree.2008.06.012

Foster, A.D., Rosenzweig, M.R., 2010. Microeconomics of Technology Adoption. Annu. Rev. Econ. 2, 395-424. https://doi.org/10.1146/annurev.economics.102308.124433

Garreaud, R.D., Boisier, J.P., Rondanelli, R., Montecinos, A., Sepúlveda, H.H., Veloso-Aguila, D., 2020. The Central Chile Mega Drought (2010-2018): A climate dynamics perspective. Int. J. Climatol. 40, 421-439. https://doi.org/10.1002/joc.6219

Gasson, R., 1973. Goals and Values of Farmers. J. Agric. Econ. 24, 521-542. https://doi.org/10.1111/j.1477-9552.1973.tb00952.x

Genius, M., Koundouri, P., Nauges, C., Tzouvelekas, V., 2014. Information Transmission in Irrigation Technology Adoption and Diffusion: Social Learning, Extension Services, and Spatial Effects. Am. J. Agric. Econ. 96, 328-344. https://doi.org/10.1093/ajae/aat054

Glanz, K., Rimer, B.K., Viswanath, K. (Eds.), 2008. Health behavior and health education: theory, research, and practice, 4th ed. ed. Jossey-Bass, San Francisco, CA.

Godfray, H.C.J., Beddington, J.R., Crute, I.R., Haddad, L., Lawrence, D., Muir, J.F., Pretty, J., Robinson, S., Thomas, S.M., Toulmin, C., 2010. Food Security: The Challenge of Feeding 9 Billion People. Science 327, 812-818. https://doi.org/10.1126/science.1185383

Granja, C.R., Wollni, M., 2018. Opportunistic Behaviour and Trust: Experimental Results from Broccoli Farmers in Ecuador. J. Agric. Econ. https://doi.org/10.1111/1477-9552.12271

Grima, N., Singh, S.J., Smetschka, B., Ringhofer, L., 2016. Payment for Ecosystem Services (PES) in Latin America: Analysing the performance of 40 case studies. Ecosyst. Serv. 17, 24-32. https://doi.org/10.1016/j.ecoser.2015.11.010

Grootaert, C., 2003. Measuring social capital: An integrated questionnaire. World Bank Publications.

Grootaert, C., 1999. Social capital, household welfare, and poverty in Indonesia. World Bank Policy Research Working Paper No. 2148. 
Hamilton, S.K., Doll, J.E., Robertson, G.P., 2015. The Ecology of Agricultural Landscapes: Long-Term Research on the Path to Sustainability. Oxford University Press.

Handberg, Ø.N., Angelsen, A., 2016. Pay little, get little; pay more, get a little more: A framed forest in Tanzania. Ecol. Econ. https://doi.org/10.1016/j.ecolecon.2016.09.025

Handschuch, C., Wollni, M., 2016. Improved production systems for traditional food crops: the case of finger millet in western Kenya. Food Secur. 8, 783-797. https://doi.org/10.1007/s12571-016-0577-7

Hansson, H., Ferguson, R., Olofsson, C., 2012. Psychological Constructs Underlying Farmers' Decisions to Diversify or Specialise their Businesses - An Application of Theory of Planned Behaviour. J. Agric. Econ. 63, 465-482. https://doi.org/10.1111/j.14779552.2012.00344.x

Harrison, P. (Ed.), 2002. World agriculture: towards 2015/2030: summary report. Food and Agriculture Organization of the United Nations, Rome.

Hawkins, C.V., 2007. Local Government Joint Ventures: Cooperation and Competition for Economic Development. ProQuest.

Hearne, R., Donoso, G., 2014a. Water markets in Chile: Are they meeting needs?, in: Water Markets for the 21st Century. Springer, pp. 103-126.

Hearne, R., Donoso, G., 2014b. Water markets in Chile: Are they meeting needs?, in: Water Markets for the 21st Century. Springer, pp. 103-126.

Hearne, R.R., Easter, K.W., 1997. The economic and financial gains from water markets in Chile. Agric. Econ. 15, 187-199.

Hogg, M.A., Terry, D.J., 2000. Social contextual influences on attitude-behaviour correspondence, attitude change, and persusion., in: Attitudes, Behaviour, and Social Context. Lawrence Erlbaum, Mahwah NJ, p. 9.

Hu, L., Bentler, P.M., 1999. Cutoff criteria for fit indexes in covariance structure analysis: Conventional criteria versus new alternatives. Struct. Equ. Model. Multidiscip. J. 6, 155. https://doi.org/10.1080/10705519909540118

Hunecke, C., Engler, A., Jara-Rojas, R., Poortvliet, P.M., 2017. Understanding the role of social capital in adoption decisions: An application to irrigation technology. Agric. Syst. 153, 221-231. https://doi.org/10.1016/j.agsy.2017.02.002

Ingram, G.K., Hong, Y., 2011. Climate change and land policies. Lincoln Institute of Land Policy, Cambridge, Mass. 
Islam, M.K., Merlo, J., Kawachi, I., Lindström, M., Gerdtham, U.-G., 2006. Social capital and health: Does egalitarianism matter? A literature review. Int. J. Equity Health 5, 3. https://doi.org/10.1186/1475-9276-5-3

Jacques, D.C., Marinho, E., d'Andrimont, R., Waldner, F., Radoux, J., Gaspart, F., Defourny, P., 2018. Social capital and transaction costs in millet markets. Heliyon 4, e00505. https://doi.org/10.1016/j.heliyon.2018.e00505

Jara-Rojas, R., Bravo-Ureta, B.E., Díaz, J., 2012a. Adoption of water conservation practices: A socioeconomic analysis of small-scale farmers in Central Chile. Agric. Syst. 110, 5462. https://doi.org/10.1016/j.agsy.2012.03.008

Jara-Rojas, R., Bravo-Ureta, B.E., Díaz, J., 2012b. Adoption of water conservation practices: A socioeconomic analysis of small-scale farmers in Central Chile. Agric. Syst. https://doi.org/10.1016/j.agsy.2012.03.008

Jayachandran, S., de Laat, J., Lambin, E.F., Stanton, C.Y., Audy, R., Thomas, N.E., 2017. Cash for carbon: A randomized trial of payments for ecosystem services to reduce deforestation. Science 357, 267. https://doi.org/10.1126/science.aan0568

Jones, K., 1996. Trust as an Affective Attitude. Ethics 107, 4-25. https://doi.org/10.1086/233694

Jordán, C., Speelman, S., 2020. On-farm adoption of irrigation technologies in two irrigated valleys in Central Chile: The effect of relative abundance of water resources. Agric. Water Manag. 236, 106147. https://doi.org/10.1016/j.agwat.2020.106147

Jordan, R., 2015. Agriculture and Deforestation: How to Reduce Impacts [WWW Document]. Stanf. Woods Inst. Environ. URL https://woods.stanford.edu/newsevents/news/agriculture-and-deforestation-how-reduce-impacts (accessed 9.27.17).

Kerr, J.M., Vardhan, M., Jindal, R., 2014. Incentives, conditionality and collective action in payment for environmental services. Int. J. Commons 8, 595-616.

Keser, C., Markstädter, A., Schmidt, M., Schnitzler, C., 2014. Social Costs of InequalityHeterogeneous Endowments in Public-Good Experiments.

Khalil, E.L. (Ed.), 2003. Trust. Edward Elgar Pub, Cheltenham.

Kline, R.B., 2015. Principles and practice of structural equation modeling. Guilford publications.

Kline, R.B., 2012. Assumptions in structural equation modeling., in: Handbook of Structural Equation Modeling. 
Klöckner, C.A., 2013a. A comprehensive model of the psychology of environmental behaviour-A meta-analysis. Glob. Environ. Change 23, 1028-1038. https://doi.org/10.1016/j.gloenvcha.2013.05.014

Klöckner, C.A., 2013b. A comprehensive model of the psychology of environmental behaviour-A meta-analysis. Glob. Environ. Change 23, 1028-1038. https://doi.org/10.1016/j.gloenvcha.2013.05.014

Koh, L.P., Wilcove, D.S., 2008. Is oil palm agriculture really destroying tropical biodiversity? Conserv. Lett. 1, 60-64. https://doi.org/10.1111/j.1755-263X.2008.00011.x

Kollmuss, A., Agyeman, J., 2002. Mind the Gap: Why do people act environmentally and what are the barriers to pro-environmental behavior? Environ. Educ. Res. 8, 239-260. https://doi.org/10.1080/13504620220145401

Lanza Castillo, G.M., Engler, A., Wollni, M., 2021. Planned behavior and social capital: Understanding farmers' behavior toward pressurized irrigation technologies. Agric. Water Manag. 243, 106524. https://doi.org/10.1016/j.agwat.2020.106524

Lapeyre, R., Pirard, R., Leimona, B., 2015. Payments for environmental services in Indonesia: What if economic signals were lost in translation? Land Use Policy 283-291.

Läpple, D., Kelley, H., 2013. Understanding the uptake of organic farming: Accounting for heterogeneities among Irish farmers. Ecol. Econ., Transaction Costs and Environmental Policy 88, 11-19. https://doi.org/10.1016/j.ecolecon.2012.12.025

Le Mouël, C., Forslund, A., 2017. How can we feed the world in 2050? A review of the responses from global scenario studies. Eur. Rev. Agric. Econ. 44, 541-591. https://doi.org/10.1093/erae/jbx006

Le Velly, G., Dutilly, C., 2016. Evaluating Payments for Environmental Services: $\begin{array}{llll}\text { Methodological } & \text { Challenges. } & \text { PLoS }\end{array}$ https://doi.org/10.1371/journal.pone.0149374

Lecouteux, G., 2013. Reconciling behavioural and neoclassical economics.

Lee, D.R., 2005. Agricultural Sustainability and Technology Adoption: Issues and Policies for Developing Countries. Am. J. Agric. Econ. 87, 1325-1334. https://doi.org/10.1111/j.1467-8276.2005.00826.x

Letey, J., Dinar, A., Woodring, C., Oster, J.D., 1990. An economic analysis of irrigation systems. Irrig. Sci. 11, 37-43.

Li, C.-H., 2014a. The performance of MLR, USLMV, and WLSMV estimation in structural regression models with ordinal variables. Michigan State University. 
Li, C.-H., 2014b. The performance of MLR, USLMV, and WLSMV estimation in structural regression models with ordinal variables. Michigan State University.

List, J.A., 2008. Introduction to field experiments in economics with applications to the economics of charity. Exp. Econ. 11, 203-212. https://doi.org/10.1007/s10683-0089201-9

Liu, J., Qu, H., Huang, D., Chen, G., Yue, X., Zhao, X., Liang, Z., 2014. The role of social capital in encouraging residents' pro-environmental behaviors in community-based ecotourism. Tour. Manag. 41, 190-201. https://doi.org/10.1016/j.tourman.2013.08.016

Lorenz, E., 2000. Neither Friends nor Strangers: Informal Networks of Subcontracting in French Industry.

Lozano Parra, J., Pulido Fernández, M., Garrido Velarde, J., 2020. The Availability of Water in Chile: A Regional View from a Geographical Perspective, in: Resources of Water [Working Title]. IntechOpen. https://doi.org/10.5772/intechopen.92169

Lynne, G.D., Franklin Casey, C., Hodges, A., Rahmani, M., 1995. Conservation technology adoption decisions and the theory of planned behavior. J. Econ. Psychol. 16, 581-598. https://doi.org/10.1016/0167-4870(95)00031-6

Lyon, F., 2000. Trust, Networks and Norms: The Creation of Social Capital in Agricultural Economies in Ghana. World Dev. 28, 663-681. https://doi.org/10.1016/S0305750X(99)00146-1

Maertens, A., Barrett, C.B., 2013. Measuring Social Networks' Effects on Agricultural Technology Adoption. Am. J. Agric. Econ. 95, 353-359. https://doi.org/10.1093/ajae/aas049

McPhee, J., de la Fuente, A., Herrera, P., Niño, Y., Olivares, M., Sancha, A.M., Tamburrino, A., Vargas, X., Red Interamericana de Academias de Ciencias (México), Foro Consultivo Científico y Tecnológico, A. (México), 2012. El sector del agua en Chile. Su estado y sus retos, in: Diagnóstico del agua en las Américas. IANAS : Foro Consultivo Científico y Tecnológico, México.

Meijer, S.S., Catacutan, D., Sileshi, G.W., Nieuwenhuis, M., 2015. Tree planting by smallholder farmers in Malawi: Using the theory of planned behaviour to examine the relationship between attitudes and behaviour. J. Environ. Psychol. 43, 1-12. https://doi.org/10.1016/j.jenvp.2015.05.008

Midler, E., Pascual, U., Drucker, A.G., Narloch, U., Soto, J.L., 2015. Unraveling the effects of payments for ecosystem services on motivations for collective action. Ecol. Econ. 120, 394-405. https://doi.org/10.1016/j.ecolecon.2015.04.006 
Mobley, C., Vagias, W.M., DeWard, S.L., 2010. Exploring Additional Determinants of Environmentally Responsible Behavior: The Influence of Environmental Literature and Environmental Attitudes. Environ. Behav. 42, 420-447. https://doi.org/10.1177/0013916508325002

Motoshita, M., Ono, Y., Pfister, S., Boulay, A.-M., Berger, M., Nansai, K., Tahara, K., Itsubo, N., Inaba, A., 2018. Consistent characterisation factors at midpoint and endpoint relevant to agricultural water scarcity arising from freshwater consumption. Int. J. Life Cycle Assess. 23, 2276-2287. https://doi.org/10.1007/s11367-014-0811-5

Muradian, R., Corbera, E., Pascual, U., Kosoy, N., May, P.H., 2010a. Reconciling theory and practice: An alternative conceptual framework for understanding payments for environmental services. Ecol. Econ., Special Section - Payments for Environmental Services: Reconciling Theory and Practice 69, 1202-1208. https://doi.org/10.1016/j.ecolecon.2009.11.006

Muradian, R., Corbera, E., Pascual, U., Kosoy, N., May, P.H., 2010b. Reconciling theory and practice: An alternative conceptual framework for understanding payments for environmental services. Ecol. Econ., Special Section - Payments for Environmental Services: Reconciling Theory and Practice 69, 1202-1208. https://doi.org/10.1016/j.ecolecon.2009.11.006

Muthén, L.K., Muthén, B., 2009. Regression Analysis, Exploratory Factor Analysis, Confirmatory Factor Analysis, And Structural Equation Modeling For Categorical, Censored, And Count Outcomes.

Muthén, L.K., Muthén, B.O., 2010. Mplus User's Guide: Statistical Analysis with Latent Variables: User's Guide. Muthén \& Muthén.

Nair, K.P., 2019. How to Manage Water Use for Sustainable Agriculture?, in: Nair, K.P. (Ed.), Intelligent Soil Management for Sustainable Agriculture: The Nutrient Buffer Power Concept. Springer International Publishing, Cham, pp. 191-232. https://doi.org/10.1007/978-3-030-15530-8_18

Narloch, U., Pascual, U., Drucker, A.G., 2012. Collective Action Dynamics under External Rewards: Experimental Insights from Andean Farming Communities. World Dev. 40, 2096-2107. https://doi.org/10.1016/j.worlddev.2012.03.014

Nations, F. and A.O. of the U., 1995. Dimensions of Need: An Atlas of Food and Agriculture. Food \& Agriculture Org. 
Niles, M.T., Brown, M., Dynes, R., 2016. Farmer's intended and actual adoption of climate change mitigation and adaptation strategies. Clim. Change 135, 277-295. https://doi.org/10.1007/s10584-015-1558-0

Nuthall, P.L., 2001. Managerial ability - a review of its basis and potential improvement using psychological concepts. Agric. Econ. 24, 247-262. https://doi.org/10.1016/S01695150(00)00069-4

ODEPA, O. de E. y P.A., 2017. Panorama de la Agricultura Chilena . Chilean Agriculture Overview 2017. Santiago, Chile.

ODEPA, O. de E. y P.A., 2013. Panorama de la Agricultura chilena. Santiago Chile.

Ostrom, E., 2007. The Meaning of Social Capital and Its Link to Collective Action (SSRN Scholarly Paper No. ID 1304823). Social Science Research Network, Rochester, NY.

Ostrom, E., Ahn, T.K., 2003. Foundations of Social Capital (Books). Edward Elgar Publishing.

Pagiola, S., Arcenas, A., Platais, G., 2005. Can Payments for Environmental Services Help Reduce Poverty? An Exploration of the Issues and the Evidence to Date from Latin America. World Dev., Institutional arrangements for rural poverty reduction and resource conservation 33, 237-253. https://doi.org/10.1016/j.worlddev.2004.07.011

Pagiola, S., Ramírez, E., Gobbi, J., de Haan, C., Ibrahim, M., Murgueitio, E., Ruíz, J.P., 2007. Paying for the environmental services of silvopastoral practices in Nicaragua. Ecol. Econ. 64, 374-385. https://doi.org/10.1016/j.ecolecon.2007.04.014

Pannell, D.J., Marshall, G.R., Barr, N., Curtis, A., Vanclay, F., Wilkinson, R., 2006. Understanding and promoting adoption of conservation practices by rural landholders. Aust. J. Exp. Agric. 46, 1407-1424.

Pascual, U., Perrings, C., 2007. Developing incentives and economic mechanisms for in situ biodiversity conservation in agricultural landscapes. Agric. Ecosyst. Environ. 121, 256-268. https://doi.org/10.1016/j.agee.2006.12.025

Pastor, A.V., Palazzo, A., Havlik, P., Biemans, H., Wada, Y., Obersteiner, M., Kabat, P., Ludwig, F., 2019. The global nexus of food-trade-water sustaining environmental flows by 2050. Nat. Sustain. 2, 499-507. https://doi.org/10.1038/s41893-019-0287-1

Paul, C.J., Weinthal, E.S., Bellemare, M.F., Jeuland, M.A., 2016. Social capital, trust, and adaptation to climate change: Evidence from rural Ethiopia. Glob. Environ. Change 36, 124-138. https://doi.org/10.1016/j.gloenvcha.2015.12.003

Pelling, M., High, C., 2005. Social learning and adaptation to climate change. Benfield Hazard Res. Cent. Disaster Stud. Work. Pap. 11, 1-19. 
Playán, E., Mateos, L., 2006. Modernization and optimization of irrigation systems to increase water productivity. Agric. Water Manag. 80, 100-116.

Poiani, K.A., Richter, B.D., Anderson, M.G., Richter, H.E., 2000. Biodiversity Conservation at Multiple Scales: Functional Sites, Landscapes, and Networks. BioScience 50, 133146. https://doi.org/10.1641/0006-3568(2000)050[0133:BCAMSF]2.3.CO;2

Porras, I.T., International Institute for Environment and Development., 2010. Fair and green?: social impacts of payments for environmental services in Costa Rica. IIED, [London].

Postel, S.L., 2000. Entering an Era of Water Scarcity: The Challenges Ahead. Ecol. Appl. 10, 941-948. https://doi.org/10.1890/1051-0761(2000)010[0941:EAEOWS]2.0.CO;2

Pradhan, P., Fischer, G., van Velthuizen, H., Reusser, D.E., Kropp, J.P., 2015. Closing Yield Gaps: How Sustainable Can We Be? PLoS ONE 10. https://doi.org/10.1371/journal.pone.0129487

Pretty, J.N., Hine, R., 2001. Reducing food poverty with sustainable agriculture: A summary of new evidence. University of Essex Colchester.

Prokopy, L.S., Floress, K., Klotthor-Weinkauf, D., Baumgart-Getz, A., 2008. Determinants of agricultural best management practice adoption: Evidence from the literature. J. Soil Water Conserv. 63, 300-311.

Putnam, R.D., 1993. The prosperous community. Am. Prospect 4, 35-42.

Ramirez, A., 2013. The Influence of Social Networks on Agricultural Technology Adoption. Procedia - Soc. Behav. Sci. 79, 101-116. https://doi.org/10.1016/j.sbspro.2013.05.059 REDDX | Countries [WWW Document], n.d. URL http://reddx.foresttrends.org/country/indonesia/redd_activities (accessed 9.19.17).

Renfroe, D.H., O'Sullivan, P.S., McGee, G.W., 1990. The relationship of attitude, subjective norm, and behavioral intent to the documentation behavior of nurses. Sch. Inq. Nurs. Pract. 4, 47-60; discussion 61-64.

Roco, L., Engler, A., Bravo-Ureta, B., Jara-Rojas, R., 2014. Farm level adaptation decisions to face climatic change and variability: Evidence from Central Chile. Environ. Sci. Policy 44, 86-96.

Rode, J., Gómez-Baggethun, E., Krause, T., 2015. Motivation crowding by economic incentives in conservation policy: A review of the empirical evidence. Ecol. Econ. 117, 270-282. https://doi.org/10.1016/j.ecolecon.2014.11.019

Rosegrant, M. w., Ringler, C., McKinney, D. c., Cai, X., Keller, A., Donoso, G., 2000. Integrated economic-hydrologic water modeling at the basin scale: the Maipo river basin. Agric. Econ. 24, 33-46. https://doi.org/10.1111/j.1574-0862.2000.tb00091.x 
Rouxel, P.L., Heilmann, A., Aida, J., Tsakos, G., Watt, R.G., 2015. Social capital: theory, evidence, and implications for oral health. Community Dent. Oral Epidemiol. 43, 97105.

Rubas, D., 2004. Technology adoption: who is likely to adopt and how does the timing affect the benefits? Texas A\&M University.

Samii, C., Lisiecki, M., Kulkarni, P., Paler, L., Chavis, L., 2014. Effects of payment for environmental services (PES) on deforestation and poverty in low and middle income countries: a systematic review. Campbell Syst. Rev. 10.

Seddon, T., Levin, J., 2013. Educators, Professionalism and Politics: Global Transitions, National Spaces and Professional Projects. Routledge.

Senger, I., Borges, J.A.R., Machado, J.A.D., 2017. Using the theory of planned behavior to understand the intention of small farmers in diversifying their agricultural production. J. Rural Stud. 49, 32-40. https://doi.org/10.1016/j.jrurstud.2016.10.006

Shiferaw, B.A., Okello, J., Reddy, R.V., 2009. Adoption and adaptation of natural resource management innovations in smallholder agriculture: reflections on key lessons and best practices. Environ. Dev. Sustain. 11, 601-619.

Sidibé, A., 2005. Farm-level adoption of soil and water conservation techniques in northern Burkina Faso. Agric. Water Manag. 71, 211-224. https://doi.org/10.1016/j.agwat.2004.09.002

Sloan, S., Edwards, D.P., Laurance, W.F., 2012. Does Indonesia's REDD+ moratorium on new concessions spare imminently threatened forests? Conserv. Lett. 5, 222-231. https://doi.org/10.1111/j.1755-263X.2012.00233.x

Slusher, M.P., Anderson, C.A., 1996. Using causal persuasive arguments to change beliefs and teach new information: The mediating role of explanation availability and evaluation bias in the acceptance of knowledge. J. Educ. Psychol. 88, 110-122. https://doi.org/10.1037/0022-0663.88.1.110

Snapp, S.S., Swinton, S.M., Labarta, R., Mutch, D., Black, J.R., Leep, R., Nyiraneza, J., O'Neil, K., 2005. Evaluating cover crops for benefits, costs and performance within cropping system niches. Agron. J. 97, 322-332.

Southgate, D., Figueroa, E., 2006. Reforming water policies in Latin America: Some lessons from Chile and Ecuador, in: The Water Revolution: Practical Solution to Water Scarcity. International Policy Press, London, UK, pp. 72-91. 
Sponarski, C.C., Vaske, J.J., Bath, A.J., Musiani, M.M., 2014. Salient values, social trust, and attitudes toward wolf management in south-western Alberta, Canada. Environ. Conserv. 41, 303-310. https://doi.org/10.1017/S0376892913000593

Suich, H., Lugina, M., Muttaqin, M.Z., Alviya, I., Sari, G.K., 2017. Payments for ecosystem services in Indonesia. Oryx 51, 489-497. https://doi.org/10.1017/S0030605316000259

TheRoyal Society (London), 2009. Reaping the benefits science and the sustainable intensification of global agriculture. The Royal Society, London.

Tilman, D., 1999. Global environmental impacts of agricultural expansion: the need for sustainable and efficient practices. Proc. Natl. Acad. Sci. 96, 5995-6000.

Tilman, D., Cassman, K.G., Matson, P.A., Naylor, R., Polasky, S., 2002. Agricultural sustainability and intensive production practices. Nature 418, 671-677.

Tran, M., Koncagul, E., Connor, R., 2016. The United Nations World Water Development Report 2016.

Tubiello, F.N., Salvatore, M., Cóndor Golec, R.D., Ferrara, A., Rossi, S., Biancalani, R., Federici, S., Jacobs, H., Flammini, A., 2014. Agriculture, forestry and other land use emissions by sources and removals by sinks. Rome Italy.

UNESCO, 2016. The United Nations world water development report 2016: water and jobs. UNESCO Publishing.

van der Kooij, S., Zwarteveen, M., Boesveld, H., Kuper, M., 2013. The efficiency of drip irrigation unpacked. Agric. Water Manag. 123, 103-110. https://doi.org/10.1016/j.agwat.2013.03.014

van Rijn, F., Nkonya, E., Adekunle, A., 2015. The impact of agricultural extension services on social capital: an application to the Sub-Saharan African Challenge Program in Lake Kivu region. Agric. Hum. Values 32, 597-615. https://doi.org/10.1007/s10460-0149580-9

Vijay, V., Pimm, S.L., Jenkins, C.N., Smith, S.J., 2016. The Impacts of Oil Palm on Recent Deforestation and Biodiversity Loss. PLOS ONE 11, e0159668. https://doi.org/10.1371/journal.pone.0159668

Villalonga-Olives, E., Kawachi, I., 2015. The measurement of social capital. Gac. Sanit. 29, 62-64. https://doi.org/10.1016/j.gaceta.2014.09.006

Vorlaufer, M., Ibanez, M., Juanda, B., Wollni, M., 2017. Conservation versus Equity: Can Payments for Environmental Services Achieve Both? Land Econ. 93, 667-688. https://doi.org/10.3368/le.93.4.667 
Weber, J.M., Kopelman, S., Messick, D.M., 2004. A conceptual review of decision making in social dilemmas: applying a logic of appropriateness. Personal. Soc. Psychol. Rev. Off. J. Soc. Personal. Soc. Psychol. Inc 8, 281-307. https://doi.org/10.1207/s15327957pspr0803_4

Willock, J., Deary, I.J., Edwards-Jones, G., Gibson, G.J., McGregor, M.J., Sutherland, A., Dent, J.B., Morgan, O., Grieve, R., 1999. The Role of Attitudes and Objectives in Farmer Decision Making: Business and Environmentally-Oriented Behaviour in Scotland. J. Agric. Econ. 50, 286-303. https://doi.org/10.1111/j.14779552.1999.tb00814.x

Woolcock, M., 2001. The place of social capital in understanding social and economic outcomes. Can. J. Policy Res. 2, 11-17.

Wossen, T., Berger, T., Di Falco, S., 2015. Social capital, risk preference and adoption of improved farm land management practices in Ethiopia. Agric. Econ. 46, 81-97. https://doi.org/10.1111/agec.12142

Wuepper, D., Ayenew, H.Y., Sauer, J., 2018. Social Capital, Income Diversification and Climate Change Adaptation: Panel Data Evidence from Rural Ethiopia. J. Agric. Econ. 69, 458-475. https://doi.org/10.1111/1477-9552.12237

Yazdanpanah, M., Hayati, D., Hochrainer-Stigler, S., Zamani, G.H., 2014a. Understanding farmers' intention and behavior regarding water conservation in the Middle-East and North Africa: A case study in Iran. J. Environ. Manage. 135, 63-72. https://doi.org/10.1016/j.jenvman.2014.01.016

Yazdanpanah, M., Hayati, D., Hochrainer-Stigler, S., Zamani, G.H., 2014b. Understanding farmers' intention and behavior regarding water conservation in the Middle-East and North Africa: A case study in Iran. J. Environ. Manage. 135, 63-72. https://doi.org/10.1016/j.jenvman.2014.01.016

Yazdanpanah, M., Hayati, D., Hochrainer-Stigler, S., Zamani, G.H., 2014c. Understanding farmers' intention and behavior regarding water conservation in the Middle-East and North Africa: A case study in Iran. J. Environ. Manage. https://doi.org/10.1016/j.jenvman.2014.01.016 


\section{Appendices}

\section{Appendix 1. The SEM input (Mplus 7) - Integral model (TPB, social capital and control variables)}

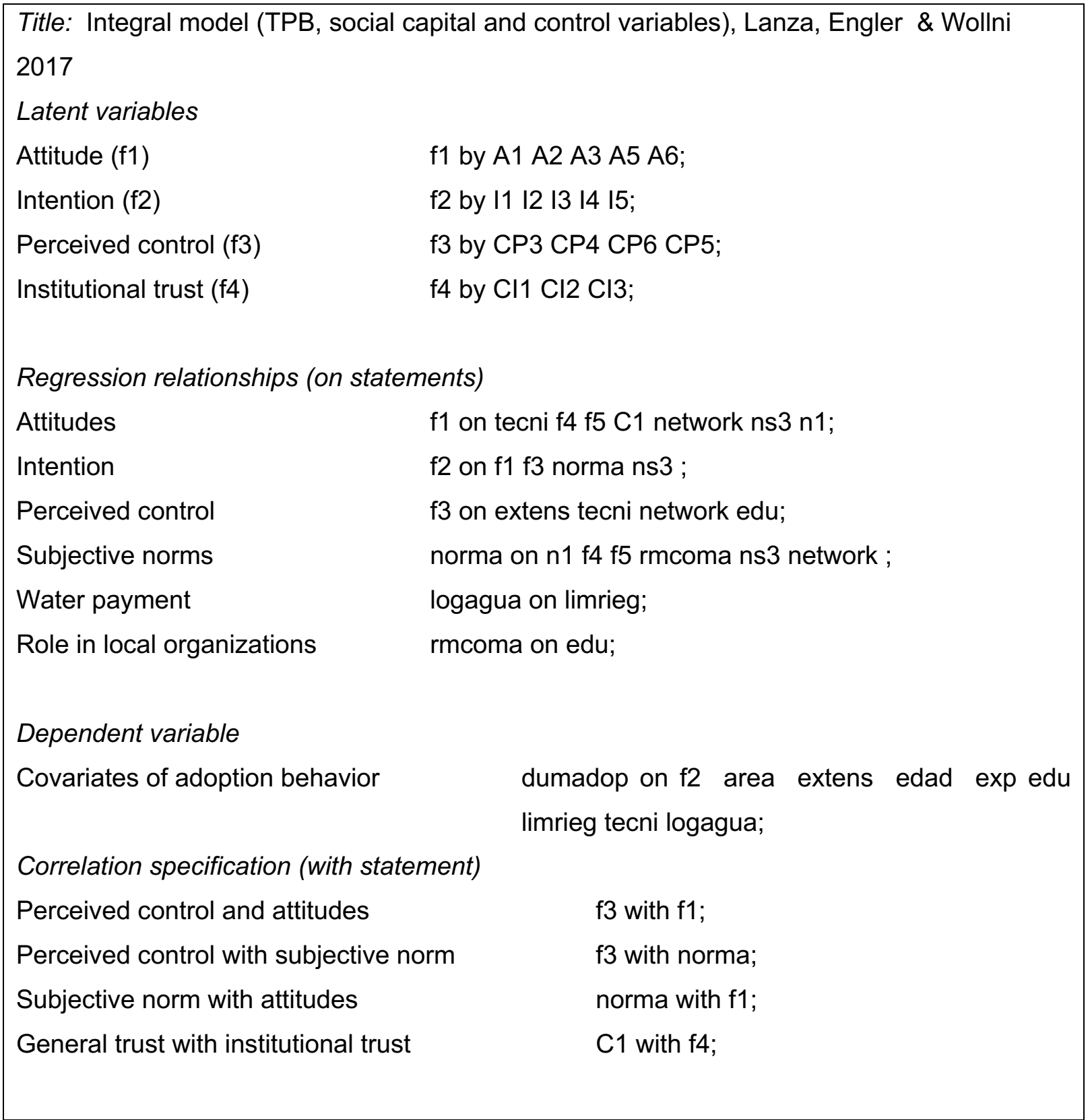




\section{Appendix 2. Items for Latent variables creation}

The results of the robust unweighted least squares (ULSMV) show that Attitudes, perceived control and intentions are latent variables in the model constructed from a set of statements. Table 9 shows the standardized regression coefficients for the individual statements reflecting their relationship with the continuous latent variables. Statements measuring attitude are significant at the $1 \%$ level, with "modern irrigation technology contributes to soil conservation" $(\beta=.893, \mathrm{SE}=.034)$ being the strongest, followed by "modern irrigation technology improves crop management" $(\beta=.862, \mathrm{SE}=.033)$. Subjective norms are related mostly to water community organizations and their approval of the technology and the expectation of other farmers approving the adoption of the technology. With regards to perceived control, all statements are significant at $1 \%$ level, with "I have the knowledge to correctly operate a modern irrigation technology" ( $\beta=.960, \mathrm{SE}=.015)$ having the strongest influence, followed by "I am able to program an irrigation system" ( $\beta=.952$, SE=.017), and "I can effectively implement a modern irrigation system" $(\beta=.916, \mathrm{SE}=.024)$. These results show how important it is that the farmer feels secure about having the knowledge to operate the system. Normally, this information comes through extension services that can be considered bridging networks, and/or fellow farmers that have already implemented the technology (i.e., bonding networks), highlighting the importance of social capital and its influence on intention.

Table 9. Standardized regression coefficients of the relationships for the statements of the continuous latent variables $^{10}$

\begin{tabular}{|c|c|c|c|c|}
\hline & Estimate & S.E & Est/S.E & P-Value \\
\hline \multicolumn{5}{|l|}{ Attitude } \\
\hline Modern irrigation technology contributes to soil conservation & .893 & .034 & 26.358 & .000 \\
\hline Modern irrigation technology improves crop management & .862 & .033 & 26.098 & .000 \\
\hline Investing in modern irrigation technology is profitable & .805 & .035 & 23.181 & .000 \\
\hline \multicolumn{5}{|l|}{ Modern irrigation technology is the solution to facing water } \\
\hline limitations & .779 & .037 & 21.155 & .000 \\
\hline Modern irrigation technology increases yields & 0.764 & .038 & 19.968 & .000 \\
\hline
\end{tabular}

\footnotetext{
${ }^{10}$ The coefficients provided by Mplus for the predictors to observed categorical dependent variable are the results of a probit regression (Muthén and Muthén, 2010).
} 


\section{$\begin{array}{llll}\text { Estimate } & \text { S.E } & \text { Est/S.E } & \text { P-Value }\end{array}$}

\section{Perceived control}

I have the knowledge to correctly operate a modern irrigation

technology

$\begin{array}{llll}.960 & .015 \quad 62.398 \quad .000\end{array}$

I am able to program an irrigation system

.952

$.017 \quad 54.820$

.000

I can effectively implement a modern irrigation system

.916

.024

38.157

.000

I consider myself capable of operating a modern irrigation

technology

$.904 \quad .020 \quad 45.202 \quad .000$

\section{Intention}

I have the intention to be trained in irrigation systems this year

$\begin{array}{llll}.859 & .043 \quad 20.073 \quad .000\end{array}$

I am planning to incorporate instruments for the determination of water requirements

$\begin{array}{llll}.763 \quad .040 \quad 19.285 & .000\end{array}$

I have the intention to hire a consultant to improve planning and maintenance of irrigation systems

$\begin{array}{llll}.713 & .041 & 17.423 & .000\end{array}$

I would be willing to borrow money to adopt modern irrigation systems on the farm

Within the next 12 months I have the intention to adopt modern irrigation systems 


\section{Appendix 3. Survey - Adoption of irrigation technologies by small farmers in the Maule and O'Higgins Region. The role of social capital}
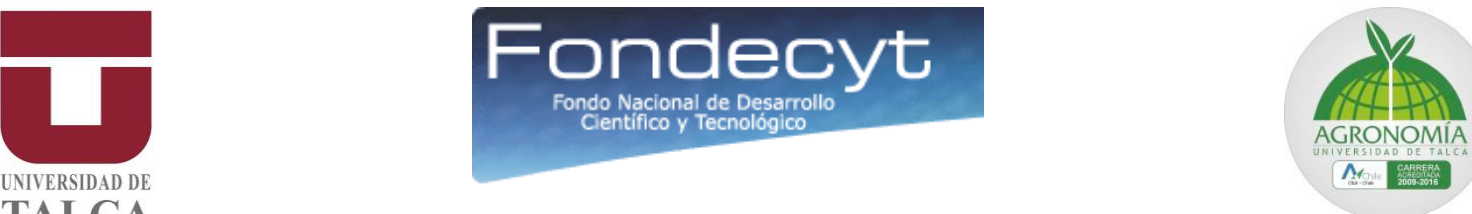

ENCUESTA PROYECTO FONDECYT № 1140615

“ADOPCIÓN DE TECNOLOGÍAS DE RIEGO ENTRE PEQUEÑOS Y MEDIANOS AGRICULTORES DE LA REGIÓN DEL MAULE Y O'HIGGINS:

EL ROL DEL CAPITAL SOCIAL"

Toda información proporcionada tendrá carácter confidencial, donde el manejo de datos solo será de tipo estadístico y NO se facilitará a terceros. La información personal solicitada tiene por único fin el poder fiscalizar el correcto proceso de toma de encuestas.

Dr. Alejandra Engler Palma, Investigador responsable

\begin{tabular}{|l|l|l|l|l|l|}
\hline $\begin{array}{l}\text { Nombre del } \\
\text { encuestad } \\
\text { or }\end{array}$ & $\begin{array}{l}\text { Fech } \\
\text { a }\end{array}$ & & & \\
\hline
\end{tabular}

INFORMACIÓN GENERAL DEL PRODUCTOR

\begin{tabular}{|c|c|c|c|c|c|}
\hline $\begin{array}{l}1 . \\
\text { Número de } \\
\text { identificación }\end{array}$ & & & $\begin{array}{l}2 . \\
\text { Coord. Lat. S } \\
\text { Coord. Long. O }\end{array}$ & & \\
\hline $\begin{array}{ll}\text { 3. } & \\
\text { Tipo } & \text { de } \\
\text { empresa }\end{array}$ & $\begin{array}{c}\text { Unipersona } \\
\text { I }\end{array}$ & Sociedad & $\begin{array}{l}4 . \\
\text { Comuna }\end{array}$ & & \\
\hline $\begin{array}{l}5 . \\
\text { Área total } \\
\text { cultivada }\end{array}$ & as & _hectáre & $\begin{array}{l}6 . \\
\text { Tiempo de viaje } \\
\text { predio - ciudad }\end{array}$ & \multicolumn{2}{|r|}{ _minut } \\
\hline $\begin{array}{l}7 . \\
\text { Superficie } \\
\text { propia /otra }\end{array}$ & \multicolumn{2}{|c|}{$\begin{array}{l}\text { ha } \\
\text { ha }\end{array}$} & $\begin{array}{l}8 . \\
\begin{array}{l}\text { Cargo } \\
\text { contacto }\end{array} \text { del } \\
\end{array}$ & Dueño & Administrador \\
\hline $\begin{array}{l}9 . \\
\text { Teléfono del } \\
\text { contacto }\end{array}$ & & & $\begin{array}{l}10 . \\
\text { Nombre de la } \\
\text { empresa }\end{array}$ & & \\
\hline
\end{tabular}




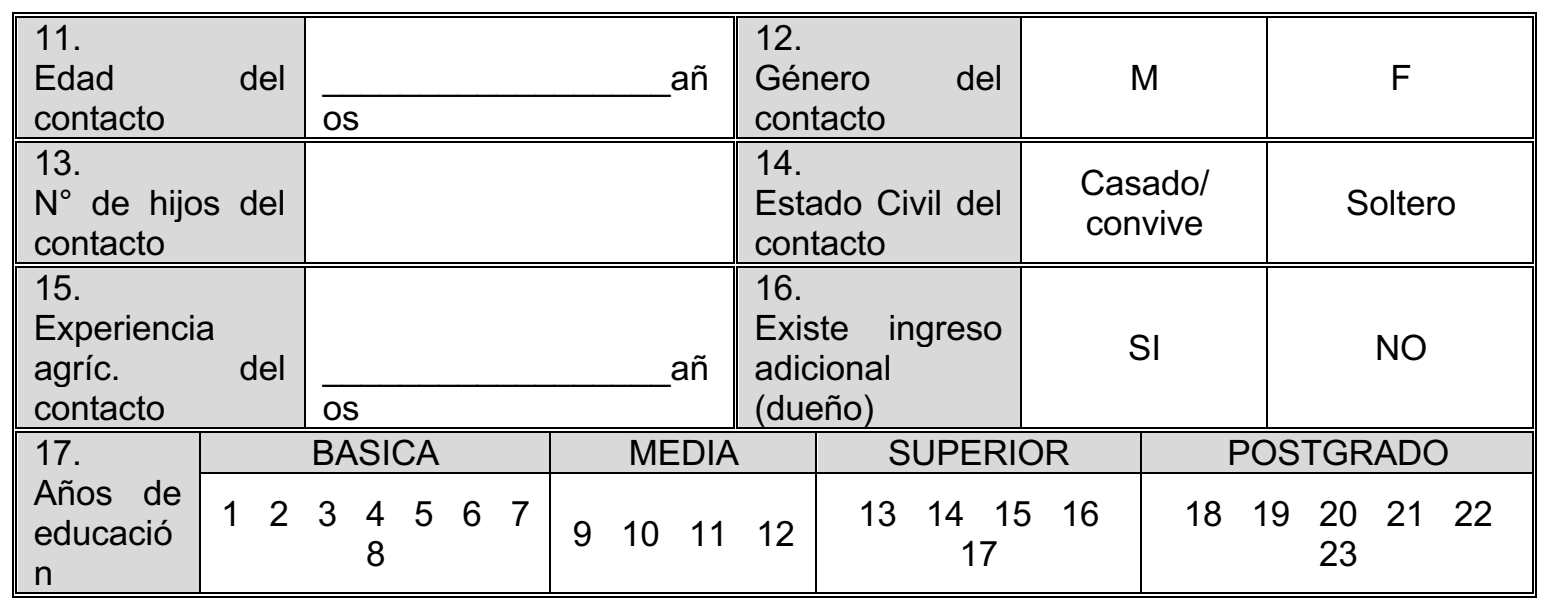

\section{TECNOLOGÍAS DE RIEGO EN VIÑAS}

18. ¿Recibe recomendaciones de riego de parte de algún asesor?

$$
\text { Sí }
$$

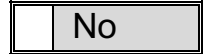

"Si la respuesta es NO sáltese a la pregunta 24"

19. ¿A qué entidad pertenece el asesor que realiza dichas recomendaciones de riego? (puede marcar más de una)

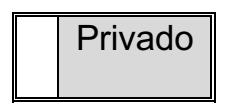

GTT

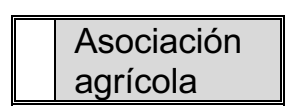

\section{Bodega- \\ Comprador}

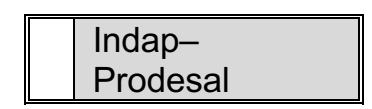

\begin{tabular}{|l|l|}
\hline $\begin{array}{l}\text { Proveedor de } \\
\text { insumos }\end{array}$ \\
\hline
\end{tabular}

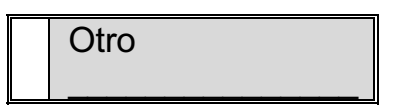

20. ¿Qué tipo de asesor realiza las recomendaciones de riego?

\begin{tabular}{|l|l|}
\hline $\begin{array}{l}\text { Asesor general de } \\
\text { cultivos }\end{array}$ & \\
\hline
\end{tabular}

\begin{tabular}{|l|l|}
\hline $\begin{array}{l}\text { Asesor especialista en } \\
\text { riego }\end{array}$ \\
\hline
\end{tabular}

21. ¿Cómo califica la calidad de la asesoría que recibe?

\begin{tabular}{||l|l|l|l|l|l|l|}
\hline \multicolumn{7}{|c|}{ a) Responsabilidad } \\
\hline 1 & 2 & 3 & 4 & 5 & 6 & 7 \\
\hline
\end{tabular}

\begin{tabular}{||l|l|l|l|l|l|l|}
\hline \multicolumn{7}{|c|}{ b) Conocimientos } \\
\hline 1 & 2 & 3 & 4 & 5 & 6 & 7 \\
\hline
\end{tabular}

22. ¿Cuántas visitas realiza el asesor en el año? $\mathrm{N}^{\circ}$

23. ¿Cuál es el costo por visita del asesor?

$\$$ 
"Sáltese a la pregunta 28"

24. ¿Quién decide cuánto y cuándo regar?

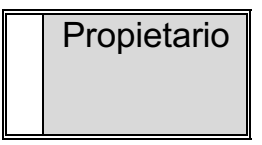

\begin{tabular}{|l|l||}
\hline $\begin{array}{l}\text { Administrador- } \\
\text { Gerente } \\
\text { agrícola }\end{array}$ \\
\hline
\end{tabular}
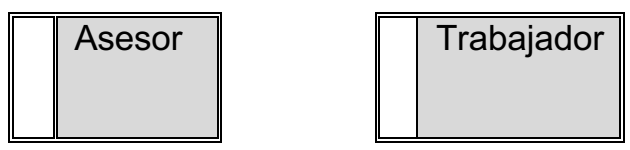

25. ¿Dicha persona ha recibido capacitación formal en riego?
Sí
- No

"Si la respuesta es NO sáltese a la pregunta 28"

26. ¿Quién realizó o dictó esta capacitación formal (la última realizada)?

\begin{tabular}{|l|l|}
\hline $\begin{array}{l}\text { Empresa } \\
\text { de riego }\end{array}$ \\
\hline
\end{tabular}

\begin{tabular}{|l|l||}
\hline $\begin{array}{l}\text { Universidad- } \\
\text { Centro } \\
\text { investigación }\end{array}$ \\
\hline
\end{tabular}

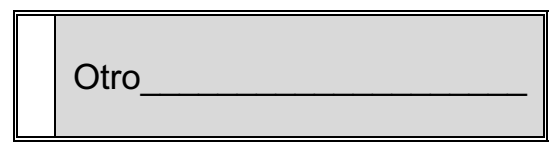

27. ¿Cuántas capacitaciones formales ha tenido en los últimos 3 años?

$\mathrm{N}^{\circ}$

28. ¿En base a qué fuente de información riega sus cultivos? (puede marcar más de una)

\begin{tabular}{|l|}
\hline $\begin{array}{l}\text { Instrumentos } \\
\text { propios }\end{array}$ \\
\hline
\end{tabular}

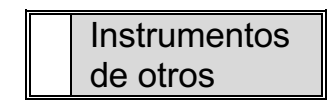

Criterio personal

"Si responde INSTRUMENTOS pase a la pregunta 29, de lo contrario sáltese a la 30"

29. ¿Qué clase de instrumentos se utilizan para definir cuánto y cuándo regar? (puede marcar más de una)

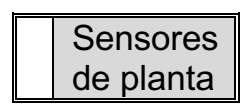
Sensores
de planta

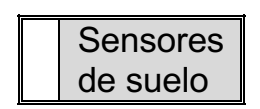
de suelo

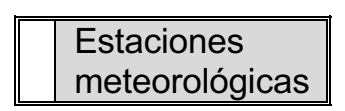

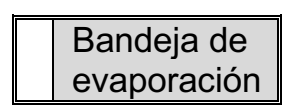

Otros menores

30. ¿Qué entiende por programación de riego?

31. ¿Su comunidad de aguas le provee información sobre requerimiento hídrico de cultivos?

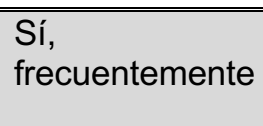

frecuentemente

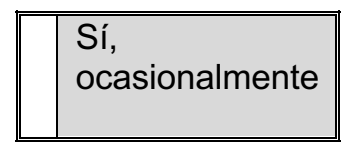

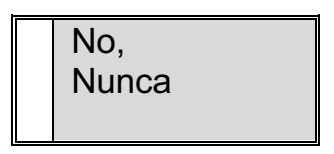

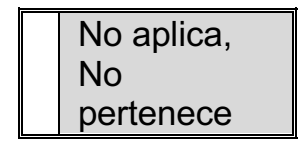

32. ¿Obtiene información sobre requerimiento hídrico de alguna otra organización? Especifique 

No
Sí

33. ¿ A través de qué medios de comunicación obtiene información meteorológica? (puede marcar más de una)

Internet

\begin{tabular}{||c|}
\hline Televisión \\
\hline
\end{tabular}

\begin{tabular}{|l|l|}
\hline & Radio \\
\hline
\end{tabular}

| Diario

Amigos

34. ¿A través de qué medios obtiene información sobre seminarios, charlas, capacitación o nuevas tecnologías y técnicas de producción agrícola? (puede marcar más de una)
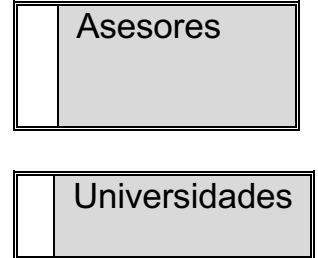
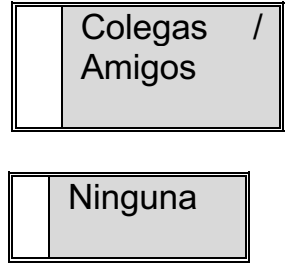
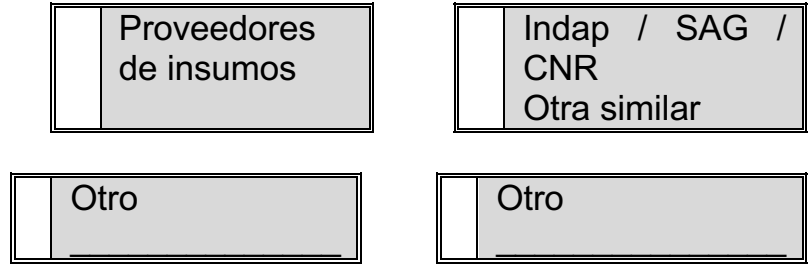

35. ¿Tiene limitaciones de agua para regar?
Sí
No

"Si la respuesta es NO sáltese a la pregunta 38"

36. ¿Cuán frecuentes han sido estas limitaciones de riego en los últimos 3 años?

\section{Muy frecuentes}

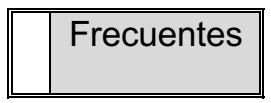

\begin{tabular}{|l|ll|}
\hline \hline & $\begin{array}{l}\text { Muy } \\
\text { frecuentes }\end{array}$ \\
\hline
\end{tabular}

37. ¿A qué motivos atribuye estas limitaciones? (puede marcar más de una)

\begin{tabular}{|l|l|}
\hline \hline & $\begin{array}{l}\text { Cambio } \\
\text { climático }\end{array}$ \\
\hline
\end{tabular}

\begin{tabular}{|l|l|}
\hline $\begin{array}{l}\text { Gestión de la } \\
\text { comunidad } \\
\text { agua }\end{array}$ \\
\hline
\end{tabular}

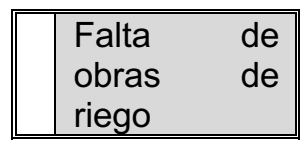

\begin{tabular}{|l|lr|}
\hline $\begin{array}{l}\text { Uso } \\
\text { agrícola } \\
\text { recurso }\end{array}$ & $\begin{array}{l}\text { no- } \\
\text { del }\end{array}$ \\
\hline
\end{tabular}

38. ¿Ha participado en algún proyecto de transferencia tecnológica en riego?
Sí
No

"Si la respuesta es NO sáltese a la pregunta 43"

39. ¿Qué tipo de participación tuvo en el proyecto? (puede marcar más de una)
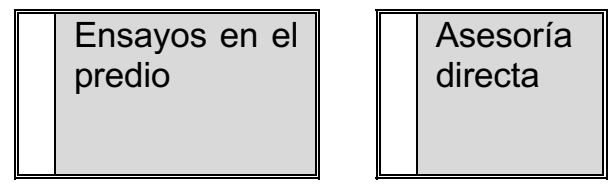

\begin{tabular}{||l|l|}
\hline & $\begin{array}{l}\text { Cursos } \\
\text { formales } \\
\text { (medio año o } \\
\text { más) }\end{array}$ \\
\hline
\end{tabular}

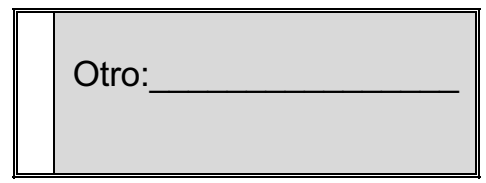


40. ¿Qué entidad organizó el proyecto?

41. ¿Cuánto tiempo ha participado o participó en dicho proyecto (años)?

42. ¿Qué nota le pondría al apoyo recibido (de 1 a 7 )?

43. Indique el "tiempo de riego por hectárea si tiene riego tecnificado" ó el "número de riegos por hectárea si tiene riego gravitacional" en cada mes de la temporada. Si practica ambos sistemas contesta ambas filas.

\begin{tabular}{|c|c|c|c|c|c|c|c|c|c|}
\hline & $\begin{array}{c}\text { Septiemb } \\
\text { re }\end{array}$ & $\begin{array}{c}\text { Octubr } \\
\text { e }\end{array}$ & $\begin{array}{c}\text { Noviemb } \\
\text { re }\end{array}$ & $\begin{array}{c}\text { Diciemb } \\
\text { re }\end{array}$ & $\begin{array}{c}\text { Ener } \\
0\end{array}$ & $\begin{array}{c}\text { Febrer } \\
0\end{array}$ & $\begin{array}{c}\text { Marz } \\
0\end{array}$ & $\begin{array}{c}\text { Abri } \\
\text { I }\end{array}$ & $\begin{array}{c}\text { May } \\
0\end{array}$ \\
\hline $\begin{array}{c}\text { Cantida } \\
\text { d } \\
\left(\mathrm{N}^{\circ}\right)\end{array}$ & & & & & & & & & \\
\hline $\begin{array}{l}\text { Tiempo } \\
\text { (horas) }\end{array}$ & & & & & & & & & \\
\hline
\end{tabular}

44. Si se arrienda agua en su sector, ¿Cuál es el valor de un día de agua ó del metro cúbico?

$\$$ /día

45. ¿Cuenta con riego tecnificado en su predio?

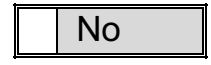

"Si la respuesta es SI sáltese a la pregunta 47"

46. ¿Por qué motivos no cuenta con riego tecnificado? (puede marcar más de una)

\begin{tabular}{|l|l|}
\hline No conozco \\
la tecnología
\end{tabular}

\begin{tabular}{|l|l|}
\hline $\begin{array}{l}\text { Tengo agua } \\
\text { en } \\
\text { abundancia }\end{array}$ \\
\hline
\end{tabular}
$/ \mathrm{m}^{3}$

"Esta sección de la encuesta terminó"

47. ¿Quién realizó la instalación de su sistema de riego tecnificado?

\begin{tabular}{|l|l|}
\hline \hline Empresa - personal externo \\
\hline
\end{tabular}

"Si la respuesta es PROPIETARIO - PERSONAL INTERNO sáltese a la pregunta 49" 
48. ¿Cómo califica la calidad de la empresa o personal que realizó la instalación del sistema de riego?

\begin{tabular}{|l|l|l|l|l|l|l|}
\hline \multicolumn{7}{|c|}{ a) Responsabilidad } \\
\hline 1 & 2 & 3 & 4 & 5 & 6 & 7 \\
\hline
\end{tabular}

\begin{tabular}{||l|l|l|l|l|l|l|}
\hline \multicolumn{7}{|c|}{ b) Conocimientos } \\
\hline 1 & 2 & 3 & 4 & 5 & 6 & 7 \\
\hline
\end{tabular}

49. ¿Ha recibido subsidios de inversión al riego?
Sí
\begin{tabular}{|l|l|}
\hline No \\
\hline
\end{tabular}

"Si la respuesta es NO sáltese a la pregunta 51"

50. ¿Qué porcentaje de bonificación recibió?

Si cuenta con más de un sistema, indique el promedio $\%$

51. ¿Qué clase de mantenciones realiza al sistema de riego anualmente? (puede marcar más de una)

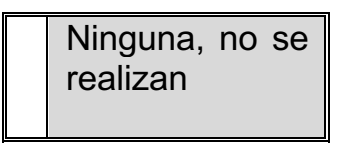

\begin{tabular}{||l|l||}
\hline \hline $\begin{array}{l}\text { Limpieza de } \\
\text { boquillas- } \\
\text { goteros }\end{array}$ \\
\hline
\end{tabular}
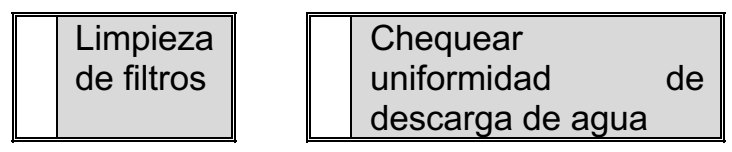

"Si la respuesta es NINGUNA esta sección de la encuesta terminó"

52. ¿Quién realiza las mantenciones al sistema de riego?

Empresa - personal externo

\begin{tabular}{|l|l|}
\hline $\begin{array}{l}\text { Propietario - personal } \\
\text { interno }\end{array}$ \\
\hline
\end{tabular}

"Si la respuesta es PROPIETARIO - PERSONAL INTERNO esta sección de la encuesta terminó"

53. ¿Cómo califica la calidad del servicio que recibe?

\begin{tabular}{|l|l|l|l|l|l|l|}
\hline \multicolumn{7}{|c|}{ a) Responsabilidad } \\
\hline 1 & 2 & 3 & 4 & 5 & 6 & 7 \\
\hline
\end{tabular}

\begin{tabular}{||c|c|c|c|c|c|c|}
\hline \multicolumn{7}{|c|}{ b) Conocimientos } \\
\hline 1 & 2 & 3 & 4 & 5 & 6 & 7 \\
\hline
\end{tabular}




\section{RENTABILIDAD DEL VIÑEDO}

54. Complete el siguiente cuadro para las 4 cepas más relevantes en su predio, listadas en orden de superficie. Información debe ser de temporada anterior. Indique la fila con mayor superficie al final de esta página.

\begin{tabular}{|c|c|c|c|c|c|c|c|c|c|c|c|}
\hline $\begin{array}{c}\text { Cep } \\
\mathbf{a}\end{array}$ & Nombre & $\begin{array}{c}\text { Tipo de Conducción } \\
\text { y Destino }\end{array}$ & $\begin{array}{c}\text { Área } \\
\text { (ha) }\end{array}$ & $\begin{array}{l}\text { Rdto. } \\
\text { (t/ha) }\end{array}$ & $\begin{array}{c}\text { Año } \\
\text { plan } \\
\text { t. }\end{array}$ & $\begin{array}{l}\text { Marco plant. } \\
(m \times m)\end{array}$ & $\begin{array}{c}\text { Precio } \\
(\$ / \mathrm{Kg})\end{array}$ & $\begin{array}{c}\text { * Sist. } \\
\text { Manej } \\
0\end{array}$ & $\begin{array}{c}\text { * } \\
\text { Sist. } \\
\text { Rieg } \\
0\end{array}$ & $\begin{array}{l}\text { Número de } \\
\text { Got-Asp/ ha }\end{array}$ & $\underset{(\mathrm{L} / \mathrm{Hr})}{\text { Caudal }}$ \\
\hline \multirow{4}{*}{1} & & Espaldera Reserva & & & & & & & & & \\
\hline & & Espaldera Varietal & & & & & & & & & \\
\hline & & Parrón Reserva & & & & & & & & & \\
\hline & & Parrón Varietal & & & & & & & & & \\
\hline \multirow{4}{*}{2} & & Espaldera Reserva & & & & & & & & & \\
\hline & & Espaldera Varietal & & & & & & & & & \\
\hline & & Parrón Reserva & & & & & & & & & \\
\hline & & Parrón Varietal & & & & & & & & & \\
\hline \multirow{4}{*}{3} & & Espaldera Reserva & & & & & & & & & \\
\hline & & Espaldera Varietal & & & & & & & & & \\
\hline & & Parrón Reserva & & & & & & & & & \\
\hline & & Parrón Varietal & & & & & & & & & \\
\hline \multirow{4}{*}{4} & & Espaldera Reserva & & & & & & & & & \\
\hline & & Espaldera Varietal & & & & & & & & & \\
\hline & & Parrón Reserva & & & & & & & & & \\
\hline & & Parrón Varietal & & & & & & & & & \\
\hline
\end{tabular}

* Sistema de riego:

1) Goteo

2) Aspersión

3) Cinta- Californiano

4) Surco-Tendido 
Escriba la fila con mayor superficie (cepa, conducción y destino) para responder preguntas 55 y 56 : 
55. Complete costos de insumos incurridos por hectárea en la temporada anterior Información debe ser de la fila con mayor superficie identificada en el cuadro anterior.

"Si el encuestado no tiene a mano el precio del producto basta con anotar claramente el nombre "

\begin{tabular}{|c|c|c|c|c|c|c|c|}
\hline \multicolumn{2}{|c|}{ Item } & \multirow[t]{2}{*}{ Nombre } & \multirow[t]{2}{*}{$\begin{array}{l}\text { Númer } \\
\text { o } \\
\text { aplicac }\end{array}$} & \multirow{2}{*}{$\begin{array}{c}\text { Forma } \\
\text { aplicac. (JH - } \\
\text { JM - FR) }\end{array}$} & \multirow{2}{*}{$\begin{array}{c}\text { Cant. } \\
\text { por } \\
\text { aplicaci } \\
\text { on } \\
\end{array}$} & \multirow{2}{*}{$\begin{array}{c}\text { Unidad } \\
(\mathbf{K g}, \mathbf{g}-\mathrm{L}, \\
\mathrm{cc})\end{array}$} & \multirow[t]{2}{*}{$\begin{array}{c}\text { Precio } \\
\text { (\$/L - \$/Kg) }\end{array}$} \\
\hline \multirow{3}{*}{$\begin{array}{l}\text { o } \\
\stackrel{0}{0} \\
\stackrel{0}{<}\end{array}$} & A) & & & & & & \\
\hline & B) & & & & & & \\
\hline & C) & & & & & & \\
\hline \multirow{3}{*}{ 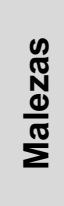 } & A) & & & & & & \\
\hline & B) & & & & & & \\
\hline & C) & & & & & & \\
\hline \multirow{3}{*}{ 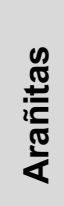 } & A) & & & & & & \\
\hline & B) & & & & & & \\
\hline & C) & & & & & & \\
\hline \multirow{3}{*}{ 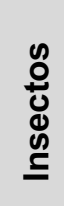 } & A) & & & & & & \\
\hline & B) & & & & & & \\
\hline & C) & & & & & & \\
\hline \multirow{3}{*}{$\begin{array}{l}\stackrel{n}{\circ} \\
\stackrel{\circ}{0} \\
\stackrel{0}{x}\end{array}$} & A) & & & & & & \\
\hline & B) & & & & & & \\
\hline & C) & & & & & & \\
\hline
\end{tabular}

56. Complete "costos de labores" ó "cantidad de trabajo incurrido" por hectárea en la temporada anterior

Aquellas labores realizadas con maquinaria propia se responden como Número de Jornadas Máquina

\begin{tabular}{|c|c|c|c|c|c|c|}
\hline \multirow[b]{2}{*}{ Labores } & \multicolumn{3}{|c|}{ Mano de obra } & \multicolumn{3}{|c|}{ Maquinaria } \\
\hline & $\begin{array}{c}\text { Costo total } \\
\text { (\$) }\end{array}$ & $\begin{array}{c}\text { Cantidad } \\
\left(\mathbf{N}^{\circ}\right)\end{array}$ & $\begin{array}{l}\text { Unidad } \\
\text { (JH - JM) }\end{array}$ & $\begin{array}{c}\text { Costo total } \\
(\$)\end{array}$ & $\begin{array}{c}\text { Cantidad } \\
\left(\mathrm{N}^{\circ}\right)\end{array}$ & $\begin{array}{l}\text { Unidad } \\
(\mathrm{JH}-\mathrm{JM})\end{array}$ \\
\hline \begin{tabular}{ll|} 
A) Poda & y \\
amarre
\end{tabular} & & & & & & \\
\hline B) Cosecha & & & & & & \\
\hline C) Desbrote & & & & & & \\
\hline D) Chapoda & & & & & & \\
\hline $\begin{array}{l}\text { E) Control } \\
\text { malezas }\end{array}$ & & & & & & \\
\hline E) Resto labores & & & & & & \\
\hline
\end{tabular}

CAPITAL SOCIAL 
Respond in scale from 1 to 5 according to their level of agreement with the following statements. 1 = Strongly Disagree; 2 = Disagree; $3=$ Neutral; 4 = Agree; 5 = Strongly Agree

\begin{tabular}{|c|c|c|c|c|c|c|c|}
\hline & \multicolumn{2}{|l|}{ Confianza } & 1 & 2 & 3 & 4 & 5 \\
\hline 57. & \multicolumn{2}{|l|}{$\begin{array}{l}\text { I can trust the people around me without the need to be } \\
\text { cautious }\end{array}$} & & & & & \\
\hline 58. & \multicolumn{2}{|l|}{ Farmers are reliable people } & & & & & \\
\hline 59. & \multicolumn{2}{|l|}{$\begin{array}{l}\text { I believe that other farmers would not harm me for their own } \\
\text { benefit }\end{array}$} & & & & & \\
\hline 60. & \multicolumn{2}{|l|}{$\begin{array}{l}\text { The people of the neighborhood works together to solve } \\
\text { problems of water availability }\end{array}$} & & & & & \\
\hline 61. & \begin{tabular}{|l|} 
In the last five years it has increased confidence among \\
producers who belong to the Water Community
\end{tabular} & N/A & & & & & \\
\hline 62. & \multicolumn{2}{|l|}{$\begin{array}{l}\text { I could lean on friends if I require not too large amounts of } \\
\text { money }\end{array}$} & & & & & \\
\hline 63. & \multicolumn{2}{|l|}{$\begin{array}{l}\text { Agricultural associations work for the welfare of farmers and the } \\
\text { agricultural sector }\end{array}$} & & & & & \\
\hline & \multicolumn{2}{|l|}{ Indique su grado de confianza en: } & 1 & 2 & 3 & 4 & 5 \\
\hline 64. & \multicolumn{2}{|l|}{ Municipalities } & & & & & \\
\hline 65. & \multicolumn{2}{|l|}{ Public Institutions } & & & & & \\
\hline 66. & \multicolumn{2}{|l|}{ Th estate of Chile } & & & & & \\
\hline 67. & Water Communities & N/A & & & & & \\
\hline 68. & Channel Association & $\mathrm{N} / \mathrm{A}$ & & & & & \\
\hline \multirow[t]{2}{*}{69.} & Supervisory Council & $\mathrm{N} / \mathrm{A}$ & & & & & \\
\hline & \multicolumn{2}{|l|}{ Normas } & 1 & 2 & 3 & 4 & 5 \\
\hline 70. & \multicolumn{2}{|l|}{ Always I obey the laws and regulations (labor, transit, tax, etc.) } & & & & & \\
\hline 71. & \multicolumn{2}{|l|}{$\begin{array}{l}\text { When the people around me have a hard time whenever I help } \\
\text { them }\end{array}$} & & & & & \\
\hline 72. & \multicolumn{2}{|l|}{ I always vote in presidential and municipal elections } & & & & & \\
\hline 73. & \multicolumn{2}{|l|}{ I disapprove when farmers receive benefits that do not qualify } & & & & & \\
\hline 74. & \multicolumn{2}{|l|}{ My workers have better working conditions than other farms } & & & & & \\
\hline 75. & I always pay my workers and service providers timely & & & & & & \\
\hline
\end{tabular}

\begin{tabular}{|c|c|c|c|c|c|c|c|}
\hline & \multicolumn{2}{|l|}{ Redes formales } & 1 & 2 & 3 & 4 & 5 \\
\hline 76. & $\begin{array}{l}\text { I go to all the meetings of the associations to which I } \\
\text { belong (except for emergencies) }\end{array}$ & $\mathrm{N} / \mathrm{A}$ & & & & & \\
\hline 77. & $\begin{array}{l}\text { My opinion is considered in agricultural associations to } \\
\text { which I belong }\end{array}$ & $\mathrm{N} / \mathrm{A}$ & & & & & \\
\hline 78. & I attend lectures, conferences or seminars related to agricul & |lture & & & & & \\
\hline
\end{tabular}




\begin{tabular}{|c|c|c|c|c|c|c|}
\hline 79. & $\begin{array}{l}\text { When attending agricultural events, my participation is usually } \\
\text { more active than others }\end{array}$ & & & & & \\
\hline 80. & $\begin{array}{l}\text { I know and I am linked regularly with professionals and experts } \\
\text { of agriculture }\end{array}$ & & & & & \\
\hline 81. & $\begin{array}{l}\text { Organizations interact to improve the service and information } \\
\text { they provide to farmers }\end{array}$ & & & & & \\
\hline \multirow[t]{2}{*}{82.} & $\begin{array}{l}\text { I have participated in non-agricultural voluntary organizations } \\
\text { (religious, cultural, political, community, etc.) }\end{array}$ & & & & & \\
\hline & Redes informales & 1 & 2 & 3 & 4 & 5 \\
\hline 83. & In the work field, I often communicate with neighboring farmers & & & & & \\
\hline 84. & $\begin{array}{l}\text { I spend time with my friends because I consider important to } \\
\text { share with them }\end{array}$ & & & & & \\
\hline 85. & $\begin{array}{l}\text { I always support my farming neighbors when they have a } \\
\text { problem }\end{array}$ & & & & & \\
\hline 86. & \begin{tabular}{|l|l|} 
I maintain frequent contact with representatives of the \\
water community
\end{tabular} & & & & & \\
\hline 87. & $\begin{array}{l}\text { I organize meetings with producers and / or consultants to } \\
\text { acquire new knowledge in agriculture }\end{array}$ & & & & & \\
\hline
\end{tabular}

\section{COMPORTAMIENTO PLANIFICADO}

Respond in scale from 1 to 5 according to their level of agreement with the following statements. 1 = Strongly Disagree; 2 = Disagree; 3 = Neutral; 4 = Agree; 5 = Strongly Agree

\begin{tabular}{|l|l|l|l|l|l|l||}
\cline { 2 - 6 } \multicolumn{1}{l|}{ Actitudes } & $\mathbf{1}$ & $\mathbf{2}$ & $\mathbf{3}$ & $\mathbf{4}$ & $\mathbf{5}$ \\
\hline 88. & The irrigation technology improves crop management & & & & & \\
\hline 89. & Investing in irrigation technology is profitable & & & & & \\
\hline 90. & The irrigation technology increase yields & & & & \\
\hline 91. & Investment in irrigation technology is relatively low for farmers & & & & & \\
\hline 92. & $\begin{array}{l}\text { The irrigation technology is the solution to address problems of } \\
\text { water shortage }\end{array}$ & & & & \\
\hline 93. & The irrigation systems promotes soil conservation & & & & \\
\hline \hline 94. & $\begin{array}{l}\text { The water community which I belong expect or expected } \\
\text { me to adopt modern irrigation systems }\end{array}$ & $\mathbf{N}$ & $\mathbf{2}$ & $\mathbf{3}$ & $\mathbf{4}$ & $\mathbf{5}$ \\
\hline 95. & \begin{tabular}{l} 
Other farmers see or saw good I adopt modern irrigation \\
\hline 96.
\end{tabular} & $\begin{array}{l}\text { I adopted or I would adopt irrigation technology because it helps } \\
\text { to conserve water resources }\end{array}$ & & & & \\
\hline 97. & $\begin{array}{l}\text { The nearby community perceives me as a farmer who cares } \\
\text { about the environment }\end{array}$ & & & & & \\
\hline 98. & $\begin{array}{l}\text { I share information with other farmers about management } \\
\text { techniques to improve agricultural production }\end{array}$ & & & & & \\
\hline \hline
\end{tabular}




\begin{tabular}{|c|c|c|c|c|c|c|}
\hline 100. & $\begin{array}{l}\text { I count with people or companies in which I could lean to } \\
\text { implement modern irrigation }\end{array}$ & & & & & \\
\hline 101. & $\begin{array}{l}\text { I have knowledge to successfully operate a modern irrigation } \\
\text { system }\end{array}$ & & & & & \\
\hline 102. & I am able to program an irrigation system & & & & & \\
\hline 103. & I can effectively implement a modern irrigation system & & & & & \\
\hline \multirow[t]{2}{*}{104.} & $\begin{array}{l}\text { I consider that the operation of a technology irrigation system is } \\
\text { easy }\end{array}$ & & & & & \\
\hline & Intención conductual & 1 & 2 & 3 & 4 & 5 \\
\hline 105. & $\begin{array}{l}\text { Within this or next year I have planned to adopt modern } \\
\text { irrigation systems }\end{array}$ & & & & & \\
\hline 106. & $\begin{array}{l}\text { I'm planning to incorporate instruments for the determination of } \\
\text { water requirements }\end{array}$ & & & & & \\
\hline 107. & $\begin{array}{l}\text { I would be willing to borrow money to adopt modern irrigation } \\
\text { systems on the farm }\end{array}$ & & & & & \\
\hline 108. & I have the intention to be trained in irrigation systems this year & & & & & \\
\hline 109. & $\begin{array}{l}\text { I have the intention to hire a consultant to improve planning and } \\
\text { maintenance of irrigation system }\end{array}$ & & & & & \\
\hline 110. & \begin{tabular}{|l|l|} 
I have the intention to offer to be part of the leadership of & N/A \\
the water community &
\end{tabular} & & & & & \\
\hline
\end{tabular}

\section{NETWORKING}

111. Respecto a sus relaciones comerciales, de colegas y amistades indique:

\begin{tabular}{||l|l|l||}
\hline \multicolumn{1}{|c|}{ Grupo } & $\begin{array}{c}\text { Número con los } \\
\text { que se relaciona }\end{array}$ & $\begin{array}{c}\text { Cercanía de relación promediada } \\
\text { (Alta/ Media / Baja) }\end{array}$ \\
\hline Proveedores de insumos & & \\
\hline Compradores de uva & & \\
\hline Entidades financieras & & \\
\hline Empresas certificadoras & & \\
\hline Colegas & & \\
\hline Amigos & & \\
\hline
\end{tabular}

112. Indique su participación en las siguientes entidades, en hasta 3 asociaciones agrícolas y en hasta 3 asociaciones no agrícolas a las que pertenezca (considere hobbies o pasatiempos).

\begin{tabular}{|c|c|c|c|c|l|c||}
\hline Entidad & $\begin{array}{c}\text { Participa } \\
\text { (Si/No) }\end{array}$ & $\begin{array}{c}\text { Desde } \\
\text { cuánd } \\
\text { O(Año) }\end{array}$ & $\begin{array}{c}\text { Asistenci } \\
\text { a } \\
(\%)\end{array}$ & $\begin{array}{c}\text { Ha } \\
\text { tenid } \\
\text { o rol }\end{array}$ & $\begin{array}{l}\text { Particip. } \\
\text { persona }\end{array}$ & $\begin{array}{c}\text { Beneficios } \\
\text { de }\end{array}$ \\
\hline \hline
\end{tabular}




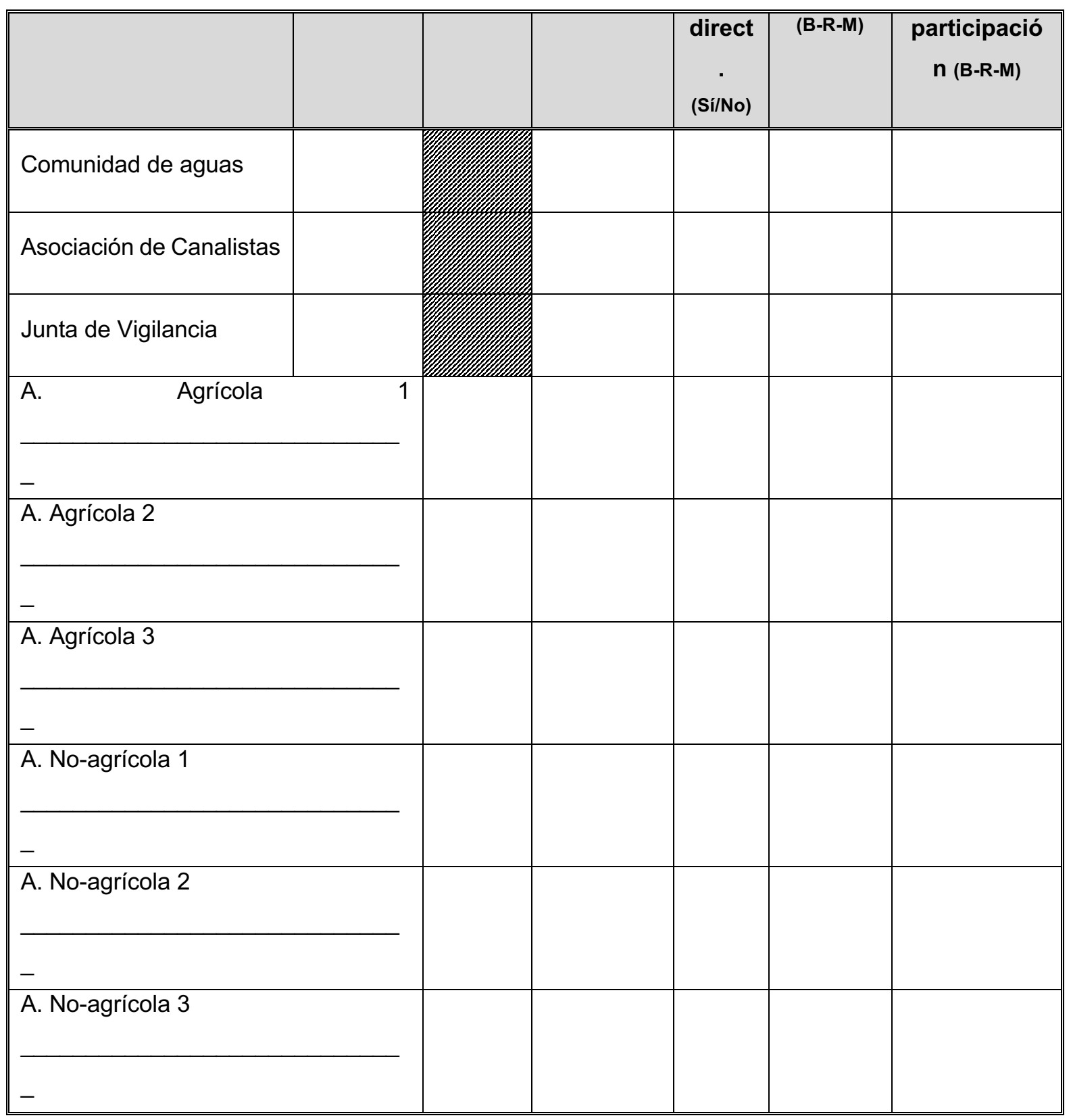

113. De los productores de viñas que conoce, cuántos SI tienen riego tecnificado $\mathrm{N}^{\circ}$

114. De los productores de viñas que conoce, cuántos NO tienen riego tecnificado $\mathrm{N}^{\circ}$ 


\section{Appendix 4. Instructions Investment Game}

The workshop comprises:

1. Sign-in (location and arrival)

2. Introduction and agenda (an introduction of the experimenter, enumerators and the project)

3. Warm-up Quiz

4. Instructions and examples

5. Hypothetical and non-hypothetical decisions

6. Post-experimental survey

7. Payment (voucher)

\section{Sign-in (location and arrival)}

- Each participant is signed in by stating his/her name and showing the invitation letter. An enumerator accompanies the participant to a randomly assigned seat, which is the participant's location throughout the session.

- The experiment is conducted in session of 9 participants in classrooms in local schools or kindergartens.

- The typical layout of the room is as follows:

\begin{tabular}{|l|l|l|}
\hline \multicolumn{3}{|l|}{ Front of the room (experimenter, and white board) } \\
\hline Seat 1 & Seat 4 & Seat 7 \\
\hline Seat 2 & Seat 5 & Seat 8 \\
\hline Seat 3 & Seat 6 & Seat 9 \\
\hline Back of the room (Enumerators) \\
\hline
\end{tabular}

Notes:

- Text in italics is not part of the instructions.

- The instructions are explained orally by the experimenter in the local language (Bahasa Indonesia).

\section{Introduction and agenda}

Good afternoon and welcome to this workshop. Before we start we would like to thank you for your assistance. The experimenter introduces himself, the enumerators and the project, typically as follows: This workshop is organized by the EFFORTS project that aims to understand the decisions that farmers make associated to the four transformation systems: forest, rubber agroforestry, rubber and oil palm monoculture. The project is affiliated to the 
University of Göttingen, Germany, University of Jambi and IPB University of Bogor. The results will used for academic purpose only. We have been holding workshops with farmers in three other villages, e.g. , in Batanghari district.

In this workshop you can earn some money, which will be given to you as a voucher for the shop in your village. Your earnings in this workshop depend on your decisions and the decisions of your group members. In other words, you can influence the amount of money the group members earn and your earnings will be influenced by your group members. Today's workshop includes the following steps. First, we explain the instructions of the different tasks on decision making. Then you will do two hypothetical runs by yourself, before we will start with the actual decision rounds. At the end of the workshop you receive the earnings you have generated in this workshop, as a food voucher, which can be made payable in the local shop in your village. The workshops will take approximately two hours.

Some general comments:

- Please don't use your mobile phone throughout the workshop.

- The workshop in which you participate now is most likely different from the ones your neighbors in this village have already participated. Hence comments you might have heard in the last days, do not apply necessarily for your session.

- All decisions you make or answers you give during the workshop will remain private, confidential and anonymous. Only the number tags that you will receive in a moment will help us to distinguish your answers. So neither the other session members no the experimenter team are able to assign you as a person to a specific decision or earning.

- Since all your decisions are private, don't talk to each other anymore. Please do not discuss with your neighbor.

- Please follow these instructions carefully, so that everybody can make sure that you understood the explanation. If you have any questions, please raise your hands. A member of the research team will come to you and answer your questions.

Do you have any questions so far?

\section{Warm-up Quiz}

We will start today's workshop with a short warm-up exercise. The experimenter hands out the questionnaires to the participants. Three enumerators assist the participants in filling out the questionnaire. The exercise contains four different questions. It is not at test; so you don't need to worry if they seem difficult. Please fill out the questions by yourself and do not discuss it with your neighbors. When you have finished, please turn round the sheets. Questions are 
asked with regard to subtraction and addition of numbers. This basically enables the participants to start thinking about the material and decisions they will be presented with during the workshop. After all participants have finished the sheets were collected by enumerators.

\section{Instructions}

Posters are displayed on a large white board in front of the room to explain the basics of the experiment. In addition, the experimental material, such as envelopes, decision cards and stickers are used by the experimenter to explain the decision making progress.

\subsection{What you need to do during the workshop?}

In this workshop you will play in groups of 3 people. It means that two other people in this session will be in your group. You don't know and will never know who is in your group. The groups remain the same throughout the whole workshop.

In this session you can own either 5 or 10 ha of land. Each of you will choose one of these brown closed envelopes at the beginning of the session. In the envelope you find these green stickers. One sticker represents one ha. So you will find in your chosen envelope either 5 or 10 stickers in a row, indicating 5 or 10 ha. Whether you receive 5 or 10 ha depend on the envelope you choose at the beginning of the session. It indicates it is completely random how many ha you receive and cannot be influenced by you or others in the group. Experimenter shows both the brown envelope, one sticker and the row of 5 and 10 stickers respectively.

Then you have to decide what you want to plant on your land. You can choose between two production systems: Oil palm and Jungle rubber. You can decide how many ha you plant with oil palm and how many ha you plant with jungle rubber. Experimenter shows a picture of oil palm monoculture plantation and jungle rubber system, respectively. Even though, I guess you are familiar with these two production systems, I would like to briefly introduce them to you. Here you can see a picture of an oil palm plantation, where the oil palms are planted in rows and fertilizer and herbicides are applied. This is a picture of a jungle rubber plot. In jungle rubber, you can find besides rubber trees also other trees like Rambutan, Durian, Meranti and fertilizer and herbicides are seldom used. Compared to oil palm, jungle rubber is good for the environment: soil is healthier, more water is available and the number of birds and mammals is higher. As in real life the earnings in this session depend on what you plant on your ha. The earnings from oil palm and jungle rubber differ. Oil palm generates a higher profit per ha than jungle rubber. 
So far any questions? To wrap up, you receive either 5 or 10 ha and you have to decide how many you plant with oil palm plantation and jungle rubber, respectively. While jungle rubber is better for the environment, oil palm generated higher earnings.

\subsection{How much can you earn in this game?}

The experimenter displays a large earning table on the white board.

Here you can see an earning table. The earning table of one decision round remains here until you have made your decision that you can look up the earnings again during your decision making process. We will go slowly through it. As I already mentioned, the amount on the voucher that you can earn in this workshop, depends on the decision on how many hectares you cultivate oil palm and jungle rubber respectively.

The earnings that you receive per ha oil palm and jungle rubber depend on the amount of land that you own. Participants with 5 ha look their earnings up here; participants with 10 ha look their earnings up here. Experimenter points at the respective columns. Suppose that you own 5 ha: One ha planted with oil palm gives you 100,000 IDR; one ha with jungle rubber gives you 50,000 IDR.

Experimenter points at respective cells.

Which production system gives the higher earnings per ha? The earnings from one ha planted with oil palm are higher than the earnings generated from one ha cultivated with jungle rubber. Suppose that you own 10 ha: One ha planted with oil palm gives you 100,000 IDR. One ha planted with jungle rubber gives you 60,000 IDR. Which production system generates the higher earning per ha? Like for the 5 ha farmers, the earnings from one ha planted with oil palm are higher than the earnings generated from one ha cultivated with jungle rubber. Now, let us compare the earnings for farmers with 5 ha with the earnings of farmers with 10 ha: For oil palm, both farmers with 5 and 10 ha receive 100,000 IDR. Are the earnings per ha oil palm the same for 5 and 10 ha farmers? Yes! Are they also the same for jungle rubber? Let's take a look. Farmers with 5 ha receive 50,000 IDR from one ha planted with jungle rubber. Farmers with 10 ha receive 60,000 IDR from one ha planted with jungle rubber. So farmers with 5 ha receive less from one ha planted with jungle rubber than farmers with 10 ha. Experimenter points at respective cells. 
As I have already mentioned, your earnings do not only depend on your decision on how many ha you plant with oil palm and jungle rubber respectively, it also depends on the decision of your group members (the other two participants in your group). These earnings are depicted in this column. Experimenter point at respective column. One ha that you plant with jungle rubber, gives your two group members 20,000 IDR. And the other way around, one ha planted by your group members gives you 20,000 IDR. Let's make an example: Suppose we (Experimenter randomly selects two others) are in one group. Of course, in the experiment you won't know the other two group members. Let's assume I plant one ha of jungle rubber, he/she receives 20,000 IDR each. It indicates that I can influence the earnings of my two group members. And the other way around, let's assume, he /she plants one ha jungle rubber I receive 20,000 IDR. It means that my earnings are affected by the decision of my group members.

If you have any questions, please ask. We will play together a number of decisions. In each decision we will change the earnings. In each decision, you decide how many ha you want to plant with oil palm and how many ha you want to plant with jungle rubber. Due to the fact that the numbers change from decision to decision, please make your decision very carefully.

\subsection{How to make decisions?}

As I mentioned before, in this brown envelope you can find stickers, the number of ha that you own in this workshop. For each decision you will receive a new envelope with the same amount of stickers as in the previous decision. In addition you will find this decision card, with a picture of an oil palm plantation and jungle rubber plot. Experimenter show small decision card. A large decision card is displayed on the white board. On this decision card you make your decisions on how many ha you want to plant with oil palm and how many ha you want to plant with jungle rubber.

Let's make an example (1). The example is done on the white board with green dots, representing the stickers. Suppose that you receive a brown envelope with 5 ha, (represented by 5 stickers) Experimenter holds up the green dots and you decide to plant 3 ha with oil palm. You stick 3 stickers here, where you can see the picture of an oil palm plantation. Experimenter sticks the green dots on the white board. Now, you have planted 3 ha with oil palm plantation. In this example you intend to plant 2 ha with jungle rubber. Therefore you stick the stickers here, where you can see the picture of a jungle rubber plot. Experimenter sticks the green dots on the white board. What have you planted? Experimenter counts the green dots. Now 
you have planted 3 ha oil palm plantation and 2 ha jungle rubber plot. All ha (stickers) have to be used in one decision round.

Experimenter shows two alternative combinations of oil palm and jungle rubber by switching the green dots on the white board (1 oil palm/4 jungle rubber, 4 oil palm/1 jungle rubber).

All possible combination should be considered in your decision process (Also 5/0; 0/5). Let's make a second example (2): Again, the experimenter does the example on a white board (decision card for 10 ha farmers). Suppose that you receive a brown envelope with 10 ha, indicating that you own 10 ha in each decision round. Assuming that you decide to plant 4 ha with oil palm plantation, you stick 4 stickers here where you can see the picture of oil palm plantation. Experimenter sticks the stickers on the white board. Now you have planted 4 ha with oil palm plantation. On the remaining 6 ha you decide to cultivate jungle rubber. You stick 6 stickers, where you can see the picture of a jungle rubber plot.

Experimenter sticks the stickers on the white board. Experimenter shows two alternative combinations of oil palm and jungle rubber by switching the green dots on the white board (8/2; 2/8).

All possible combination should be considered in your decision process (Also 10/0;0/10).

\subsection{What would have you earned in these two examples?}

\section{Example 1:}

Experimenter has both the earning table and the decision cards from the previous examples on the white board.

The calculation is written on a large blank paper on the white board. In the first example, you had 5 ha of land. You planted 3 ha with oil palm and 2 ha with jungle rubber.

\section{Experimenter shows on white board.}

Where do you have to look up the earnings for 5 ha farmers? This row.

Experimenter points at respective row. 
One ha planted with oil palm gives you 100,000 IDR. Experimenter shows respective cell. Since you decided in this example to plant 3 ha with oil palm, the earnings from oil palm are $3 * 100,000$ IDR $=300,000$ IDR.

In addition, we assumed that you decided to plant 2 ha with jungle rubber. One ha gives you 50,000 IDR. You earned from jungle rubber $2 * 50,000$ IDR $=100,000$ IDR. The calculation is written on white board. Are we already done with the whole calculation of your earning? No, the earnings generated due to the cultivation of jungle rubber by the group members have to be calculated. In addition, each ha that your two group members plant with jungle rubber, gives you 20,000 IDR.

Experimenter shows on white board.

Let's suppose that your group members planted together 6 ha of jungle rubber. You earned $6 * 20,000$ IDR=120,00 IDR. In this example you earned in total 520,000 IDR. Amounts are summed up by experimenter. At the end of the session one decision is randomly drawn, $10 \%$ of the earnings are given to you in a closed envelope. Since the envelopes are closed, none of the other workshop members receive information on how much the others have earned in this workshop. $10 \%$ of 520,000 IDR are 52,000 IDR.

Experimenter writes down the calculation on white board. Experimenter shows a voucher, containing the information on the amount of earnings (52,000 IDR).

\section{Example 2:}

In this example you own 10 ha. You decided to plant 4 ha with oil palm and 6 ha with jungle rubber.

Experimenter shows on white board.

Since you owned 10 ha, we have to look the earnings up here.

Experimenter points at respective cell.

What have you earned in this decision round? How much do you earn from one ha cultivated with oil palm? 
Calculation is written on white board by experimenter.

One ha planted with oil palm gives you 100,000 IDR. In this example, you plant 4 ha with oil palm plantation. The earnings from oil palm are $4 * 100,000$ IDR $=400,000$ IDR. You planted 6 ha with jungle rubber. How much do you earn from one ha cultivated with jungle rubber? One ha planted with jungle rubber gives you 60,000 IDR. You earned from jungle rubber $6 * 60,000$ IDR=360,000 IDR. Are we already done with the calculation of the earnings? No!

In addition, each ha that your group members plant with jungle rubber gives you 20,000 IDR. Let's suppose that your other two group members planted in total 6 ha with jungle rubber. You earned $6{ }^{*} 20,000$ IDR $=120,000$ IDR. In this example, you earned in total 880,000 IDR $* 10 \%=88,000$ IDR. You do not need to worry that you have to calculate your earnings by yourself. The earnings will be calculated by the team of enumerators. Nevertheless, for your decision making process it is quite important that you listen carefully to the explanations of the earning tables.

Do you have any questions so far? Then, it is time that you make your decision by yourself. Before we start with the actual decisions, we play two decisions. The earnings of those two decisions won't be paid out to you. It more that you get used to the whole procedure. The earnings we state here are for the next two decisions only hypothetical, afterwards we will play the actual decisions, where you can earn money. The enumerators assist you.

\section{Hypothetical decisions}

Communication of any kind is not allowed. Please make your private decisions now, each of you choose one of these brown envelopes and keep it closed in front of you. Participant choose brown envelope. Please open your envelope. Please fix this ID card on your cloth. Experimenter shows how to fix ID card. Enumerators assist participants. In the envelope you can find either 5 or 10 stickers, indicating the number of ha you own in each decision and the decision card. Before you make your decision, I will explain the earning table to you.

\section{Decision 1 (base scenario, no PES):}

Experimenter uses the earning table displayed on white board to explain the earnings. 
Suppose that you own 5 ha: One ha planted with oil palm gives you 100,000 IDR, one ha with jungle rubber gives you 50,000 IDR. Experimenter points at respective cells. Suppose that you own 10 ha: One ha planted with oil palm gives you 100,000 IDR. One ha planted with jungle rubber gives you 60,000 IDR. Which production system generates higher earnings per ha? The earnings from one ha planted with oil palm are higher than the earnings generated from one ha cultivated with jungle rubber. Now, let us compare the earnings for farmers with 5 ha with the earnings of farmers with 10 ha: For oil palm, both farmers with 5 and 10 ha receive 100,000 IDR. Are the earnings per ha jungle rubber the same for 5 and 10 ha farmers? No! Farmers with 5 ha receive 50,000 IDR from one ha planted with jungle rubber. Farmers with 10 ha receive 60,000 IDR from one ha planted with jungle rubber. Hence, farmers with 5 ha receive less from one ha planted with jungle rubber than farmers with 10 ha.

Experimenter points at respective cells.

Are we already done with the explanation of the earning table? No! One ha that you plant with jungle rubber gives your two group members 20,000 IDR. And the other way around, one ha planted by your group members gives you 20,000 IDR. Remember, now we play only hypothetically, so this money is not paid out to you. Please make you decision on how many ha you plant with oil palm and jungle rubber, respectively by sticking our stickers on the respective areas of the decision card. The enumerators assist you. When you have done your decisions and no stickers are left, please put your decision card back into the brown envelope.

Now we play a second decision round. You will receive a white envelope, where you can find the same amount of stickers, as in the previous decision round and again the decision card. Since some numbers in the earning table will change, we will go again through the earning table. Please listen carefully. After the explanation, you are allowed to make your decision. Enumerators distribute white envelopes.

\section{Decisions 2 with monetary incentive for jungle rubber}

From here on, the explanations differ according to the treatments.

Treatments:

1. Individual PES scheme, where incentive is explicitly framed as Payments for Environmental Services.

2. Collective PES scheme, where incentive is explicitly framed as Payments for Environmental Services and it is conditional to certain threshold. 
The following section presents the instruction per treatment.

Treatment 1. Individual PES scheme, where incentive is explicitly framed as Payments for Environmental Services.

What is different in this decision round? We would like to introduce Payments for Environmental Services (PES)-like a bonus for the cultivation of jungle rubber (you do not receive this bonus for the cultivation of oil palm). As we mentioned before, jungle rubber cultivation compared to oil palm has a positive impact on the environment: soil is healthier, more water is available and the number of birds and mammals increases. Therefore, we would like to foster pro-environmental behavior by paying extra amount of earning for the cultivation of jungle rubber.

Experimenter changes the earning table by sticking an additional row for the Payments for environmental services on the white board.

Let's go through the earning table together: Suppose that you own 5 ha. One ha planted with oil palm gives you 100,000 IDR, one ha with jungle rubber gives you 50,000 IDR. Here, you can see the bonus for the cultivation of jungle rubber. For each ha cultivated with jungle rubber, we give you a PES of 20,000 IDR, since jungle rubber cultivation is positive for the environment. In total, you earn per ha cultivated with jungle rubber 70,000 IDR.

Experimenter points at respective cells.

Which production system generates higher earning per ha? The earnings from one ha planted with oil palm are higher than the earnings generated from one ha cultivated with jungle rubber. Suppose that you own 10 ha. One ha planted with oil palm gives you 100,000 IDR. One ha planted with jungle rubber gives you 60,000 IDR. Here you can see the bonus for the cultivation of jungle rubber. For each ha cultivated with jungle rubber, we give you a PES of 20,000 IDR, since jungle rubber cultivation is positive for the environment. In total, you earn per ha cultivated with jungle rubber 80,000 IDR. Which production system generates higher earnings per ha? The earnings from one ha planted with oil palm are higher than the earnings generated from one ha cultivated with jungle rubber. 
Let's compare the bonus of 5 and 10 ha farmers. Both 5 and 10 ha farmers receive the same amount of bonus per ha jungle rubber. It indicates that, even with bonus, 10 ha farmers earn more $(80,000$ IDR) per ha than 5 ha farmers. They earn only 70,000 IDR per ha jungle rubber. In addition, one ha that you plant with jungle rubber gives your two group members 20,000 IDR. And the other way around, one ha planted by your group members gives you 20,000 IDR. Remember this only a hypothetical decisions, so the money you earn in this round in not paid out to you.

Please make you decision on how many ha you plant with oil palm and jungle rubber, respectively by sticking our stickers on the respective areas of the decision card. The enumerators assist you. When you have done your decisions and no stickers are left, please put your decision card back into the white envelope.

We have played decisions. As you have recognized, we change the earnings between the decision rounds. Therefore it is quite essential that you make your decision very carefully. All combinations of oil palm /jungle rubber are possible and reasonable. Now, we going to make the actual decisions. Now, it is not hypothetically any more. Your decisions in the upcoming decisions determine the amount that you gain in this workshop.

Treatment 2. Collective PES scheme (where incentive is explicitly framed as Payments for Environmental Services and it is conditional to certain threshold)

What is different in this decision round? We would like to introduce Payments for Environmental Services (PES)-like a bonus for the cultivation of jungle rubber (you do not receive this bonus for the cultivation of oil palm). As we mentioned before, jungle rubber cultivation compared to oil palm has a positive impact on the environment: soil is healthier, more water is available and the number of birds and mammals increases. Therefore, we would like to foster pro-environmental behavior by paying extra amount of earning for the cultivation of jungle rubber but this extra amount is subject to a minimum number of hectares of jungle rubber that you and your two group members cultivate with jungle rubber. The minimum number of hectares with jungle rubber that the group have to achieve is 7 has. Remember, communication of any kind is not allowed. Before you make your decision, I will explain the earning table to you. 
Experimenter changes the earning table by sticking an additional row for the Payments for environmental services on the white board.

Let's go through the earning table together: Suppose that you own 5 ha. One ha planted with oil palm gives you 100,000 IDR, one ha with jungle rubber gives you 50,000 IDR. Here, you can see the bonus for the cultivation of jungle rubber. For each ha cultivated with jungle rubber, we give you a PES of 20,000 IDR if the total group cultivates 7 has, since jungle rubber cultivation is positive for the environment. If the group achieves the 7 has, then you earn per ha cultivated with jungle rubber is 70,000 IDR, otherwise you earning remains at 50,000 IDR.

Experimenter points at respective cells.

Which production system generates higher earning per ha? The earnings from one ha planted with oil palm are higher than the earnings generated from one ha cultivated with jungle rubber. Suppose that you own 10 ha. One ha planted with oil palm gives you 100,000 IDR. One ha planted with jungle rubber gives you 60,000 IDR. Here you can see the bonus for the cultivation of jungle rubber. For each ha cultivated with jungle rubber, we give you a PES of 20,000 IDR if you and your two group members achieve the 7 has of jungle rubber since its cultivation is positive for the environment. In total, you earn per ha cultivated with jungle rubber 80,000 IDR if the 7 has are achieved otherwise you earning remain at 60,000 . Which production system generates higher earnings per ha? The earnings from one ha planted with oil palm are higher than the earnings generated from one ha cultivated with jungle rubber.

Let's compare the bonus of 5 and 10 ha farmers. Both 5 and 10 ha farmers receive the same amount of bonus per ha jungle rubber. It indicates that, even with bonus, 10 ha farmers earn more (80,000 IDR) per ha than 5 ha farmers. They earn only 70,000 IDR per ha jungle rubber. In addition, one ha that you plant with jungle rubber gives your two group members 20,000 IDR. And the other way around, one ha planted by your group members gives you 20,000 IDR. Remember this only a hypothetical decisions, so the money you earn in this round in not paid out to you.

Please make you decision on how many ha you plant with oil palm and jungle rubber, respectively by sticking our stickers on the respective areas of the decision card. The enumerators assist you. When you have done your decisions and no stickers are left, please put your decision card back into the white envelope. 
We have played decisions. As you have recognized, we change the earnings between the decision rounds. Therefore it is quite essential that you make your decision very carefully. All combinations of oil palm /jungle rubber are possible and reasonable. Now, we going to make the actual decisions. Now, it is not hypothetically any more. Your decisions in the upcoming decisions determine the amount that you gain in this workshop.

\section{Non-hypothetical setting}

Communication of any kind is still not allowed. Please make your private decisions. Now, each of you choose one of these brown envelopes and keep it closed in front of you. Participant choose brown envelope. Please open your envelope. Please fix this ID card on your cloth. Experimenter shows how to fix ID card. Enumerators assist participants. In the envelope you can find either 5 or 10 stickers, indicating the number of ha you own in each decision and the decision card. Before you make your decision, I will go again through the earning table. It is very essential that you listen very carefully.

\section{Round 1 (base scenario, no PES)}

Experimenter uses the earning table displayed on white board to explain the earnings.

Suppose that you own 5 ha: One ha planted with oil palm gives you 100,000 IDR, one ha with jungle rubber gives you 50,000 IDR. Experimenter points at respective cells. Suppose that you own 10 ha: One ha planted with oil palm gives you 100,000 IDR. One ha planted with jungle rubber gives you 60,000 IDR. Again, the earning for jungle rubber is lower than for oil palm. Are the earnings per ha jungle rubber the same for 5 and 10 ha farmers? No! Farmers with 5 ha receive less from one ha planted with jungle rubber than farmers with 10 ha.

\section{Experimenter points at respective cells.}

Please consider, furthermore that one ha that you plant with jungle rubber gives your two group members 20,000 IDR. And the other way around, one ha planted by your group members gives you 20,000 IDR. Please make you decision on how many ha you plant with oil palm and jungle rubber, respectively by sticking our stickers on the respective areas of the decision card. The enumerators assist you. When you have done your decisions and no stickers are left, please put your decision card back into the brown envelope. Now we play a second decision round. You will receive a white envelope, where you can find the same amount of stickers, as in the previous decision round and again the decision card. Since some 
numbers in the earning table will change, we will go again through the earning table. Please listen carefully. After the explanation, you are allowed to make your decision.

Enumerators distribute white envelopes.

\section{Round 2 and 3 with monetary incentive for jungle rubber (the incentive could be low}

\section{or high)}

From here on, the explanations differ according to the treatments.

Treatments:

- Individual PES scheme, where incentive is explicitly framed as Payments for Environmental Services.

- Collective PES scheme, where incentive is explicitly framed as Payments for Environmental Services and it is conditional to certain threshold.

Treatment 1. Individual PES scheme, where incentive is explicitly framed as Payments for Environmental Services.

What is different in this decision round? We would like to introduce Payments for Environmental Services (PES)-like a bonus for the cultivation of jungle rubber (you do not receive this bonus for the cultivation of oil palm). As we mentioned before, jungle rubber cultivation compared to oil palm has a positive impact on the environment: soil is healthier, more water is available and the number of birds and mammals increases. Therefore, we would like to foster pro-environmental behavior by paying extra amount of earning for the cultivation of jungle rubber. Experimenter changes the earning table by sticking an additional row for the Payments for environmental services on the white board.

Let's go through the earning table together: Suppose that you own 5 ha. One ha planted with oil palm gives you 100,000 IDR, one ha with jungle rubber gives you 50,000 IDR. Here, you can see the bonus for the cultivation of jungle rubber. For each ha cultivated with jungle rubber, we give you a PES of $X$ IDR, since jungle rubber cultivation is positive for the environment. In total, you earn per ha cultivated with jungle rubber $X I D R$.

Experimenter points at respective cells.

Which production system generates higher earning per ha? The earnings from one ha planted with oil palm are higher than the earnings generated from one ha cultivated with jungle rubber. Suppose that you own 10 ha. Oneha planted with oil palm gives you 100,000 IDR. One ha 
planted with jungle rubber gives you 60,000 IDR. Here you can see the bonus for the cultivation of jungle rubber.

For each ha cultivated with jungle rubber, we give you a PES of $X I D R$, since jungle rubber cultivation is positive for the environment. In total, you earn per ha cultivated with jungle rubber $X$ IDR. Which production system generates higher earnings per ha? The earnings from one ha planted with oil palm are higher than the earnings generated from one ha cultivated with jungle rubber.

Let's compare the bonus of 5 and 10 ha farmers. Both 5 and 10 ha farmers receive the same amount of bonus per ha jungle rubber. It indicates that, even with bonus, 10 ha farmers earn more per ha than 5 ha farmers. They earn only $X$ IDR per ha jungle rubber. In addition, as always one ha that you plant with jungle rubber gives your two group members 20,000 IDR. And the other way around, one ha planted by your group members gives you 20,000 IDR.

Please make you decision on how many ha you plant with oil palm and jungle rubber, respectively by sticking our stickers on the respective areas of the decision card. The enumerators assist you. When you have done your decisions and no stickers are left, please put your decision card back into the white envelope.

Treatment 2. Collective PES scheme (where incentive is explicitly framed as Payments for Environmental Services and it is conditional to certain threshold)

What is different in this decision round? We would like to introduce Payments for Environmental Services (PES)-like a bonus for the cultivation of jungle rubber (you do not receive this bonus for the cultivation of oil palm) but at considering you and your two group members contribution. As we mentioned before, jungle rubber cultivation compared to oil palm has a positive impact on the environment: soil is healthier, more water is available and the number of birds and mammals increases. Therefore, we would like to foster pro-environmental behavior by paying extra amount of earning for the cultivation of jungle rubber but you and your two group members have to achieve a minimum of 7 has in order to receive this extra payment. Experimenter changes the earning table by sticking an additional row for the Payments for environmental services on the white board with the caveat of 7 has as minimum number of has on jungle rubber.

Let's go through the earning table together: Suppose that you own 5 ha. One ha planted with oil palm gives you 100,000 IDR, one ha with jungle rubber gives you 50,000 IDR. Here, you 
can see the bonus for the cultivation of jungle rubber. For each ha cultivated with jungle rubber, we give you a PES of X IDR if you and your two group members achieve 7 has of jungle rubber as its cultivation is positive for the environment. In total, you earn per ha cultivated with jungle rubber $X I D R$ if 7 has are achieved, otherwise your earnings reaming of 50,000 IDR.

Experimenter points at respective cells.

Which production system generates higher earning per ha? The earnings from one ha planted with oil palm are higher than the earnings generated from one ha cultivated with jungle rubber. Suppose that you own 10 ha. One ha planted with oil palm gives you 100,000 IDR. One ha planted with jungle rubber gives you 60,000 IDR. Here you can see the bonus for the cultivation of jungle rubber.

For each ha cultivated with jungle rubber, we give you a PES of $X I D R$, since jungle rubber cultivation is positive for the environment if the group achieves 7 has of jungle rubber as minimum. In total, you earn per ha cultivated with jungle rubber X IDR if the 7 has are achieved, otherwise your earning are of 60,000 IDR. Which production system generates higher earnings per ha? The earnings from one ha planted with oil palm are higher than the earnings generated from one ha cultivated with jungle rubber.

Let's compare the bonus of 5 and 10 ha farmers. Both 5 and 10 ha farmers receive the same amount of bonus per ha jungle rubber. It indicates that, even with bonus, 10 ha farmers earn more per ha than 5 ha farmers. They earn only X IDR per ha jungle rubber if the contribution at the group level is 7 or more. In addition, as always one ha that you plant with jungle rubber gives your two group members 20,000 IDR. And the other way around, one ha planted by your group members gives you 20,000 IDR.

Please make you decision on how many ha you plant with oil palm and jungle rubber, respectively by sticking our stickers on the respective areas of the decision card. The enumerators assist you. When you have done your decisions and no stickers are left, please put your decision card back into the white envelope.

Thank you very much for your participation. Now we would like to continue with a short post experimental survey. The interviews will be done individually. Since we cannot conduct all questionnaire parallel, we ask some of you to wait until they are picked up 
by the enumerators. Please help yourself with the refreshers. Now you are also allowed to communicate, but we kindly ask you not to talk with your neighbors about the game until the workshop is over. In the meantime your earning that you gained in this workshop will be calculated. 


\section{Appendix 5. Post Experimental Survey - Indonesia}

Q1. ID :

Q2. Workshop ID :

Q3. Treatment :

Q4. Date of workshop

Q5. Full name of Respondent

120

Q6. Interviewer

Q7. Interviewer's

signature:

We kindly ask you to answer some questions regarding the decisions you have recently made. Please tick the appropriate answer.

Q8. In this workshop you earned some money. The amount of money that you earned in this workshop depends on:

Only on your production decision in this workshop

On your production decision and the production decision of your group members

Neither on your production decision, nor on the production decision of your group members. It was not possible for you or your group members to influence the amount of money.

Q 9. In the decisions, all participants had the same amount of available land.

$\square$ Yes $\square$ No

$Q$ 10. The earnings from oil palm (per hectare) were higher than the earnings from rubber agroforestry (per hectare)

Yes $\quad \square$ No

$Q$ 11. The earnings per hectare rubber agroforestry were different for participants with 5 hectare and those with 10 ha.

Yes No

$Q$ 12. The introduction of Payments for environmental services aimed to foster rubber agroforestry cultivation.

Yes

No

$Q$ 13.The amount of Payments for Environmental services per hectare rubber agroforestry was different for participants with 5 hectare and those with 10 hectare. .

$\square$ Yes $\square$ No

Q 14. What do you think was the objective of this workshop?

\begin{tabular}{|l|c|c|c|c|}
\hline & $\begin{array}{c}\text { Strongly } \\
\text { Agree }\end{array}$ & Agree & Disagree & $\begin{array}{c}\text { Strongly } \\
\text { Disagree }\end{array}$ \\
\hline $\begin{array}{l}\text { Q 15. I feel satisfied with the earning I received } \\
\text { in this workshop. }\end{array}$ & & & \\
\hline
\end{tabular}


Q 16. I had the feeling that I could influence the amount of earning that $\mathrm{I}$ receive in this workshop.

$Q$ 17. I had the feeling that the amount of earning was just a matter of luck.

$Q$ 18. I had the feeling that the other group

members mainly behave fair in this game.

In the workshop you decided how many hectares you plant with oil palm and how many hectares you plant with rubber agroforestry. Please indicate below your main reasons for your personal decision. Please indicate how strongly you feel about each reason. If the respective reason does not hold four you, please tick irrelevant.

Q 19. Did you cultivate any oil palm in this workshop?

$\square$ Yes No

If the respondent did not cultivate oil palm, please switch to Q24

\begin{tabular}{|l|l|l|l|l}
\hline In this workshop, I planted & Very strongly & Strongly & Moderate & Irrelevan
\end{tabular}

oil palm $20 \ldots$ because it

generates the highest

earnings for me.

Q 21......because I did not want that my group members benefit from my decision and receive the externality.

Q 22.....because I did not want that my group member with 10 hectare benefits from my decision and receive the externality

Q 23. Was there any other reason for you to plant oil palm in this workshop? 1.

2.

3.

Q 24.Did you cultivate rubber agroforestry in this workshop?

\begin{tabular}{|l|l}
\hline Yes the respondent did not cultivate oil palm, please switch to \\
\hline If the
\end{tabular}

In this workshop, I planted
oil palm

Q 25....because I wanted

that my group members

\begin{tabular}{|l|c|c|c|}
\hline Very strongly & Strongly & Moderate & Irrelevant \\
& & & \\
\hline
\end{tabular}




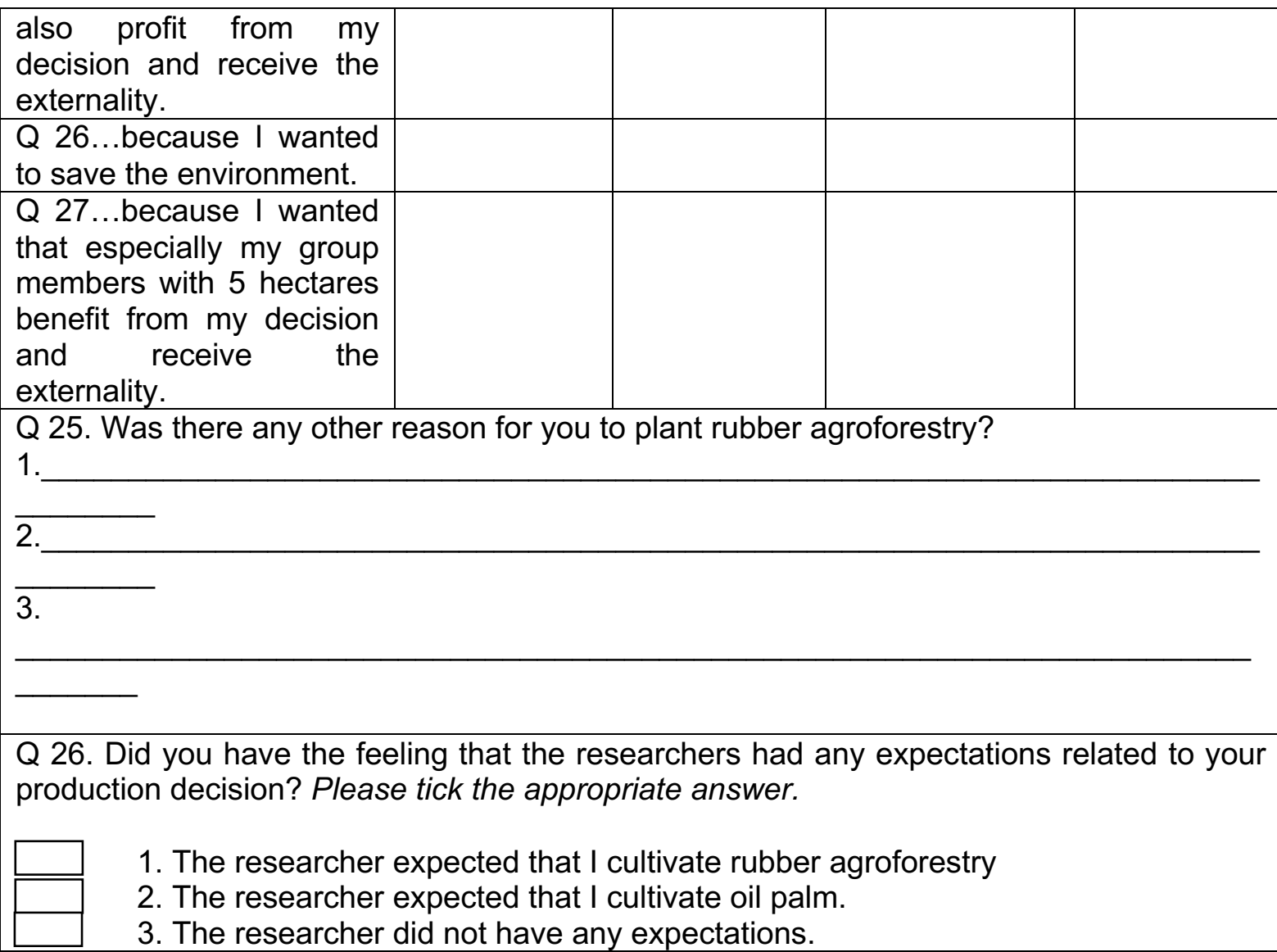

Q 27. If $Q 26.1$. or $Q 26.2$. ticked, in how far did these expectations influence your decision?

\begin{tabular}{|l|l|l|l|}
\hline Very strong & Strong & Moderate & Not at all \\
\hline & & & \\
\hline
\end{tabular}

Q 28. Did you own 5 or 10 hectares in this workshop?

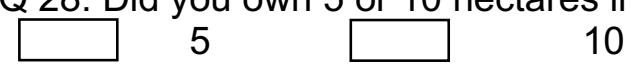

\section{If respondent owned 10 ha, go to Q37.}

You owned 5 ha in each decision round. Now, we present some feelings you might have had in this workshop with respect to the fact that you had 5 ha. Please indicate how strong you feel about each aspect.

\begin{tabular}{|l|l|l|l|l|}
\hline $\begin{array}{l}\text { Q 29. I had the feeling that it was absolutely } \\
\text { random, that I had 5 hectares in this } \\
\text { workshop. }\end{array}$ & $\begin{array}{c}\text { Very } \\
\text { strong }\end{array}$ & Strong & Moderate & $\begin{array}{c}\text { Not at } \\
\text { all }\end{array}$ \\
\hline $\begin{array}{l}\text { Q 30. I had the feeling of injustice that I had } \\
5 \text { hectares in this workshop. }\end{array}$ & & & & \\
\hline $\begin{array}{l}\text { Q 31. I think participants with 10 hectares } \\
\text { had feelings of injustice. }\end{array}$ & & & & \\
\hline $\begin{array}{l}\text { Q 32. I had the feeling that I had the same } \\
\text { possibilities in this workshop as participants } \\
\text { with 10ha. }\end{array}$ & & & & \\
\hline
\end{tabular}




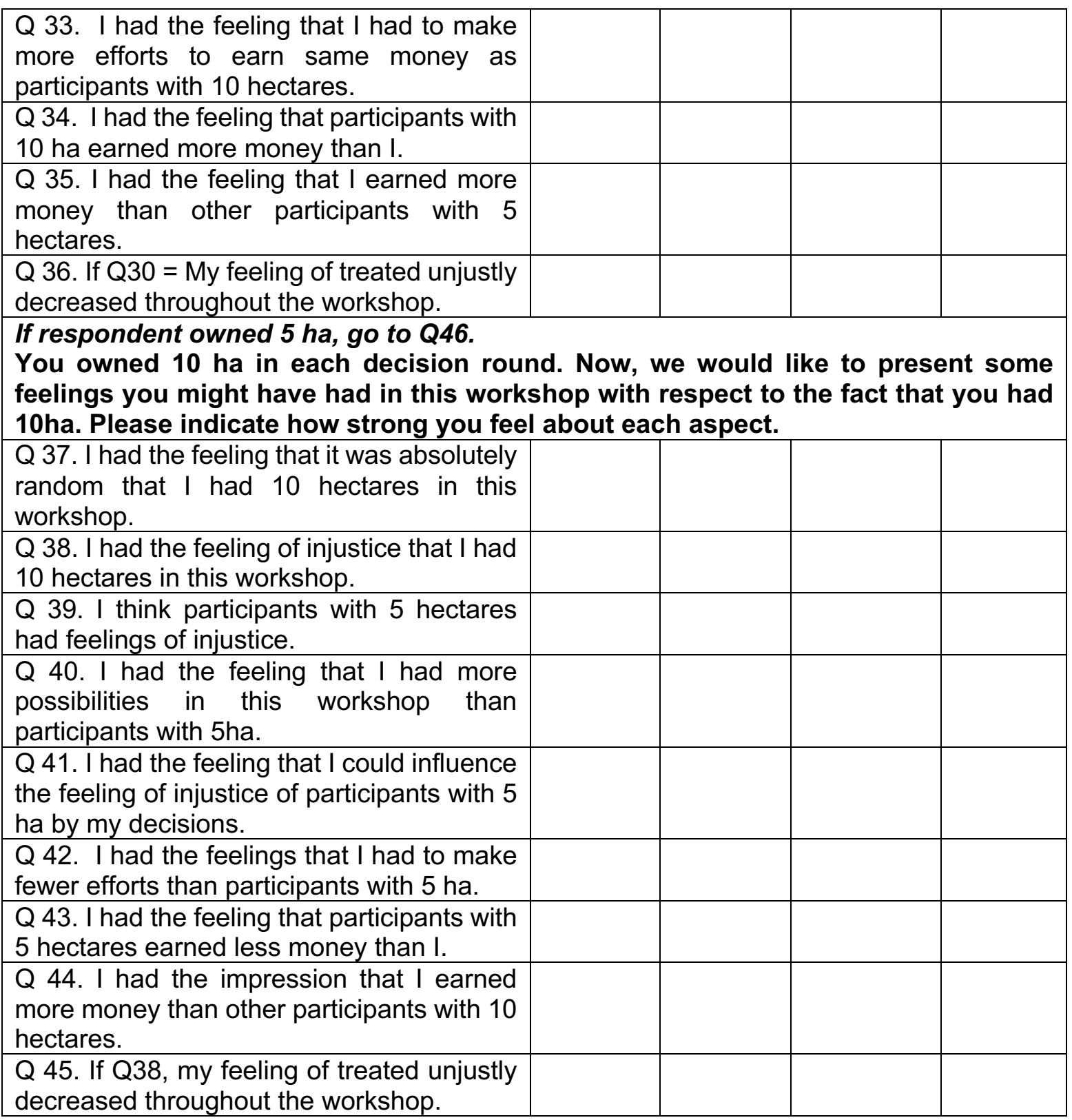

\begin{tabular}{|c|c|c|c|c|}
\hline $\begin{array}{l}\text { decision round } 2 \text { and } 3 \text {, we introduced } P \\
\text { cultivation of rubber agroforestry. Now } \\
\text { you might have had with respect to the } b \\
\text { about each aspect. }\end{array}$ & $\begin{array}{l}\text { nent } \\
\text { wou } \\
\text { is. P }\end{array}$ & $\begin{array}{l}\text { viro } \\
\text { to i } \\
\text { ndic }\end{array}$ & $\begin{array}{l}\text { tal serv } \\
\text { uce sor } \\
\text { ow stro }\end{array}$ & $\begin{array}{l}\text { for the } \\
\text { elings } \\
\text { ou feel }\end{array}$ \\
\hline & $\begin{array}{c}\text { Very } \\
\text { strong }\end{array}$ & Strong & Moderate & $\begin{array}{l}\text { Not at } \\
\text { all }\end{array}$ \\
\hline $\begin{array}{l}\text { Q 46. I had the feeling that the bonus for the } \\
\text { planting of jungle rubber privileged } \\
\text { participants with } 5 \text { hectares. }\end{array}$ & & & & \\
\hline $\begin{array}{l}\text { Q } 47 . \text { I had the feeling that the bonus for } \\
\text { planting jungle rubber privileged } \\
\text { participants with } 10 \text { hectares. }\end{array}$ & & & & \\
\hline $\begin{array}{l}\text { Q 48. I had the feeling that the bonus } \\
\text { improved my situation in this workshop. }\end{array}$ & & & & \\
\hline
\end{tabular}




\begin{tabular}{|l|l|l|l|l|}
\hline $\begin{array}{l}\text { Q 49. I had the feeling that the bonus was } \\
\text { unfair. }\end{array}$ & & \\
\hline $\begin{array}{l}\text { When you look back at your life, which statements apply to your experience in lief } \\
\text { and your person? } \\
\text { Please indicate how strong you agree or disagree with the statement. }\end{array}$ \\
\hline $\begin{array}{l}\text { Q 50. I have experienced injustice often. } \\
\text { Q 51. My family has experienced injustice } \\
\text { often. }\end{array}$ & $\begin{array}{c}\text { Strongly Agree } \\
\text { agree }\end{array}$ & & Disagree & $\begin{array}{l}\text { Strongly } \\
\text { disagree }\end{array}$ \\
\hline Q 52. I have observed injustice often. & & & & \\
\hline $\begin{array}{l}\text { Q 53. When I meet other people, I am } \\
\text { concerned about their expectations about } \\
\text { me. }\end{array}$ & & & & \\
\hline $\begin{array}{l}\text { Q 54. I try to act like others to be consistent } \\
\text { with social norms. }\end{array}$ & & & & \\
\hline $\begin{array}{l}\text { Q 55. I would not complain publicity even } \\
\text { when I have been treated unfairly. }\end{array}$ & & & & \\
\hline $\begin{array}{l}\text { Q } 56 . \text { When I have been treated unfairly, I } \\
\text { will try to punish others' behavior. }\end{array}$ & & & & \\
\hline $\begin{array}{l}\text { Q 57. When I have been treated unfairly, I } \\
\text { will try to punish others' behavior even if I } \\
\text { lose money. }\end{array}$ & & & & \\
\hline
\end{tabular}

\begin{tabular}{|l|l|l|l|l|}
\hline & $\begin{array}{c}\text { Very } \\
\text { interesting }\end{array}$ & Interesting & Uninteresting & $\begin{array}{c}\text { Very } \\
\text { uninteresting }\end{array}$ \\
\hline $\begin{array}{l}\text { Q 58. How interesting did you find } \\
\text { this workshop? }\end{array}$ & & & & \\
\hline & & & & \\
\hline $\begin{array}{l}\text { Q 59. I received sufficient } \\
\text { information on the procedure of } \\
\text { this workshop. }\end{array}$ & & Agree & Disagree & $\begin{array}{l}\text { Strongly } \\
\text { disagree }\end{array}$ \\
\hline
\end{tabular}

Q 60. What is fairness for you?

\begin{tabular}{|l|l|}
\hline Q 61. How many workshop participants are members of your & extended family? \\
\hline Q 62. How many workshop participants do you know by name? & $\#$ \\
\hline $\begin{array}{l}\text { Q 63. How many workshop participants do you speak to at least } \\
\text { once per month? }\end{array}$ & $\#$ \\
\hline
\end{tabular}

Q 64. Nick name

Q 65. Name of your father

Q 66. Name of your firstborn

$\mathrm{Q}$ 66. Mobile phone number 


\section{Thanks for your participation. Appendix 6. General Household Survey - Indonesia}

We are researchers from the EFFORT project. It is a collaboration of the University of Goettingen, Germany, the Universitas Pertanian Bogor and the Universitas Jambi. We would like to better understand the decision farmers make in Jambi Province. If you agree to participate in this study you will be asked to answer some questions. You will be asked some questions about yourself and your family members, your farming activities and your housing and assets. The interview will take about 1 hour. You are free to ask at any time. All information collected in this study is confidential and will be used strictly for research purpose. In the last workshop you received an ID number, which will also be used in the analysis of this study. Hence your name will not be used.

\section{Respondent Identification}

\begin{tabular}{|l|l|l|}
\hline QID & Question & Answer \\
\hline 1 & Interviewer (name) & \\
\hline 2 & Respondent (Full name) & \\
\hline 3. & $\begin{array}{l}\text { Is the respondent HHhead? } \\
\text { (1) Yes ; (2) No }\end{array}$ & \\
\hline 3.1 & If QID 1.3=2 HHhead's full name & \\
\hline 4 & Village (name) & \\
\hline 5 & RT (number) & From \\
\hline 6 & Date of interview (mm/dd/20YY) \\
\hline 7 & Time of interview & \\
\hline 8 & Signature of interviewer & \\
\hline
\end{tabular}

\section{Household Identification and socio-demographic characteristics}

\begin{tabular}{|l|l|l|l|}
\hline QID & Question & Answer & Code \\
\hline 1. & $\begin{array}{l}\text { Total number of members staying in the house in the last 12 } \\
\text { months }\end{array}$ & $\#$ \\
\hline 2. & Total number of household members younger than 18 years & & $\#$ \\
\hline 2.1. & If Q2>0: Number of children visiting regularly school? & & $\#$ \\
\hline 3. & $\begin{array}{l}\text { Total number children (younger than 18 years) staying outside } \\
\text { village? }\end{array}$ & $\#$ \\
\hline
\end{tabular}

Please fill in the following table for the RESPONDENT:

\begin{tabular}{|l|l|l|l|l|l|}
\hline QID & 4. & 5. & 6. & 7. & 8. \\
\hline & $\begin{array}{l}\text { Age } \\
\text { (Years) }\end{array}$ & $\begin{array}{l}\text { Marital } \\
\text { status } \\
\text { (Code A) }\end{array}$ & $\begin{array}{l}\text { Duration school } \\
\text { or college } \\
\text { (years) }\end{array}$ & $\begin{array}{l}\text { Last } \\
\text { graduation } \\
\text { (Code B) }\end{array}$ & $\begin{array}{l}\text { Main occupation of } \\
\text { repondent (in the last 12 } \\
\text { month)? (Code C) }\end{array}$ \\
\cline { 5 - 6 } & & Primary Secondary \\
\hline
\end{tabular}




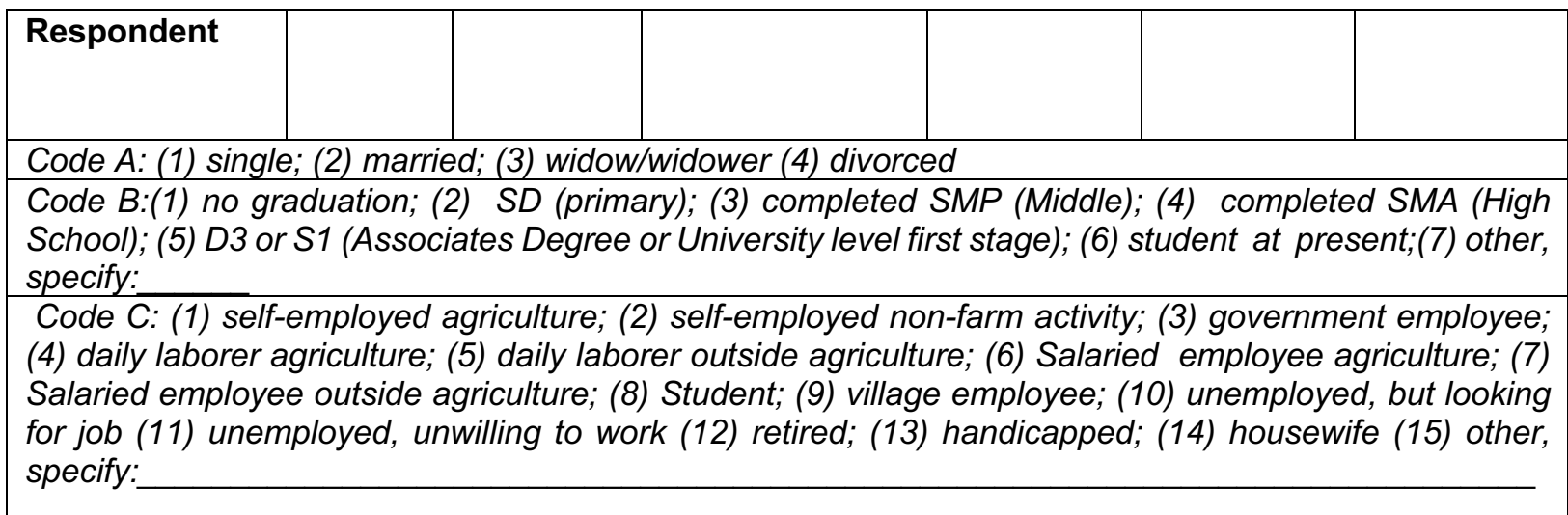

If QID 8=(4) or (6) please continue here

\begin{tabular}{|l|l|l|l|}
\hline QID & Question & Answer & Code \\
\hline 9. & $\begin{array}{l}\text { On what kind of plantation have you mainly (in } \\
\text { terms of income) worked in the last 12 months? }\end{array}$ & $\begin{array}{l}\text { (1)rubber; (2) oil palm; (3) } \\
\text { other: specify: }\end{array}$ \\
\hline
\end{tabular}

\section{Land ownership}

\begin{tabular}{|c|c|c|c|}
\hline QID & Question & Answer & \\
\hline \multirow[t]{2}{*}{1.} & \multirow[t]{2}{*}{$\begin{array}{l}\text { Land owned by the household at the time of } \\
\text { interview (1) Yes; (2) No }\end{array}$} & & $\begin{array}{l}\text { If QID 1.=1 Size of land in } \\
\text { village: }\end{array}$ \\
\hline & & & $\begin{array}{l}\text { If QID 1.=1 Size of land } \\
\text { outside village: } \quad \text { ha }\end{array}$ \\
\hline \multirow[t]{2}{*}{2.} & \multirow[t]{2}{*}{$\begin{array}{l}\text { Land rented by the household at the time of } \\
\text { interview (1) Yes; (2) No }\end{array}$} & & $\begin{array}{l}\text { If QID 2. =1 Size of land in } \\
\text { village: }\end{array}$ \\
\hline & & & $\begin{array}{l}\text { If QID 2.=1 Size of land } \\
\text { outside village: } \quad \text { ha }\end{array}$ \\
\hline 3. & $\begin{array}{l}\text { Total land cultivated by your household } \\
\text { (individually) at the time of interview }\end{array}$ & & Size of land: __ ha \\
\hline 4. & $\begin{array}{l}\text { Do you cultivate any land, owned by others, at the } \\
\text { time of interview? (1) Yes; (2) No }\end{array}$ & & $\begin{array}{lccc}\text { If QID } & \begin{array}{c}4 .=1 \\
\text { ha }\end{array} & \text { Size of } \\
\text { land: } & & \end{array}$ \\
\hline 5. & $\begin{array}{l}\text { Total land cultivated jointly (with inputs and/or } \\
\text { output shared) with other farmers at the time of } \\
\text { interview (1) Yes; (2) No }\end{array}$ & & $\begin{array}{l}\text { If QID } 5 .=1 \text { Size of land: } \\
\text { ha } \\
\text { If for more than one group: } \\
\text { Size of land: } \quad \text { ha }\end{array}$ \\
\hline
\end{tabular}

\section{Cultivation (perennial crops)/fallow land}

\subsection{What kind of perennial crops are you currently cultivating?}

\begin{tabular}{|l|l|l|l|l|}
\hline QID & \multicolumn{1}{|c|}{ Oil palm } & $\begin{array}{l}\text { Rubber } \\
\text { plantation }\end{array}$ & $\begin{array}{l}\text { Jungle } \\
\text { rubber }\end{array}$ \\
\hline 1. & Cultivated area of land (ha) & & & \\
\hline 2. & $\begin{array}{l}\text { Cultivated are of land (under } \\
\text { contract) (ha) }\end{array}$ & & & \\
\hline
\end{tabular}

\begin{tabular}{|l|l|l|}
\hline QID & Area of land (ha) \\
\hline 3. & Fallow land ( land not cultivated for the last 12 months) & \\
\hline
\end{tabular}

\subsection{History of cultivation}

\section{Oil palm}


1. Have you ever cultivated oil palm ?

(if answer: 2 , directly go to 5.2 .)

\begin{tabular}{|l|l|l|}
\hline QID & & Start \\
\hline 2. & With how many hectares did you start cultivation? & \\
\hline 3. & Year & \\
\hline 4. & How did this start happen? Code A & \\
\hline 5. & If QID 4. =1, 3, 8 or 9, What kind of crop was on this area before? Code B & \\
\hline
\end{tabular}

Code A: (: (1) purchasing; (2) selling; (3) converted from/to other crops ; (4) conversion from forest ; (5) obtained as part of a government program (e.g. "trans migransi"); (6) established plantation obtained from company;

(7) inherited ; (8) received as gift ; (9) others: specify:

Code B: (1) oil palm; (2) plantation rubber; (3) jungle rubber; (4) other plantation; (5) annual crops, specify: specify:
(6) grassland
(7 )forest;
(8) bush;
(9) others,

\begin{tabular}{|l|l|l|l|}
\hline QID & Question & Answer & Code \\
\hline 6. & $\begin{array}{l}\text { Have you ever extended the cultivated } \\
\text { oil palm area }\end{array}$ & (1)Yes; (2) No \\
\hline 7. & $\begin{array}{l}\text { If QID6=1; Have you ever converted } \\
\text { from forest to oil palm }\end{array}$ & $\begin{array}{l}\text { (1)Yes;(2) No } \\
\text { If QID7 =1 Total area of } \\
\text { land: ha }\end{array}$ \\
\hline 8. & $\begin{array}{l}\text { If QID6=1 Have you ever converted } \\
\text { from rubber to oil palm }\end{array}$ & $\begin{array}{l}\text { (1)Yes; (2) No } \\
\text { If QID8=1 Total area of land:_ ha }\end{array}$ \\
\hline 9. & $\begin{array}{l}\text { Have you ever reduced the cultivated } \\
\text { oil palm area }\end{array}$ & (1)Yes; (2) No \\
\hline
\end{tabular}

\section{Rubber plantation}

1. Have you ever cultivated rubber monoculture? (if answer:2, directly go to 5.3.)

\begin{tabular}{|c|c|c|}
\hline QID & ( & Start \\
\hline 2. & With how many hectares did you start cultivation? & \\
\hline 3. & Year & \\
\hline 4. & How did this start happen? Code $\mathrm{A}$ & \\
\hline 5. & $\begin{array}{l}\text { If QID } 4=1,3,8 \text { or } 9, \text { what kind of crop was on this area before? } \\
\text { Code B }\end{array}$ & \\
\hline
\end{tabular}

Code A: (: (1) purchasing; (2) selling; (3) converted from/to other crops ; (4) conversion from forest ; (5) obtained as part of a government program (e.g. "trans migrani"); (6) established plantation obtained from company;(7) inherited ; (8) received as gift ; (9) others: specify:

Code B: (1) oil palm; (2) plantation rubber ; (3) jungle rubber ; (4) other plantation ; (5) annual crops, specify:_ _ (6) grassland; $(7$ )forest; (8) bush; (9) others, specify:

\begin{tabular}{|l|l|l|l|}
\hline QID & Question & Answer & Code \\
\hline 6. & $\begin{array}{l}\text { Have you ever extended the cultivated } \\
\text { rubber plantation area }\end{array}$ & $(1)$ Yes; (2) No \\
\hline 7. & $\begin{array}{l}\text { If QID6=1; Have you ever converted } \\
\text { from forest to rubber plantation }\end{array}$ & $\begin{array}{l}(1) \text { Yes;(2) No } \\
\text { If QID7 =1 Total area of land:___ ha }\end{array}$ \\
\hline
\end{tabular}




\begin{tabular}{|l|l|l|}
\hline & & \\
\hline 1. & $\begin{array}{l}\text { Concerning your expenses for food, which of the following is true (reflects most } \\
\text { accurately the situation of your household)? (Code A) }\end{array}$ & \\
\hline 2. & $\begin{array}{l}\text { Concerning your expenses for children's' education, health care, clothing, } \\
\text { housing, which of the following is true (reflects most accurately the situation of } \\
\text { your household)? (Code A) }\end{array}$ & $\begin{array}{l}\text { How much does your household need (not spent!) per month for food (in order } \\
\text { to meet all basic need adequately)? ('000 Rp) }\end{array}$ \\
\hline 3. & $\begin{array}{l}\text { How much does your household need (not spent!) per month for } \\
\text { childrens'education, health care, clothing, housing (in order to meet all basic } \\
\text { need adequately)? ('000 Rp) }\end{array}$ & \\
\hline $\begin{array}{l}\text { Code A : (1) your expenses are below the household's needs(2) Your expenses are on the average } \\
\text { comparable to your household's needs(3) Your expenses exceed your household's needs }\end{array}$ \\
\hline
\end{tabular}

8. Assets

At present how many/much of the following does this household own that are in usable/repairable condition?

\begin{tabular}{|c|c|c|c|}
\hline QID & 1 & 2 & 3. \\
\hline $\begin{array}{l}\text { Asset } \\
\text { (usable/repairabl } \\
\text { e condition) }\end{array}$ & \# owned & Price (purchasing) Rp. ('000 Rp) & $\begin{array}{l}\text { Year (purchasing) (if } \\
\text { HH owns more than } \\
\text { one, ask for year } \\
\text { (purchasing) of oldest) }\end{array}$ \\
\hline $\begin{array}{l}\text { Television } \\
\text { (colour) }\end{array}$ & & & \\
\hline Satellite dish & & & \\
\hline $\begin{array}{l}\text { Television and } \\
\text { satellite dish }\end{array}$ & & & \\
\hline Motor cycle & & & \\
\hline Car & & & \\
\hline $\begin{array}{l}\text { Jeep/Truck/Angk } \\
\text { ot }\end{array}$ & & & \\
\hline Fridge & & & \\
\hline Washing machine & & & \\
\hline $\begin{array}{l}\text { DVD } \\
\text { player/sound } \\
\text { system }\end{array}$ & & & \\
\hline Water pump & & & \\
\hline
\end{tabular}

9. Housing

\begin{tabular}{|l|l|l|l|}
\hline QID & Question & $\begin{array}{l}\text { Respons } \\
\text { e }\end{array}$ & Code \\
\hline 1. & $\begin{array}{l}\text { How would you describe } \\
\text { the dwelling in which your } \\
\text { family currently resides? }\end{array}$ & $\begin{array}{l}\text { (1) wooden house; (2) stone house; (3) other; } \\
\text { specify: }\end{array}$ \\
\hline 2. & $\begin{array}{l}\text { Some people fully own } \\
\text { their dwelling, some still } \\
\text { paying them off, or rent } \\
\text { them or simply live in a } \\
\text { dwelling they do not pay } \\
\text { for. What characterize you } \\
\text { situation? }\end{array}$ & $\begin{array}{l}\text { (1)own; (2)own, with credit; (3)rent; (4) live without } \\
\text { paying anything; (5) other: specify: }\end{array}$ \\
\cline { 2 - 3 } & $\begin{array}{l}\text { How many rooms does } \\
\text { your dwelling have total } \\
\text { number of rooms on } \\
\text { compound if same }\end{array}$ & & \\
\hline
\end{tabular}




\begin{tabular}{|l|l|l|l|}
\hline & $\begin{array}{l}\text { household) please } \\
\text { exclude toilet/bathroom }\end{array}$ & \multicolumn{1}{|c|}{} \\
\hline 4. & Material of roof? & $\begin{array}{l}\text { (1) iron sheet; (2)wood; (3)tiles; (4) other, } \\
\text { specify: }\end{array}$ \\
\hline 5. & $\begin{array}{l}\text { On what does the HH } \\
\text { sleep? }\end{array}$ & $\begin{array}{l}\text { (1)mat (natural material) on the floor; (2) mat (natural } \\
\text { material) above ground; 3)plastic mat on the floor; } \\
\text { (4) plastic mat above ground; (5) mattress on th e } \\
\text { floor; (6) mattress above the ground; (7) foam } \\
\text { mattress on the floor; (8) foam mattress above the } \\
\text { ground; (9) spring bed mattress on the floor; (10) } \\
\text { spring bed mattress above the ground; (11) other, } \\
\text { specify: }\end{array}$ \\
\hline
\end{tabular}

\section{Social Engagement}

Now, we would like to know more about the titles you hold in this village.

\begin{tabular}{|c|c|c|c|}
\hline QID & 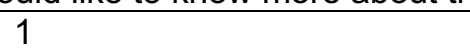 & 2 & 3 \\
\hline & $\begin{array}{l}\text { Have you hold a ,title" in this } \\
\text { village in the last } 12 \text { months? } \\
\text { (Code } A \text { ) }\end{array}$ & $\begin{array}{l}\text { If QID 1=1-9: Since when do } \\
\text { you hold this title? (Tahun) }\end{array}$ & $\begin{array}{l}\text { If QID } 1 \text { =1-9: Election } \\
\text { process? (Code B) }\end{array}$ \\
\hline & & & \\
\hline
\end{tabular}

Code A: (1)Kepala desa (2) Wakil kepala desa; (3) Sekertaris desa; (4) Kepala Dusun; (5) Kepala RT; (6) Kepala koperasi petani (7) Ketua kelompok petani; (8) Kepala (ketua) majlis taklim; (9) Sesepuh; (10) Kepala Imbarga adat (11) Ketua Karang Taruna; (12) Imam syarrat; (13) Mubaligh; (14) Kepala anggota politik (15) Hajis; (16) other, specify:

Code B: (1) inheritage; (2) appointed by kepala desa (3) elected by group; (4) elected by all villagers; (5) other, specify:

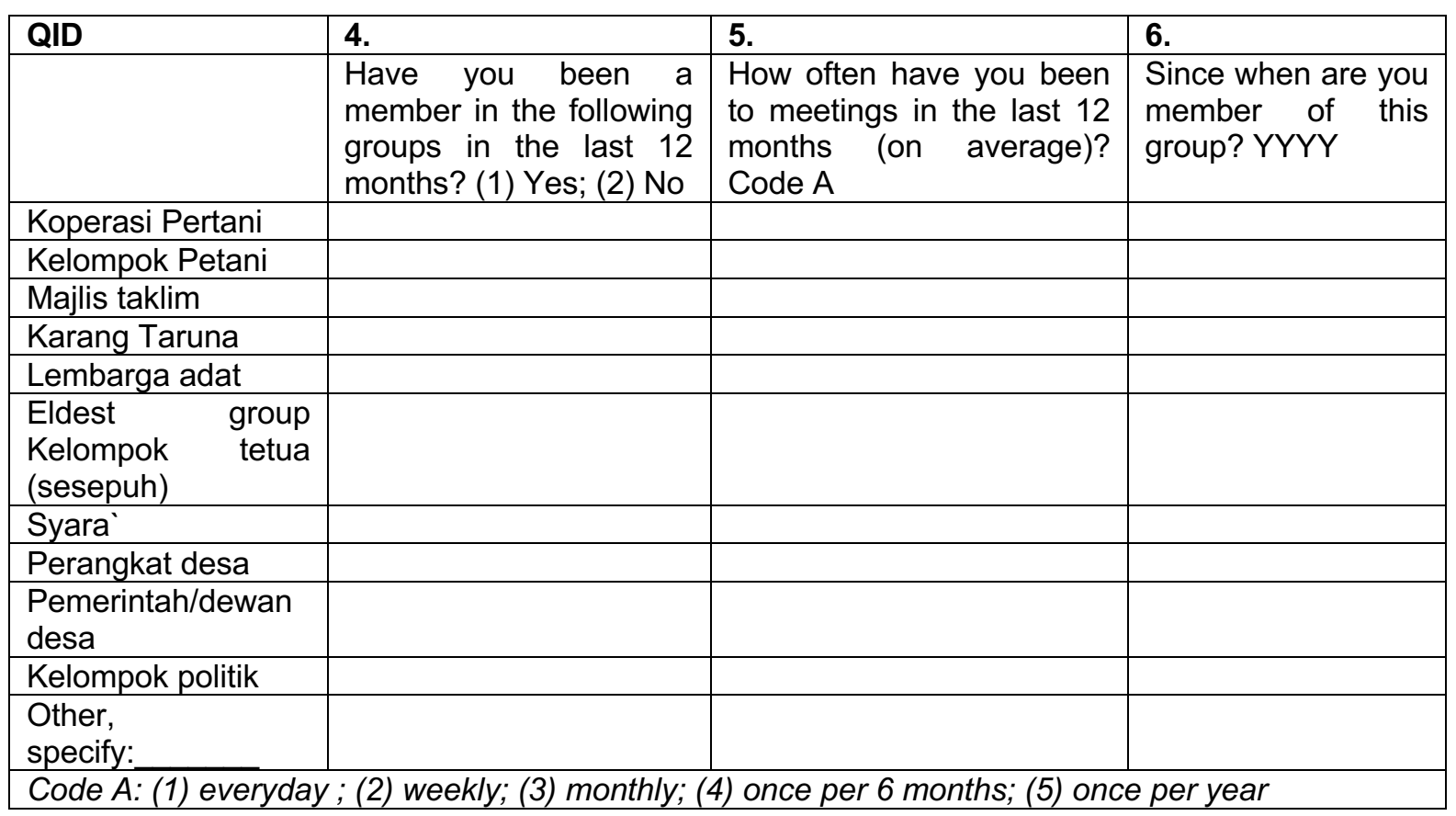

11. Environmental Perception

Which card reflects (the best) you relationship with the nature?

Number: 


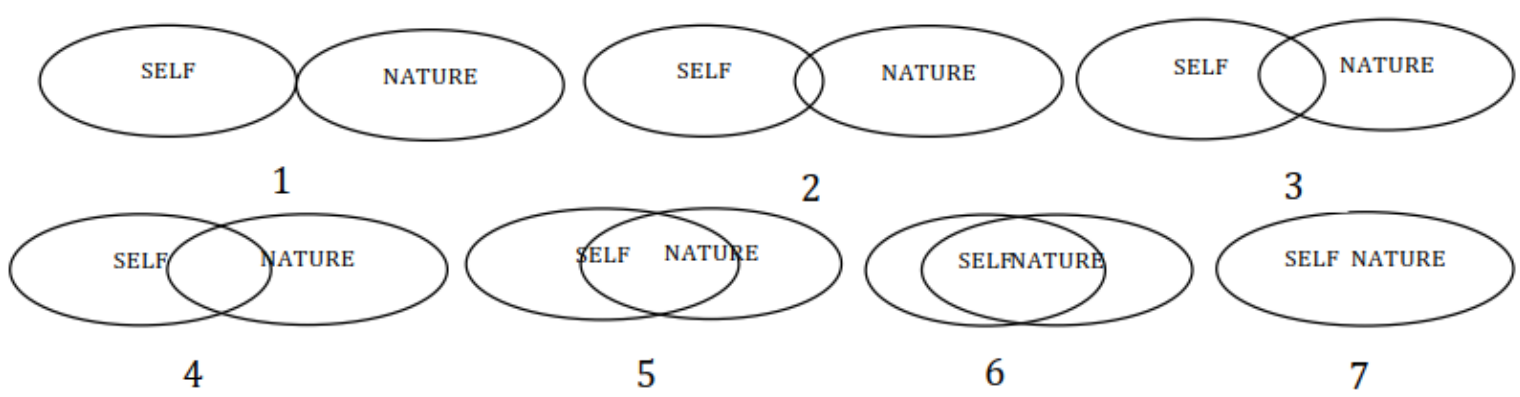

12. Perception (Oil palm, rubber plantation, Jungle rubber)

Here you can see three different production systems, which you might know (oil palm, rubber plantation, jungle rubber). Now, we are going to read out different question?

(1) Oil palm; (2) rubber plantation; (3) jungle rubber

\begin{tabular}{|l|l|l|l|l|}
\hline QID & \multicolumn{1}{|c|}{} & $1^{\text {st }}$ & $2^{\text {nd }}$ & 3th \\
\hline $\mathbf{1 .}$ & $\begin{array}{l}\text { Which of the production systems do you find most beautiful } \\
\text { (second most beautiful and third most beautiful)? }\end{array}$ & & \\
\hline $\mathbf{2 .}$ & $\begin{array}{l}\text { Which of the production systems do you find the most natural (the } \\
\text { second natural and the third natural)? }\end{array}$ & & & \\
\hline $\mathbf{3 .}$ & $\begin{array}{l}\text { Which of the production systems do you find the most profitable } \\
\text { (the second profitable and the third profitable)? }\end{array}$ & & & \\
\hline $\mathbf{4 .}$ & $\begin{array}{l}\text { Which of the production systems do you associate the most with } \\
\text { the improved wellbeing of your family (the second and the third)? }\end{array}$ & & \\
\hline $\mathbf{5 .}$ & $\begin{array}{l}\text { Which of the production systems do you associate the most with } \\
\text { decreasing number of birds and mammals (the second and the } \\
\text { third)? }\end{array}$ & $\begin{array}{l}\text { Which of the production systems do you associate the most with } \\
\text { increasing water scarcity (the second and the third)? }\end{array}$ & & \\
\hline $\mathbf{6 .}$ & $\begin{array}{l}\text { Which of the production systems do you associate the most with } \\
\text { decreasing nutrients in the soil (the second and the third)? }\end{array}$ & & \\
\hline $\mathbf{7 .}$
\end{tabular}

\section{Environmental events}

Over the last five years, was your household affected by the following events? How serious was your household affected by this event over last five years?

\begin{tabular}{|l|l|l|l|l|}
\hline QID & \multicolumn{3}{l|}{ Household was__affected by } \\
\hline & & Serious & Slightly & Not at all \\
\hline 1. & Drought/Water scarcity & & & \\
\hline 2. & Flood/too much rain & & & \\
\hline 3. & Crop diseases & & & \\
\hline 4. & Erosion & & & \\
\hline 5. & Decreasing soil fertility & & \\
\hline
\end{tabular}

\begin{tabular}{|l|l|l|l|}
\hline QID & Question & Answer & Code \\
\hline 6. & $\begin{array}{l}\text { Since you live in this village has the number of events } \\
\text { related to the environment (water scarcity; soil erosion; } \\
\text { drought; flooding) increased, decreased or stayed } \\
\text { constant? }\end{array}$ & $\begin{array}{l}\text { (1) increase; (2) } \\
\text { decrease; (3) stay } \\
\text { constant }\end{array}$ \\
\hline 7. & $\begin{array}{l}\text { Do you think environmental problems (erosion, floods, soil } \\
\text { fertility, and biodiversity loss) will become worse for your } \\
\text { village? }\end{array}$ & (1) Yes; (2) No \\
\hline
\end{tabular}

\section{Migration}


1. Has your household migrated from somewhere to this village? ( if 2 switch to QID 8)

2. If QID 1. =1, Did your household migrate as part of trans migrant program?

(1) Yes; (2) No

\begin{tabular}{|c|c|c|c|c|}
\hline 3. & 4. & 5. & 6. & 7. \\
\hline $\begin{array}{l}\text { Place from where the } \\
\text { household migrated } \\
\text { to this village? (Code } \\
\text { A) }\end{array}$ & $\begin{array}{l}\text { Year of } \\
\text { transmigratio } \\
\text { n/migration }\end{array}$ & $\begin{array}{l}\text { Since when } \\
\text { does your } \\
\mathrm{HH} \text { live in } \\
\text { this village }\end{array}$ & $\begin{array}{l}\text { Who was the head of } \\
\text { the household at time } \\
\text { of migration (code B) }\end{array}$ & $\begin{array}{l}\text { What was the major } \\
\text { source of income } \\
\text { before migration? }\end{array}$ \\
\hline \multicolumn{5}{|c|}{$\begin{array}{l}\text { Code A: (1) Jambi province ; (2) Java ; (3) Sumatera North ; (4) Sumatera South ; (5) Kaliman- } \\
\tan \text {; (6) Sulawesi ; (7) other, specify: }\end{array}$} \\
\hline $\begin{array}{l}\text { Code B: (1) current HH } \\
\text { rent HH head } \\
\text { specify: }\end{array}$ & $\begin{array}{l}\text { head, (2) fath } \\
\text { (4) other }\end{array}$ & $\begin{array}{l}\text { r/mother of } \mathrm{cu} \\
\text { relatives of }\end{array}$ & $\begin{array}{l}\text { rent HH head; (3) gran } \\
\text { current HH he }\end{array}$ & father of cur- \\
\hline
\end{tabular}

\begin{tabular}{|l|l|l|l|}
\hline QID & Question & Answer & Code \\
\hline 8. & What is your religion? & & $\begin{array}{l}\text { (1) Islam; (2) Hindu; (3) Protestan; (4) Katolik; (5) } \\
\text { Pantekosta; (6) Budha; (7) other, } \\
\text { specify: }\end{array}$ \\
\hline 9. & What is you ethnic? & $\begin{array}{l}\text { (1) Melayu; (2) Rimba; (3) Bugis; (4) Jawa; (5) Sunda; } \\
\text { (6) Batak; (7) Manado; (8) Minahasa; (9) Poso; (10) } \\
\text { Minang; (11) Bali; (12) Toraja; (13) Aceh; (14) Makasar; } \\
\text { (15) }\end{array}$ \\
\hline
\end{tabular}

\section{Final Questions}

We are going to read out some statements related to the distribution of land in your village. We would like to know your opinion. Therefore please use this scale (strongly agree-strongly disagree).

\begin{tabular}{|c|c|c|c|c|c|}
\hline QID & & $\begin{array}{l}\text { Strongly } \\
\text { Agree }\end{array}$ & Agree & Disagree & $\begin{array}{l}\text { Strongly } \\
\text { Disagree }\end{array}$ \\
\hline 1 & The purchase of land is often illegal & & & & \\
\hline 2 & $\begin{array}{l}\text { The amount of land that someone owns is a result } \\
\text { of heritage }\end{array}$ & & & & \\
\hline 3 & $\begin{array}{l}\text { The amount of land that someone own is a result } \\
\text { of hard work }\end{array}$ & & & & \\
\hline 4 & $\begin{array}{l}\text { The amount of land that someone own is a result } \\
\text { of luck }\end{array}$ & & & & \\
\hline 5 & Income should be made more equal & & & & \\
\hline 6 & $\begin{array}{l}\text { Hard work does not generally bring success- its } \\
\text { mor a matter of luck and connections }\end{array}$ & & & & \\
\hline 7 & People can only get rich at the expenses of others & & & & \\
\hline 8 & $\begin{array}{l}\text { Most people that are rich have worked very hard to } \\
\text { achieve this }\end{array}$ & & & & \\
\hline
\end{tabular}

\section{Thank you for your participation!}




\section{Appendix 7. Payoff table, per treatment and per endowment}

\section{A1. Payoff table - Individual scheme}

\begin{tabular}{|c|c|c|c|c|c|c|c|c|c|c|c|c|c|c|c|c|c|c|}
\hline \multicolumn{19}{|c|}{ No incentive scenario } \\
\hline \multicolumn{7}{|c|}{ Low-endowed } & \multicolumn{12}{|c|}{ High-endowed } \\
\hline & 0 & 1 & 2 & 3 & 4 & 5 & & 0 & 1 & 2 & 3 & 4 & 5 & 6 & 7 & 8 & 9 & 10 \\
\hline 0 & 5 & 4.5 & 4 & 3.5 & 3 & 2.5 & 0 & 10 & 9.6 & 9.2 & 8.8 & 8.4 & 8 & 7.6 & 7.2 & 6.8 & 6.4 & 6 \\
\hline 1 & 5.2 & 4.7 & 4.2 & 3.7 & 3.2 & 2.7 & 1 & 10.2 & 9.8 & 9.4 & 9 & 8.6 & 8.2 & 7.8 & 7.4 & 7 & 6.6 & 6.2 \\
\hline 2 & 5.4 & 4.9 & 4.4 & 3.9 & 3.4 & 2.9 & 2 & 10.4 & 10 & 9.6 & 9.2 & 8.8 & 8.4 & 8 & 7.6 & 7.2 & 6.8 & 6.4 \\
\hline 3 & 5.6 & 5.1 & 4.6 & 4.1 & 3.6 & 3.1 & 3 & 10.6 & 10.2 & 9.8 & 9.4 & 9 & 8.6 & 8.2 & 7.8 & 7.4 & 7 & 6.6 \\
\hline 4 & 5.8 & 5.3 & 4.8 & 4.3 & 3.8 & 3.3 & 4 & 10.8 & 10.4 & 10 & 9.6 & 9.2 & 8.8 & 8.4 & 8 & 7.6 & 7.2 & 6.8 \\
\hline 5 & 6 & 5.5 & 5 & 4.5 & 4 & 3.5 & 5 & 11 & 10.6 & 10.2 & 9.8 & 9.4 & 9 & 8.6 & 8.2 & 7.8 & 7.4 & 7 \\
\hline 6 & 6.2 & 5.7 & 5.2 & 4.7 & 4.2 & 3.7 & 6 & 11.2 & 10.8 & 10.4 & 10 & 9.6 & 9.2 & 8.8 & 8.4 & 8 & 7.6 & 7.2 \\
\hline 7 & 6.4 & 5.9 & 5.4 & 4.9 & 4.4 & 3.9 & 7 & 11.4 & 11 & 10.6 & 10.2 & 9.8 & 9.4 & 9 & 8.6 & 8.2 & 7.8 & 7.4 \\
\hline 8 & 6.6 & 6.1 & 5.6 & 5.1 & 4.6 & 4.1 & 8 & 11.6 & 11.2 & 10.8 & 10.4 & 10 & 9.6 & 9.2 & 8.8 & 8.4 & 8 & 7.6 \\
\hline 9 & 6.8 & 6.3 & 5.8 & 5.3 & 4.8 & 4.3 & 9 & 11.8 & 11.4 & 11 & 10.6 & 10.2 & 9.8 & 9.4 & 9 & 8.6 & 8.2 & 7.8 \\
\hline 10 & 7 & 6.5 & 6 & 5.5 & 5 & 4.5 & 10 & 12 & 11.6 & 11.2 & 10.8 & 10.4 & 10 & 9.6 & 9.2 & 8.8 & 8.4 & 8 \\
\hline
\end{tabular}

5\% Incentive

$\begin{array}{rrrrrrr} & 0 & 1 & 2 & 3 & 4 & 5 \\ 0 & 5 & 4.55 & 4.1 & 3.65 & 3.2 & 2.75 \\ 1 & 5.2 & 4.75 & 4.3 & 3.85 & 3.4 & 2.95 \\ 2 & 5.4 & 4.95 & 4.5 & 4.05 & 3.6 & 3.15 \\ 3 & 5.6 & 5.15 & 4.7 & 4.25 & 3.8 & 3.35 \\ 4 & 5.8 & 5.35 & 4.9 & 4.45 & 4 & 3.55 \\ 5 & 6 & 5.55 & 5.1 & 4.65 & 4.2 & 3.75 \\ 6 & 6.2 & 5.75 & 5.3 & 4.85 & 4.4 & 3.95 \\ 7 & 6.4 & 5.95 & 5.5 & 5.05 & 4.6 & 4.15 \\ 8 & 6.6 & 6.15 & 5.7 & 5.25 & 4.8 & 4.35 \\ 9 & 6.8 & 6.35 & 5.9 & 5.45 & 5 & 4.55 \\ 10 & 7 & 6.55 & 6.1 & 5.65 & 5.2 & 4.75 \\ 11 & 7.2 & 6.75 & 6.3 & 5.85 & 5.4 & 4.95 \\ 12 & 7.4 & 6.95 & 6.5 & 6.05 & 5.6 & 5.15 \\ 13 & 7.6 & 7.15 & 6.7 & 6.25 & 5.8 & 5.35 \\ 14 & 7.8 & 7.35 & 6.9 & 6.45 & 6 & 5.55 \\ 15 & 8 & 7.55 & 7.1 & 6.65 & 6.2 & 5.75\end{array}$

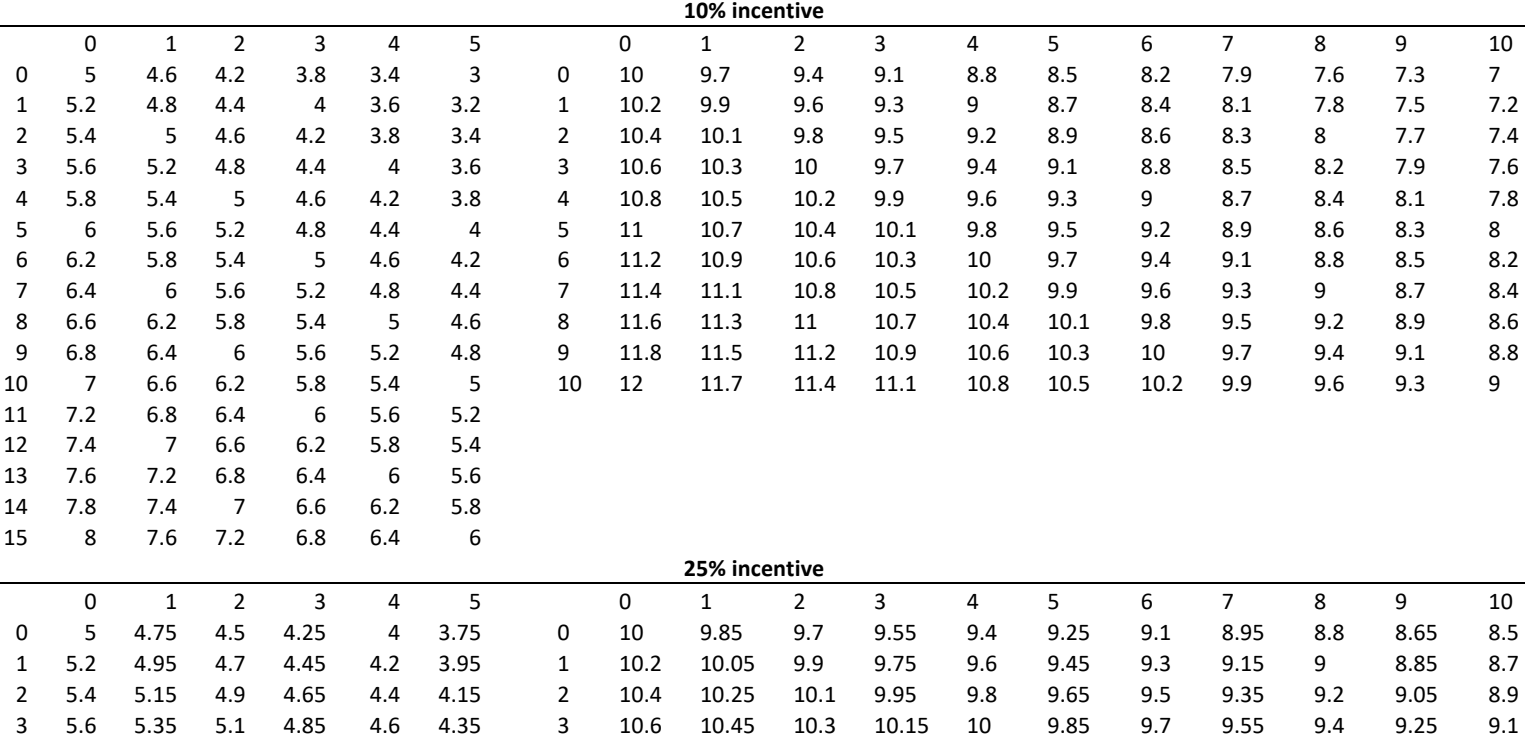




\begin{tabular}{|c|c|c|c|c|c|c|c|c|c|c|c|c|c|c|c|c|c|c|}
\hline 4 & 5.8 & 5.55 & 5.3 & 5.05 & 4.8 & 4.55 & 4 & 10.8 & 10.65 & 10.5 & 10.35 & 10.2 & 10.05 & 9.9 & 9.75 & 9.6 & 9.45 & 9.3 \\
\hline 5 & 6 & 5.75 & 5.5 & 5.25 & 5 & 4.75 & 5 & 11 & 10.85 & 10.7 & 10.55 & 10.4 & 10.25 & 10.1 & 9.95 & 9.8 & 9.65 & 9.5 \\
\hline 6 & 6.2 & 5.95 & 5.7 & 5.45 & 5.2 & 4.95 & 6 & 11.2 & 11.05 & 10.9 & 10.75 & 10.6 & 10.45 & 10.3 & 10.15 & 10 & 9.85 & 9.7 \\
\hline 7 & 6.4 & 6.15 & 5.9 & 5.65 & 5.4 & 5.15 & 7 & 11.4 & 11.25 & 11.1 & 10.95 & 10.8 & 10.65 & 10.5 & 10.35 & 10.2 & 10.05 & 9.9 \\
\hline 8 & 6.6 & 6.35 & 6.1 & 5.85 & 5.6 & 5.35 & 8 & 11.6 & 11.45 & 11.3 & 11.15 & 11 & 10.85 & 10.7 & 10.55 & 10.4 & 10.25 & 10.1 \\
\hline 9 & 6.8 & 6.55 & 6.3 & 6.05 & 5.8 & 5.55 & 9 & 11.8 & 11.65 & 11.5 & 11.35 & 11.2 & 11.05 & 10.9 & 10.75 & 10.6 & 10.45 & 10.3 \\
\hline 10 & 7 & 6.75 & 6.5 & 6.25 & 6 & 5.75 & 10 & 12 & 11.85 & 11.7 & 11.55 & 11.4 & 11.25 & 11.1 & 10.95 & 10.8 & 10.65 & 10.5 \\
\hline 11 & 7.2 & 6.95 & 6.7 & 6.45 & 6.2 & 5.95 & & & & & & & & & & & & \\
\hline 12 & 7.4 & 7.15 & 6.9 & 6.65 & 6.4 & 6.15 & & & & & & & & & & & & \\
\hline 13 & 7.6 & 7.35 & 7.1 & 6.85 & 6.6 & 6.35 & & & & & & & & & & & & \\
\hline 14 & 7.8 & 7.55 & 7.3 & 7.05 & 6.8 & 6.55 & & & & & & & & & & & & \\
\hline 15 & 8 & 7.75 & 7.5 & 7.25 & 7 & 6.75 & & & & & & & & & & & & \\
\hline \multicolumn{19}{|c|}{$30 \%$ incentive } \\
\hline & 0 & 1 & 2 & 3 & 4 & 5 & & 0 & 1 & 2 & 3 & 4 & 5 & 6 & 7 & 8 & 9 & 10 \\
\hline 0 & 5 & 4.8 & 4.6 & 4.4 & 4.2 & 4 & 0 & 10 & 9.9 & 9.8 & 9.7 & 9.6 & 9.5 & 9.4 & 9.3 & 9.2 & 9.1 & 9 \\
\hline 1 & 5.2 & 5 & 4.8 & 4.6 & 4.4 & 4.2 & 1 & 10.2 & 10.1 & 10 & 9.9 & 9.8 & 9.7 & 9.6 & 9.5 & 9.4 & 9.3 & 9.2 \\
\hline 2 & 5.4 & 5.2 & 5 & 4.8 & 4.6 & 4.4 & 2 & 10.4 & 10.3 & 10.2 & 10.1 & 10 & 9.9 & 9.8 & 9.7 & 9.6 & 9.5 & 9.4 \\
\hline 3 & 5.6 & 5.4 & 5.2 & 5 & 4.8 & 4.6 & 3 & 10.6 & 10.5 & 10.4 & 10.3 & 10.2 & 10.1 & 10 & 9.9 & 9.8 & 9.7 & 9.6 \\
\hline 4 & 5.8 & 5.6 & 5.4 & 5.2 & 5 & 4.8 & 4 & 10.8 & 10.7 & 10.6 & 10.5 & 10.4 & 10.3 & 10.2 & 10.1 & 10 & 9.9 & 9.8 \\
\hline 5 & 6 & 5.8 & 5.6 & 5.4 & 5.2 & 5 & 5 & 11 & 10.9 & 10.8 & 10.7 & 10.6 & 10.5 & 10.4 & 10.3 & 10.2 & 10.1 & 10 \\
\hline 6 & 6.2 & 6 & 5.8 & 5.6 & 5.4 & 5.2 & 6 & 11.2 & 11.1 & 11 & 10.9 & 10.8 & 10.7 & 10.6 & 10.5 & 10.4 & 10.3 & 10.2 \\
\hline 7 & 6.4 & 6.2 & 6 & 5.8 & 5.6 & 5.4 & 7 & 11.4 & 11.3 & 11.2 & 11.1 & 11 & 10.9 & 10.8 & 10.7 & 10.6 & 10.5 & 10.4 \\
\hline 8 & 6.6 & 6.4 & 6.2 & 6 & 5.8 & 5.6 & 8 & 11.6 & 11.5 & 11.4 & 11.3 & 11.2 & 11.1 & 11 & 10.9 & 10.8 & 10.7 & 10.6 \\
\hline 9 & 6.8 & 6.6 & 6.4 & 6.2 & 6 & 5.8 & 9 & 11.8 & 11.7 & 11.6 & 11.5 & 11.4 & 11.3 & 11.2 & 11.1 & 11 & 10.9 & 10.8 \\
\hline 10 & 7 & 6.8 & 6.6 & 6.4 & 6.2 & 6 & 10 & 12 & 11.9 & 11.8 & 11.7 & 11.6 & 11.5 & 11.4 & 11.3 & 11.2 & 11.1 & 11 \\
\hline 11 & 7.2 & 7 & 6.8 & 6.6 & 6.4 & 6.2 & & & & & & & & & & & & \\
\hline 12 & 7.4 & 7.2 & 7 & 6.8 & 6.6 & 6.4 & & & & & & & & & & & & \\
\hline 13 & 7.6 & 7.4 & 7.2 & 7 & 6.8 & 6.6 & & & & & & & & & & & & \\
\hline 14 & 7.8 & 7.6 & 7.4 & 7.2 & 7 & 6.8 & & & & & & & & & & & & \\
\hline 15 & 8 & 7.8 & 7.6 & 7.4 & 7.2 & 7 & & & & & & & & & & & & \\
\hline
\end{tabular}

\section{A2. Payoff table - Collective scheme}

\begin{tabular}{|c|c|c|c|c|c|c|c|c|c|c|c|c|c|c|c|c|c|c|}
\hline \multicolumn{19}{|c|}{$5 \%$ incentives } \\
\hline \multicolumn{7}{|c|}{ Low-endowed } & \multicolumn{12}{|c|}{ High-endowed } \\
\hline & 0 & 1 & 2 & 3 & 4 & 5 & & 0 & 1 & 2 & 3 & 4 & 5 & 6 & 7 & 8 & 9 & 10 \\
\hline 0 & 5 & 4.5 & 4 & 3.5 & 3 & 2.5 & 0 & 10 & 9.6 & 9.2 & 8.8 & 8.4 & 8 & 7.6 & 7.55 & 7.2 & 6.85 & 6.5 \\
\hline 1 & 5.2 & 4.7 & 4.2 & 3.7 & 3.2 & 2.7 & 1 & 10.2 & 9.8 & 9.4 & 9 & 8.6 & 8.2 & 8.1 & 7.75 & 7.4 & 7.05 & 6.7 \\
\hline 2 & 5.4 & 4.9 & 4.4 & 3.9 & 3.4 & 3.15 & 2 & 10.4 & 10 & 9.6 & 9.2 & 8.8 & 8.65 & 8.3 & 7.95 & 7.6 & 7.25 & 6.9 \\
\hline 3 & 5.6 & 5.1 & 4.6 & 4.1 & 3.8 & 3.35 & 3 & 10.6 & 10.2 & 9.8 & 9.4 & 9.2 & 8.85 & 8.5 & 8.15 & 7.8 & 7.45 & 7.1 \\
\hline 4 & 5.8 & 5.3 & 4.8 & 4.45 & 4 & 3.55 & 4 & 10.8 & 10.4 & 10 & 9.75 & 9.4 & 9.05 & 8.7 & 8.35 & 8 & 7.65 & 7.3 \\
\hline 5 & 6 & 5.5 & 5.1 & 4.65 & 4.2 & 3.75 & 5 & 11 & 10.6 & 10.3 & 9.95 & 9.6 & 9.25 & 8.9 & 8.55 & 8.2 & 7.85 & 7.5 \\
\hline 6 & 6.2 & 5.75 & 5.3 & 4.85 & 4.4 & 3.95 & 6 & 11.2 & 10.85 & 10.5 & 10.15 & 9.8 & 9.45 & 9.1 & 8.75 & 8.4 & 8.05 & 7.7 \\
\hline 7 & 6.4 & 5.95 & 5.5 & 5.05 & 4.6 & 4.15 & 7 & 11.4 & 11.05 & 10.7 & 10.35 & 10 & 9.65 & 9.3 & 8.95 & 8.6 & 8.25 & 7.9 \\
\hline 8 & 6.6 & 6.15 & 5.7 & 5.25 & 4.8 & 4.35 & 8 & 11.6 & 11.25 & 10.9 & 10.55 & 10.2 & 9.85 & 9.5 & 9.15 & 8.8 & 8.45 & 8.1 \\
\hline 9 & 6.8 & 6.35 & 5.9 & 5.45 & 5 & 4.55 & 9 & 11.8 & 11.45 & 11.1 & 10.75 & 10.4 & 10.05 & 9.7 & 9.35 & 9 & 8.65 & 8.3 \\
\hline 10 & 7 & 6.55 & 6.1 & 5.65 & 5.2 & 4.75 & 10 & 12 & 11.65 & 11.3 & 10.95 & 10.6 & 10.25 & 9.9 & 9.55 & 9.2 & 8.85 & 8.5 \\
\hline 11 & 7.2 & 6.75 & 6.3 & 5.85 & 5.4 & 4.95 & & & & & & & & & & & & \\
\hline 12 & 7.4 & 6.95 & 6.5 & 6.05 & 5.6 & 5.15 & & & & & & & & & & & & \\
\hline 13 & 7.6 & 7.15 & 6.7 & 6.25 & 5.8 & 5.35 & & & & & & & & & & & & \\
\hline 14 & 7.8 & 7.35 & 6.9 & 6.45 & 6 & 5.55 & & & & & & & & & & & & \\
\hline 15 & 8 & 7.55 & 7.1 & 6.65 & 6.2 & 5.75 & & & & & & & & & & & & \\
\hline
\end{tabular}

\begin{tabular}{|c|c|c|c|c|c|c|c|c|c|c|c|c|c|c|c|c|c|c|}
\hline \multicolumn{19}{|c|}{$10 \%$ incentives } \\
\hline & 0 & 1 & 2 & 3 & 4 & 5 & & 0 & 1 & 2 & 3 & 4 & 5 & 6 & 7 & 8 & 9 & 10 \\
\hline 0 & 5 & 4.5 & 4 & 3.5 & 3 & 2.5 & 0 & 10 & 9.6 & 9.2 & 8.8 & 8.4 & 8 & 7.6 & 7.9 & 7.6 & 7.3 & 7 \\
\hline 1 & 5.2 & 4.7 & 4.2 & 3.7 & 3.2 & 2.7 & 1 & 10.2 & 9.8 & 9.4 & 9 & 8.6 & 8.2 & 8.4 & 8.1 & 7.8 & 7.5 & 7.2 \\
\hline 2 & 5.4 & 4.9 & 4.4 & 3.9 & 3.4 & 3.4 & 2 & 10.4 & 10 & 9.6 & 9.2 & 8.8 & 8.9 & 8.6 & 8.3 & 8 & 7.7 & 7.4 \\
\hline 3 & 5.6 & 5.1 & 4.6 & 4.1 & 4 & 3.6 & 3 & 10.6 & 10.2 & 9.8 & 9.4 & 9.4 & 9.1 & 8.8 & 8.5 & 8.2 & 7.9 & 7.6 \\
\hline 4 & 5.8 & 5.3 & 4.8 & 4.6 & 4.2 & 3.8 & 4 & 10.8 & 10.4 & 10 & 9.9 & 9.6 & 9.3 & 9 & 8.7 & 8.4 & 8.1 & 7.8 \\
\hline 5 & 6 & 5.5 & 5.2 & 4.8 & 4.4 & 4 & 5 & 11 & 10.6 & 10.4 & 10.1 & 9.8 & 9.5 & 9.2 & 8.9 & 8.6 & 8.3 & 8 \\
\hline 6 & 6.2 & 5.8 & 5.4 & 5 & 4.6 & 4.2 & 6 & 11.2 & 10.9 & 10.6 & 10.3 & 10 & 9.7 & 9.4 & 9.1 & 8.8 & 8.5 & 8.2 \\
\hline 7 & 6.4 & 6 & 5.6 & 5.2 & 4.8 & 4.4 & 7 & 11.4 & 11.1 & 10.8 & 10.5 & 10.2 & 9.9 & 9.6 & 9.3 & 9 & 8.7 & 8.4 \\
\hline 8 & 6.6 & 6.2 & 5.8 & 5.4 & 5 & 4.6 & 8 & 11.6 & 11.3 & 11 & 10.7 & 10.4 & 10.1 & 9.8 & 9.5 & 9.2 & 8.9 & 8.6 \\
\hline 9 & 6.8 & 6.4 & 6 & 5.6 & 5.2 & 4.8 & 9 & 11.8 & 11.5 & 11.2 & 10.9 & 10.6 & 10.3 & 10 & 9.7 & 9.4 & 9.1 & 8.8 \\
\hline 10 & 7 & 6.6 & 6.2 & 5.8 & 5.4 & 5 & 10 & 12 & 11.7 & 11.4 & 11.1 & 10.8 & 10.5 & 10.2 & 9.9 & 9.6 & 9.3 & 9 \\
\hline 11 & 7.2 & 6.8 & 6.4 & 6 & 5.6 & 5.2 & & & & & & & & & & & & \\
\hline 12 & 7.4 & 7 & 6.6 & 6.2 & 5.8 & 5.4 & & & & & & & & & & & & \\
\hline 13 & 7.6 & 7.2 & 6.8 & 6.4 & 6 & 5.6 & & & & & & & & & & & & \\
\hline 14 & 7.8 & 7.4 & 7 & 6.6 & 6.2 & 5.8 & & & & & & & & & & & & \\
\hline 15 & 8 & 7.6 & 7.2 & 6.8 & 6.4 & 6 & & & & & & & & & & & & \\
\hline \multicolumn{19}{|c|}{$25 \%$ incentives } \\
\hline & 0 & 1 & 2 & 3 & 4 & 5 & & 0 & 1 & 2 & 3 & 4 & 5 & 6 & 7 & 8 & 9 & 10 \\
\hline 0 & 5 & 4.5 & 4 & 3.5 & 3 & 2.5 & 0 & 10 & 9.6 & 9.2 & 8.8 & 8.4 & 8 & 7.6 & 8.95 & 8.8 & 8.65 & 8.5 \\
\hline
\end{tabular}




\begin{tabular}{|c|c|c|c|c|c|c|c|c|c|c|c|c|c|c|c|c|c|c|}
\hline 1 & 5.2 & 4.7 & 4.2 & 3.7 & 3.2 & 2.7 & 1 & 10.2 & 9.8 & 9.4 & 9 & 8.6 & 8.2 & 9.3 & 9.15 & 9 & 8.85 & 8.7 \\
\hline 2 & 5.4 & 4.9 & 4.4 & 3.9 & 3.4 & 4.15 & 2 & 10.4 & 10 & 9.6 & 9.2 & 8.8 & 9.65 & 9.5 & 9.35 & 9.2 & 9.05 & 8.9 \\
\hline 3 & 5.6 & 5.1 & 4.6 & 4.1 & 4.6 & 4.35 & 3 & 10.6 & 10.2 & 9.8 & 9.4 & 10 & 9.85 & 9.7 & 9.55 & 9.4 & 9.25 & 9.1 \\
\hline 4 & 5.8 & 5.3 & 4.8 & 5.05 & 4.8 & 4.55 & 4 & 10.8 & 10.4 & 10 & 10.35 & 10.2 & 10.05 & 9.9 & 9.75 & 9.6 & 9.45 & 9.3 \\
\hline 5 & 6 & 5.5 & 5.5 & 5.25 & 5 & 4.75 & 5 & 11 & 10.6 & 10.7 & 10.55 & 10.4 & 10.25 & 10.1 & 9.95 & 9.8 & 9.65 & 9.5 \\
\hline 6 & 6.2 & 5.95 & 5.7 & 5.45 & 5.2 & 4.95 & 6 & 11.2 & 11.05 & 10.9 & 10.75 & 10.6 & 10.45 & 10.3 & 10.15 & 10 & 9.85 & 9.7 \\
\hline 7 & 6.4 & 6.15 & 5.9 & 5.65 & 5.4 & 5.15 & 7 & 11.4 & 11.25 & 11.1 & 10.95 & 10.8 & 10.65 & 10.5 & 10.35 & 10.2 & 10.05 & 9.9 \\
\hline 8 & 6.6 & 6.35 & 6.1 & 5.85 & 5.6 & 5.35 & 8 & 11.6 & 11.45 & 11.3 & 11.15 & 11 & 10.85 & 10.7 & 10.55 & 10.4 & 10.25 & 10.1 \\
\hline 9 & 6.8 & 6.55 & 6.3 & 6.05 & 5.8 & 5.55 & 9 & 11.8 & 11.65 & 11.5 & 11.35 & 11.2 & 11.05 & 10.9 & 10.75 & 10.6 & 10.45 & 10.3 \\
\hline 10 & 7 & 6.75 & 6.5 & 6.25 & 6 & 5.75 & 10 & 12 & 11.85 & 11.7 & 11.55 & 11.4 & 11.25 & 11.1 & 10.95 & 10.8 & 10.65 & 10.5 \\
\hline 11 & 7.2 & 6.95 & 6.7 & 6.45 & 6.2 & 5.95 & & & & & & & & & & & & \\
\hline 12 & 7.4 & 7.15 & 6.9 & 6.65 & 6.4 & 6.15 & & & & & & & & & & & & \\
\hline 13 & 7.6 & 7.35 & 7.1 & 6.85 & 6.6 & 6.35 & & & & & & & & & & & & \\
\hline 14 & 7.8 & 7.55 & 7.3 & 7.05 & 6.8 & 6.55 & & & & & & & & & & & & \\
\hline 15 & 8 & 7.75 & 7.5 & 7.25 & 7 & 6.75 & & & & & & & & & & & & \\
\hline \multicolumn{19}{|c|}{$30 \%$ incentives } \\
\hline & 0 & 1 & 2 & 3 & 4 & 5 & & 0 & 1 & 2 & 3 & 4 & 5 & 6 & 7 & 8 & 9 & 10 \\
\hline 0 & 5 & 4.5 & 4 & 3.5 & 3 & 2.5 & 0 & 10 & 9.6 & 9.2 & 8.8 & 8.4 & 8 & 7.6 & 9.3 & 9.2 & 9.1 & 9 \\
\hline 1 & 5.2 & 4.7 & 4.2 & 3.7 & 3.2 & 2.7 & 1 & 10.2 & 9.8 & 9.4 & 9 & 8.6 & 8.2 & 9.6 & 9.5 & 9.4 & 9.3 & 9.2 \\
\hline 2 & 5.4 & 4.9 & 4.4 & 3.9 & 3.4 & 4.4 & 2 & 10.4 & 10 & 9.6 & 9.2 & 8.8 & 9.9 & 9.8 & 9.7 & 9.6 & 9.5 & 9.4 \\
\hline 3 & 5.6 & 5.1 & 4.6 & 4.1 & 4.8 & 4.6 & 3 & 10.6 & 10.2 & 9.8 & 9.4 & 10.2 & 10.1 & 10 & 9.9 & 9.8 & 9.7 & 9.6 \\
\hline 4 & 5.8 & 5.3 & 4.8 & 5.2 & 5 & 4.8 & 4 & 10.8 & 10.4 & 10 & 10.5 & 10.4 & 10.3 & 10.2 & 10.1 & 10 & 9.9 & 9.8 \\
\hline 5 & 6 & 5.5 & 5.6 & 5.4 & 5.2 & 5 & 5 & 11 & 10.6 & 10.8 & 10.7 & 10.6 & 10.5 & 10.4 & 10.3 & 10.2 & 10.1 & 10 \\
\hline 6 & 6.2 & 6 & 5.8 & 5.6 & 5.4 & 5.2 & 6 & 11.2 & 11.1 & 11 & 10.9 & 10.8 & 10.7 & 10.6 & 10.5 & 10.4 & 10.3 & 10.2 \\
\hline 7 & 6.4 & 6.2 & 6 & 5.8 & 5.6 & 5.4 & 7 & 11.4 & 11.3 & 11.2 & 11.1 & 11 & 10.9 & 10.8 & 10.7 & 10.6 & 10.5 & 10.4 \\
\hline 8 & 6.6 & 6.4 & 6.2 & 6 & 5.8 & 5.6 & 8 & 11.6 & 11.5 & 11.4 & 11.3 & 11.2 & 11.1 & 11 & 10.9 & 10.8 & 10.7 & 10.6 \\
\hline 9 & 6.8 & 6.6 & 6.4 & 6.2 & 6 & 5.8 & 9 & 11.8 & 11.7 & 11.6 & 11.5 & 11.4 & 11.3 & 11.2 & 11.1 & 11 & 10.9 & 10.8 \\
\hline 10 & 7 & 6.8 & 6.6 & 6.4 & 6.2 & 6 & 10 & 12 & 11.9 & 11.8 & 11.7 & 11.6 & 11.5 & 11.4 & 11.3 & 11.2 & 11.1 & 11 \\
\hline 11 & 7.2 & 7 & 6.8 & 6.6 & 6.4 & 6.2 & & & & & & & & & & & & \\
\hline 12 & 7.4 & 7.2 & 7 & 6.8 & 6.6 & 6.4 & & & & & & & & & & & & \\
\hline 13 & 7.6 & 7.4 & 7.2 & 7 & 6.8 & 6.6 & & & & & & & & & & & & \\
\hline 14 & 7.8 & 7.6 & 7.4 & 7.2 & 7 & 6.8 & & & & & & & & & & & & \\
\hline 15 & 8 & 7.8 & 7.6 & 7.4 & 7.2 & 7 & & & & & & & & & & & & \\
\hline
\end{tabular}




\section{Appendix 8. Correlation among social capital variables}

\begin{tabular}{|c|c|c|c|c|c|c|c|c|c|c|c|c|}
\hline & $\begin{array}{l}\text { Share of } \\
\text { rubber }\end{array}$ & Treatment & Incentive & Endowment & $\begin{array}{c}\text { Previous } \\
\text { cultivation } \\
\text { with rubber } \\
\text { agroforestry }\end{array}$ & $\begin{array}{l}\text { Education } \\
\text { of the } \\
\text { network }\end{array}$ & $\begin{array}{l}\text { Environmental } \\
\text { concern of the } \\
\text { network }\end{array}$ & $\begin{array}{c}\text { People from } \\
\text { the network } \\
\text { known that } \\
\text { cultivates } \\
\text { rubber } \\
\text { agroforestry }\end{array}$ & $\begin{array}{c}\text { People from } \\
\text { the network } \\
\text { known that } \\
\text { cultivates oil } \\
\text { palm }\end{array}$ & $\begin{array}{l}\text { Family members } \\
\text { participating in } \\
\text { the same } \\
\text { session }\end{array}$ & $\begin{array}{l}\text { People known } \\
\text { by name } \\
\text { participating in } \\
\text { the same } \\
\text { sessions }\end{array}$ & $\begin{array}{l}\text { People in the } \\
\text { same session with } \\
\text { whom they speak } \\
\text { in a month }\end{array}$ \\
\hline Share of rubber & 1.00 & & & & & & & & & & & \\
\hline Treatment & 0.02 & 1.00 & & & & & & & & & & \\
\hline Incentive & $0.07^{*}$ & 0.00 & 1.00 & & & & & & & & & \\
\hline Endowment & 0.02 & 0.00 & 0.00 & 1.00 & & & & & & & & \\
\hline $\begin{array}{l}\text { Previous } \\
\text { cultivation with } \\
\text { rubber } \\
\text { agroforestry }\end{array}$ & $0.07^{*}$ & 0.01 & 0.01 & -0.09 & 1.00 & & & & & & & \\
\hline $\begin{array}{l}\text { Education of the } \\
\text { network }\end{array}$ & $0.10^{* *}$ & -0.03 & -0.01 & -0.01 & -0.09 & 1.00 & & & & & & \\
\hline $\begin{array}{l}\text { Environmental } \\
\text { concern of the } \\
\text { network }\end{array}$ & 0.04 & 0.05 & -0.00 & -0.13 & 0.06 & 0.02 & 1.00 & & & & & \\
\hline $\begin{array}{l}\text { People from the } \\
\text { network known } \\
\text { that cultivates } \\
\text { rubber } \\
\text { agroforestry }\end{array}$ & 0.06 & 0.01 & -0.02 & -0.01 & -0.15 & 0.20 & 0.04 & 1.00 & & & & \\
\hline $\begin{array}{l}\text { People from the } \\
\text { network known } \\
\text { that cultivates oil } \\
\text { palm }\end{array}$ & -0.11 & -0.02 & 0.02 & -0.02 & 0.08 & 0.02 & 0.22 & 0.34 & 1.00 & & & \\
\hline $\begin{array}{l}\text { Family members } \\
\text { participating in } \\
\text { the same session }\end{array}$ & 0.03 & -0.11 & 0.02 & -0.03 & 0.25 & -0.04 & -0.02 & -0.44 & 0.16 & 1.00 & & \\
\hline $\begin{array}{l}\text { People known by } \\
\text { name } \\
\text { participating in } \\
\text { the same } \\
\text { sessions }\end{array}$ & -0.02 & -0.21 & 0.01 & 0.08 & 0.04 & 0.05 & -0.02 & 0.09 & 0.22 & 0.14 & 1.00 & \\
\hline $\begin{array}{l}\text { People in the } \\
\text { same session } \\
\text { with whom they } \\
\text { speak in a month }\end{array}$ & 0.00 & -0.10 & -0.01 & -0.02 & 0.10 & 0.04 & -0.00 & 0.11 & 0.05 & -0.04 & 0.27 & 1.00 \\
\hline
\end{tabular}


